PNL-3753

UC-95f

\title{
Chemical Production From Industrial Byproduct Gases: Final Report
}

\author{
S. E. Lyke \\ R. H. Moore
}

April 1981

Prepared for the U.S. Department of Energy under Contract DE-AC06-76RLO 1830

Pacific Northwest Laboratory

Operated for the U.S. Department of Energy

by Battelle Memorial Institute 
NOTICE

This report was prepared as an account of work sponsored by the United States Government. Neither the United States nor the Department of Energy, nor any of their employees, nor any of their contractors, subcontractors, or their employees, makes any warranty, express or implied, or assumes any legal liability or responsibility for the accuracy, completeness or usefulness of any information, apparatus, product or process disclosed, or represents that its use would not infringe privately owned rights.

The views, opinions and conclusions contained in this report are those of the contractor and do not necessarily represent those of the United States Government or the United States Department of Energy.

\author{
PACIFIC NORTHWEST LABORATORY \\ operated by \\ BATTELLE \\ for the \\ UNITED STATES DEPARTMENT OF ENERGY \\ Under Contract DE-AC06-76RLO 1830
}
Printed in the United States of America Available from
National Technical Information Service United States Department of Commerce
5285 Port Royal Road
Springfield, Virginia 22151

Price: Printed Copy $\$$ $\therefore$ Microfiche $\$ 3.00$

$\begin{array}{cr}\text { •Pages } & \text { Selling Price } \\ & \\ 001-025 & \$ 4.00 \\ 026-050 & \$ 4.50 \\ 051-075 & \$ 5.25 \\ 076-100 & \$ 6.00 \\ 101-125 & \$ 6.50 \\ 126-150 & \$ 7.25 \\ 151-175 & \$ 8.00 \\ 176-200 & \$ 9.00 \\ 201-225 & \$ 9.25 \\ 226-250 & \$ 9.50 \\ 251-275 & \$ 10.75 \\ 276-300 & \$ 11.00\end{array}$


CHEMICAL PRODUCTION FROM INDUSTRIAL BYPRODUCT GASES: FINAL REPORT

\author{
S. E. Lyke \\ R. H. Moore
}

Apri1 1981

Prepared for

the U.S. Department of Energy under Contract DE-ACO6-76RLO 1830

Pacific Northwest Laboratory

Richland, Washington 99352 


\section{SUMMARY}

The Pacific Northwest Laboratory has studied the concept of using industrial byproduct gases for chemical production. Several industrial operations produce carbon monoxide $(\mathrm{CO})$ and hydrogen $\left(\mathrm{H}_{2}\right)$ in byproduct gases, which are wasted or used as fuel. The chemical industry uses carbon monoxide and hydrogen, obtained from steam reforming of natural gas, in the production of several major chemicals. Using carbon monoxide and hydrogen from byproduct gases to produce these chemicals replaces the natural gas and the energy-intensive reforming step. The purpose of the study was to identify the potential for conservation of natural gas, determine the technical and economic feasibility, and facilitate the implementation of ventures to produce such chemicals using carbon monoxide and hydrogen from byproduct gases.

A survey was performed of potential chemical products and byproduct gas sources. Byproduct gases from the elemental phosphorus and the iron and steel industries were selected for detailed study. Gas sampling, preliminary design, market surveys and economic anlyses were performed for specific sources in the selected industries.

Sufficient byproduct gases and potential chemical applications exist in the United States to allow substantial conservation of natural gas by using byproduct carbon monoxide and hydrogen in chemical production. The study showed that production of methanol or ammonia from byproduct gas at the sites studied in the elemental phosphorus and the iron and steel industries is technically feasible but not economically viable under current conditions. Several other applications are identified in the report as having the potential for better economics. Determination of their feasibility will require case by case study. Producers of byproduct gases that could be used in those applications can determine feasibility through communication with appropriate personnel in the chemical industry.

The survey performed for this study identified a need for an improved method of recovering carbon monoxide from dilute gases. A modest experimental program was directed toward the development of a permselective membrane to fulfill that need. A practical membrane was not developed but further investigation along the same lines is recommended. 


\section{ACKNOWLEDGMENTS}

The exchange of information between industries that otherwise may not be in contact with one another formed the basis for this project. The authors gratefully acknowledge the assistance of numerous individuals in several industries who provided valuable information. The extensive cooperation of the Monsanto Company and of Kaiser Steel, Inc. is particularly acknowledged and special appreciation is extended to H. M. McKelvy and F. W. Thomas of Monsanto and to S. P. Vitt of Kaiser Steel. In addition, the authors extend their sincere appreciation to Dr. Jerome F. Collins, U.S. Department of Energy Office of Industrial Programs Project Manager, for his sustaining support and direction throughout this project. 
SUMMARY

ACKNOWLEDGMENTS

INTRODUCTION

CONCLUSIONS AND RECOMMENDATIONS

SELECTION OF CASES FOR STUDY

BYPRODUCT GAS SOURCES

POTENTIAL PRODUCTS

BASIS FOR SELECTION .

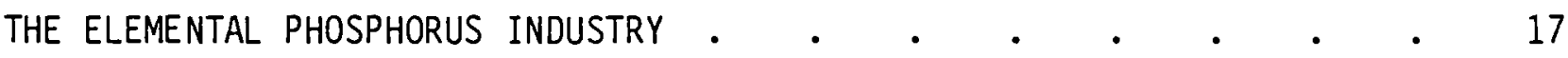

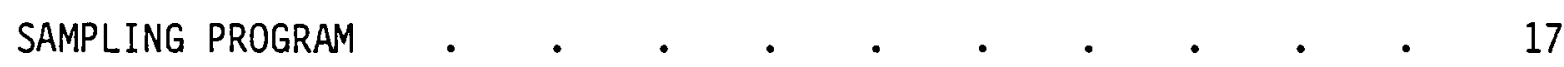

METHANOL STUDY •

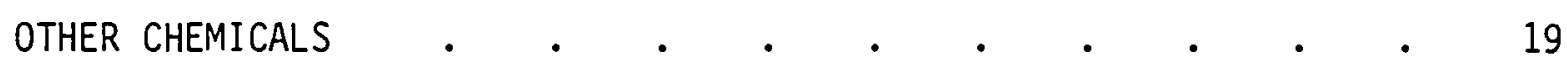

OUTLOOK

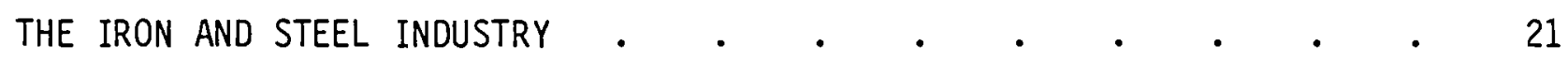

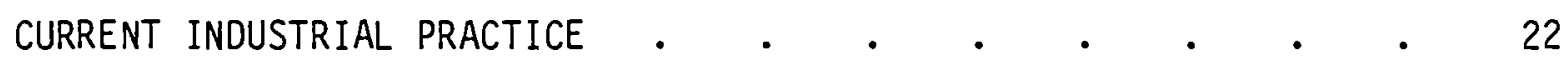

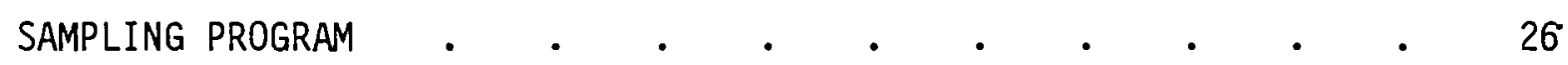

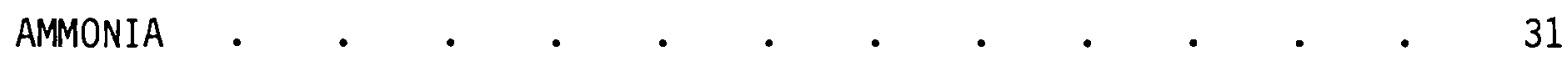

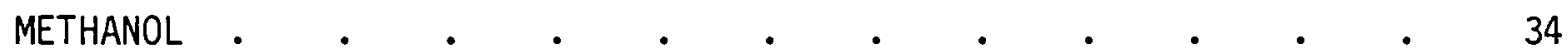

HYDROGEN •

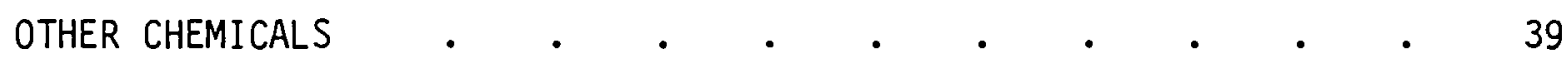

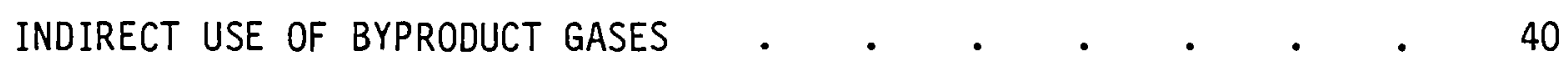

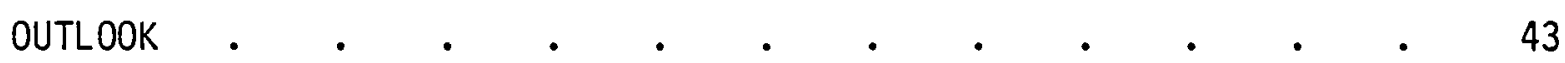


CARBON MONOXIDE SEPARATION FROM GAS STREAMS VIA

PERMSELECTIVE MEMBRANES

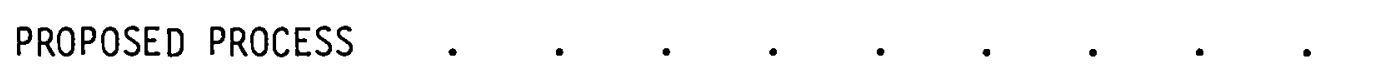

MEMBRANE PREPARATION AND EVALUATION $\quad . \quad \ldots \quad . \quad . \quad . \quad . \quad 52$

Polymer and Complex Preparation . . . . . . 52

Membrane Testing Equipment . . . . . . . 53

Membrane Preparation $\quad . \quad$. $\quad . \quad$. $\quad . \quad$. 55

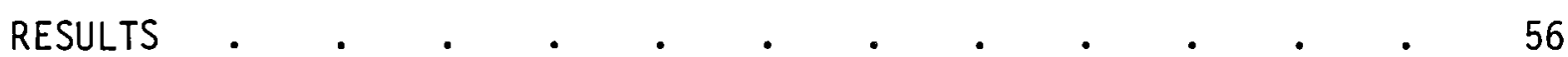

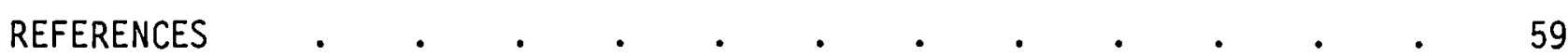

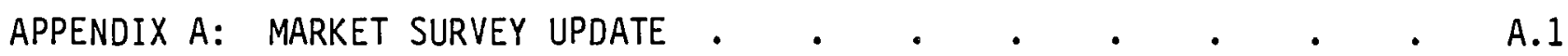

APPENDIX B: CHARACTERIZATION OF A TYPICAL ELEMENTAL

PHOSPHORUS BYPRODUCT GAS.$\quad \cdot \quad \cdot \quad \cdot \quad \cdot \quad \cdot \quad \cdot \quad \cdot \quad$ B.I

APPENDIX C: INDUSTRIAL OFF-GAS UTILIZATION DATA COLLECTION

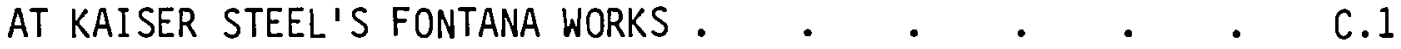




\section{FIGURES}

1 Compression Energy for Feed Gas to CO Separation . . . . . 13

2 Minimum Energy Required to Separate CO from a Mixture of Gases at Constant Temperature and Pressure . . . . . 14

3 Basic Oxygen Process Off-Gas Recovery System . . . . . . 25

4 Off-Gas Concentrations, Basic 0xygen Furnace \#6,

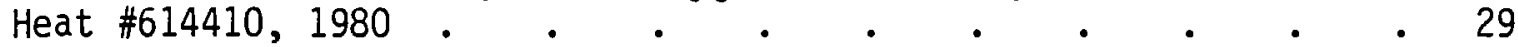

5 Off-Gas Concentrations Basic 0xygen Furnace \#5

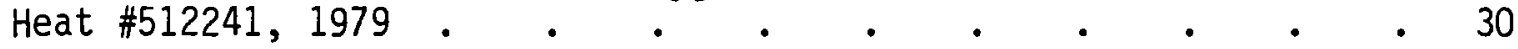

6 Ammonia from Coke-Oven Gas and Purchased Nitrogen . . . . 32

7 Ammonia From Coke-Oven, Basic Oxygen Process and

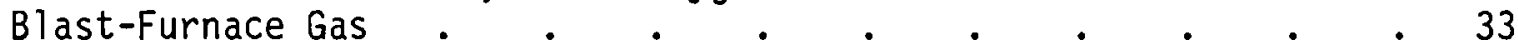

8 Methanol from Basic 0xygen Process and Coke-Oven Gas . • 35

9 Hydrogen Production from Coke-Oven Gas: Flow Diagram . • . 37

10 Use of Basic Oxygen Process Off Gas to Supply Heat

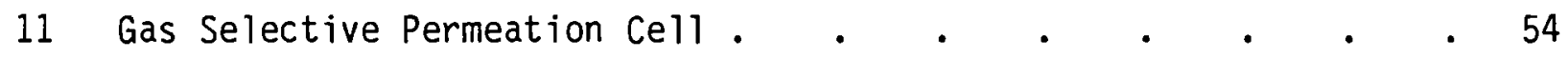

Permselective Membrane Apparatus for Gas Separation and
Measurement
. . . . . . . . . . 55 
3

. 


\section{TABLES}

1 Estimated Annual Production of Byproduct $\mathrm{CO}$. . . . . 6

2 Synthesis Gas Chemicals . . . . . . . . 8

3 Utility, Chemical and Capital Requirements for Commercial CO Separation Processes. . . . . . . . . 12

4 Estimated Carbon Balance for Blast Furnace \#3,

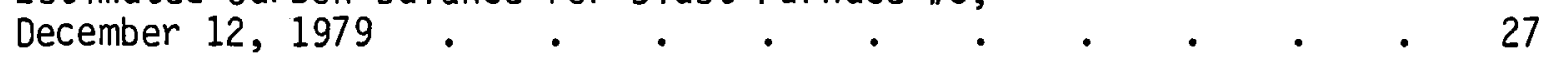

5 Estimated Carbon Balance for Blast Furnace \#4,

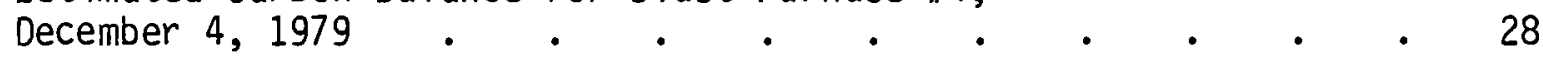

6 Average Quantities and Concentrations of Carbon Monoxide and Hydrogen in Basic, Oxygen-Process and Blast-Furnace Gas, Fontana, California . . . . . . . . . . 30

7 Energy Consumption for Ammonia Synthesis . . . . . 33

8 Energy Consumption for Methanol Synthesis . . . . . 35

9 Hydrogen Production from Coke-Oven Gas: Material Balance . $\quad 37$

10 Energy Consumption for Hydrogen Production . . . . . 39 
$\checkmark$ 


\section{INTRODUCTION}

Carbon monoxide $(\mathrm{CO})$ and hydrogen $\left(\mathrm{H}_{2}\right)$ are intermediates in the routes to several major industrial chemicals. Byproduct gases from several industries contain significant quantities of carbon monoxide and hydrogen. Currently chemical producers use natural gas to manufacture most of the intermediate carbon monoxide and hydrogen, and the industries producing the byproduct gases burn them as fuel or waste them. In a study funded by the U.S. Department of Energy, the Pacific Northwest Laboratory (PNL) investigated the potential for resource conservation by utilizing carbon monoxide and hydrogen from industrial byproduct gases in chemical production. The purpose of the study was to identify potentially viable projects and to facilitate their implementation.

In the first phase of the study PNL surveyed byproduct gas sources, potential chemical products, and the technology for recovery of carbon monoxide and hydrogen from dilute gas streams. This survey led to two tasks in the second phase of the study. In the major task the technical and economic feasibility of specific projects was analysed in two industries that produce byproduct gases. The analysis was based on the results of sampling programs, a market survey for potential products, material and energy balances, a preliminary design and cost estimation study, and numerous discussions with representatives of the chemical and other byproduct-gas-producing industries. In the other task, experiments were performed to develop a semipermeable membrane that would selectively separate carbon monoxide from mixtures with other gases. This report reviews the process of selecting specific cases for analysis, presents results of the analyses performed under the first task, and presents the results of the experiments performed under the second task. 
$-$ 


\section{CONCLUSIONS AND RECOMMENDATIONS}

The production of several commercial chemicals is technically feasible using byproduct gas from several industrial operations. In many cases pilotscale development would be required only for the gas-cleaning operation which would involve new applications of relatively standard gas-cleaning technology.

For the major chemical products and byproduct gas sources studied, the economic feasibility of large-scale chemical production is marginal, at best, under current conditions. The production of methanol from elemental phosphorus byproduct gas is constrained by the amount of gas available at any one plant. Sufficient ammonia or methanol could be produced with byproduct gas from a few of the larger steel mills in the United States to match conventional scales of production, but the high demand for gaseous fuels at steel mills makes it unlikely that such a venture would have clear economic feasibility.

Acetic acid, the isocyanates, formic acid or oxalic acid might be produced more economically than methanol or ammonia using carbon monoxide from elemental phosphorus byproduct gas. Carbon monoxide from steel mill gases would be somewhat more costly, but the availability of hydrogen as well as carbon monoxide makes isocyanate production particularly attractive. Case by case market analysis would be required to determine the economic feasibility of producing these chemicals.

A substantial amount of byproduct carbon monoxide is available in concentrations below $30 \%$, from which its recovery is not economically feasible with current technology. A simple and efficient technique such as selective membrane permeation might make such recovery economically attractive. Further research in this area is recommended.

Market and production conditions are likely to allow a viable chemical production venture at any of several byproduct gas sources either now or in the future. Identification of such a venture will require communication between the byproduct gas producers and chemical industry personnel who are familiar with markets and technology for the appropriate chemicals. 


\section{SELECTION OF CASES FOR STUDY}

This study focuses on the use of byproduct gases from only two types of industrial operations in the production of a few of several possible chemicals. This section reviews the alternatives and presents factors that must be considered in identifying a feasible chemical production venture.

\section{BYPRODUCT GAS SOURCES}

In the first phase of this study, PNL performed a comprehensive survey of sources for industrial byproduct gas containing carbon monoxide. The results of the survey have been published (Rohrmann et a1. 1977). Sources were identified in a variety of industries, and information was collected on the nature and availability of the byproduct gases to allow evaluation of the ir potential as chemical feedstocks.

The data collected in the byproduct gas survey are summarized in Table 1 (Rohrmann et a 1. 1977). Most of the data are based on the period from 1973 through 1975 except for those on the iron and stee 1 and coke-oven industries which have been adjusted to reflect U.S. production levels in 1979. Several industries produce 1 million tons per year or more of recoverable byproduct carbon monoxide. The concentration at which that carbon monoxide is available (last column) and the number of sites over which a given quantity is distributed (figures in parenthesis), however, are essential to its utility for chemical production. Those factors determine the need for a concentration step and the possible scale of operation; both of which are important to the capital cost of using the carbon monoxide.

It is apparent from the table that most of the gases containing carbon monoxide at concentrations in excess of $20 \%$ are currently used as fuel. Some of those not used as fuel are produced by batch processes, making them available over only a portion of a cycle ranging in length from several minutes to several hours. Since the demands of fuel or other uses are unlikely to match this cycle, the gases would have to be collected in expensive gas-holding equipment to provide a continuous supply. Those byproduct gases that are used 
TABLE 1. Estimated Annual Production of Byproduct Co(a)

\begin{tabular}{|c|c|c|c|c|c|}
\hline & \multicolumn{5}{|c|}{ Amount of $\mathrm{C} 0,1000$ tons $/ \mathrm{yr}$} \\
\hline & $\begin{array}{l}\text { Produced } \\
\text { Theoretically }\end{array}$ & $\begin{array}{l}\text { Recoverable } \\
\text { from } \\
\text { Process } \\
\end{array}$ & $\begin{array}{l}\text { Used at } \\
\text { Present }(b)\end{array}$ & $\begin{array}{l}\text { Flared or } \\
\text { Exhausted }\end{array}$ & $\begin{array}{l}\text { Co } \\
\text { Content, } \\
\text { vol\% } \\
\end{array}$ \\
\hline \multicolumn{6}{|l|}{ Iron and Stee } \\
\hline $\begin{array}{l}\text { Sinter } \\
\text { Blast } \\
\text { BOF without }\end{array}$ & $\begin{array}{l}1,125(41) \\
46,407(53)\end{array}$ & $\begin{array}{l}1,125(41) \\
46,407(53)\end{array}$ & $\begin{array}{l}0 \\
35,818 \quad(53)\end{array}$ & $\begin{array}{ll}1,125 & (41) \\
10,589 & (53)\end{array}$ & $\begin{array}{l}0.35 \\
22.5\end{array}$ \\
\hline $\begin{array}{l}\text { Suppressed } \\
\text { Combustion } \\
\text { BOF with }\end{array}$ & $5,100(32)$ & $10(32)$ & 0 & $10(32)$ & 0.3 \\
\hline $\begin{array}{l}\text { Suppressed } \\
\text { Combustion } \\
\text { Electric }\end{array}$ & $\begin{array}{l}720(5) \\
2,400(125)\end{array}$ & $\begin{array}{l}510(5) \\
25(125)\end{array}$ & $\begin{array}{l}0 \\
0\end{array}$ & $\begin{array}{l}510(5) \\
25(125)\end{array}$ & $\begin{array}{l}50 \\
0-6\end{array}$ \\
\hline $\begin{array}{l}\text { Ferroalloys } \\
\text { FeMn }\end{array}$ & $976(9)$ & & $543(1)$ & $74(1$ & 40 \\
\hline $\begin{array}{l}\mathrm{FeCr} \\
\mathrm{FeSi}\end{array}$ & $\begin{array}{l}413(10) \\
1,484(15)\end{array}$ & $\begin{array}{l}\text { (c) }(10) \\
300(3) \\
\text { (c) }(12)\end{array}$ & $\begin{array}{l}0 \\
78(1)\end{array}$ & $\begin{array}{l}\text { (c) }(10) \\
222(3) \\
\text { (c) }(12)\end{array}$ & 90 \\
\hline SiMn & $148(8)$ & $\begin{array}{l}44(1) \\
(c)(7)\end{array}$ & 0 & $\begin{array}{l}44(1) \\
(c)(7)\end{array}$ & 65 \\
\hline Other Alloys & $250(11)$ & (c) & 0 & (c) & \\
\hline \multirow{4}{*}{$\begin{array}{l}\text { Coke Ovens } \\
\text { Silicon Products } \\
\text { Aluminum } \\
\text { Phosphorus } \\
\text { Titanium Dioxide } \\
\text { Carbon Black } \\
\text { (furnace) } \\
\text { Calcium Carbide } \\
\text { Lead and Tin } \\
\text { Zinc (therma } 1 \text { ) } \\
\text { Petroleum } \\
\text { Refining } \\
\text { Kraft Paper }\end{array}$} & $\begin{array}{l}1,914(63) \\
370(10) \\
1,695(32) \\
1,316(9) \\
275(8)\end{array}$ & $\begin{array}{l}1,914 \quad(63) \\
(c) \\
244(5) \\
1,316(9) \\
275(8)\end{array}$ & $\begin{array}{l}1,1914 \quad(63) \\
0 \\
0 \\
1,184(9) \\
0\end{array}$ & $\begin{array}{ll}0 & \\
(c) & \\
244 & (5) \\
132 & (9) \\
275 & (8)\end{array}$ & $\begin{array}{l}6 \\
30 \\
98 \\
15\end{array}$ \\
\hline & $\begin{array}{l}2,275(29) \\
183(5) \\
363(7) \\
162(2)\end{array}$ & $\begin{array}{l}2,275(29) \\
165(3) \\
363(7) \\
162(2)\end{array}$ & $\begin{array}{l}33(1) \\
65(2) \\
0 \\
142 \quad(2)\end{array}$ & $\begin{array}{l}2,242(29) \\
100(3) \\
363(7) \\
20(1)\end{array}$ & $\begin{array}{l}6 \\
75 \\
<1 \\
80\end{array}$ \\
\hline & $14,561(149)$ & $14,561(149)$ & $10,921(112)$ & $3,640(37)$ & 8 \\
\hline & $160(116)$ & $160(116)$ & $\underline{0}$ & $160(116)$ & $<1$ \\
\hline TOTAL & 82,297 & 70,473 & 50,698 & 19,775 & \\
\hline \multicolumn{6}{|c|}{$\begin{array}{l}\text { (a) The numbers in parenthesis represent the number of sites in the United } \\
\text { States. } \\
\text { (b) Used entirely as fuel. }\end{array}$} \\
\hline
\end{tabular}


as fuel would have to be replaced with an alternate source of heat. In either case, the cost would have to be considered in evaluating the gases'utility as chemical feedstocks.

This study was initially directed at utilization of waste carbon monoxide; however, hydrogen is also present in several industrial byproduct gases and is required for producing several of the same chemicals that require carbon monoxide. Three types of byproduct gases (listed in Table 1) that contain hydrogen as well as carbon monoxide are coke-oven gas, carbon black off gas and several of the byproduct gases from petroleum refining. Possible uses of the byproduct hydrogen in coke-oven gas will be discussed in a later section.

\section{POTENTIAL PRODUCTS}

Carbon monoxide and hydrogen are intermediates in routes that are or have been used for commercial production of several industrial chemicals. In the United States, these routes generally start with natural gas as the feedstock for steam reforming to generate synthesis gas, a mixture composed primarily of carbon monoxide and hydrogen. If required, pure carbon monoxide can be produced by separation, or the mixture can be completely converted to hydrogen by the shift reaction followed by carbon dioxide removal. The remaining steps to the chemical products are virtually insensitive to the method of generation of the carbon monoxide, hydrogen or synthesis gas intermediates. Thus, carbon monoxide and/or hydrogen recovered from industrial byproduct gas can be used, without the need for new technology, in chemical production that would otherwise consume natural gas. Because the reforming step is eliminated, reductions in total energy consumption and capital cost may be additional benefits.

The major commercial chemicals produced by routes that use carbon monoxide and/or hydrogen are listed in Table 2. Production of most of these chemicals is discussed in an earlier report (Rohrmann et al. 1977). The current U.S. market for those chemicals is discussed in relation to byproduct gas utilization in Appendix A which summarizes a market survey performed by PNL in early 1980. 
TABLE 2. Synthesis Gas Chemicals

\begin{tabular}{|c|c|c|c|c|c|}
\hline \multirow{2}{*}{$\begin{array}{c}\text { Product } \\
\text { (Intermediate) }\end{array}$} & \multirow{2}{*}{$\begin{array}{l}1979 \text { U.S. } \\
\text { Production, } \\
1000 \text { ton } / y r\end{array}$} & \multirow{2}{*}{$\begin{array}{c}\text { Potential } \\
\text { C0 Demand (a), } \\
1000 \text { ton } / y r \\
\end{array}$} & \multicolumn{3}{|c|}{$\begin{array}{r}\text { Unit Consumptions, } \\
1000 \mathrm{Btu}(\mathrm{LHV}) / \mathrm{lb}(\mathrm{b})\end{array}$} \\
\hline & & & $\mathrm{CO}$ & $\mathrm{H}_{2}$ & Fue 1 \\
\hline Ammonia & 17,500 & 69,000 & 0 & 9.2 & 6.3 \\
\hline Methanol & 3,700 & 14,200 & 3.3 & 7.6 & 4.4 \\
\hline Acetic acid $(c)$ & 1,650 & 835 & 2.2 & 0 & -- \\
\hline $\begin{array}{l}\text { Acrylic acid and } \\
\text { esters }(c)\end{array}$ & 470 & 151 & $1.0-1.7$ & 0 & -- \\
\hline $\begin{array}{l}\text { n-Butanol } \\
\text { (Butyradehyde) }\end{array}$ & 365 & 504 & $\begin{array}{l}0 \\
2.0\end{array}$ & $\begin{array}{l}1.7 \\
1.7\end{array}$ & -- \\
\hline Toluene & & & & & \\
\hline $\begin{array}{l}\text { di-isocyanate } \\
\text { (Phosgene) } \\
\text { (Toluene di-amine) }\end{array}$ & 340 & 734 & $\begin{array}{l}4.2 \\
0\end{array}$ & $\begin{array}{l}0 \\
4.4\end{array}$ & -- \\
\hline Methylene di-phenyl & & & & & \\
\hline $\begin{array}{l}\text { isocyanate } \\
\text { (phosgene) }\end{array}$ & 238 & 55 & 1.0 & 0 & -- \\
\hline $\begin{array}{l}\text { 2-Ethyl hexanol } \\
\text { (Butyraldhyde) }\end{array}$ & 160 & 246 & $\begin{array}{l}0 \\
2.2\end{array}$ & $\begin{array}{l}1.7 \\
1.7\end{array}$ & -- \\
\hline Propionic acid & 46 & 47 & 2.2 & 1.9 & -- \\
\hline Formic acid $(c)$ & 34 & 23 & 2.9 & 0 & -- \\
\hline $\begin{array}{l}\text { Oxalic acid } \\
\text { (Sodium formate) }\end{array}$ & 9 & 6 & $\begin{array}{l}0 \\
3.0\end{array}$ & $\begin{array}{l}(1.1)^{(d)} \\
0\end{array}$ & \\
\hline
\end{tabular}

\footnotetext{
(a) Assuming all production and unit consumptions are derived from CO.

(b) Consumptions per pound of final product. LHV = lower heating value.

(c) All or part of current production is based on non-synthesis gas route.

(d) Hydrogen byproduct.
}

The 1979 production volume and potential carbon monxide demand in the United States is listed for each chemical in the first two columns of Table 2. The total potential carbon monoxide demand for all chemicals listed is 86 million tons per year. Comparison of the figure with the total potentially recoverable byproduct carbon monoxide from all sources listed in Table 1 of 
70 million tons per year indicates that byproduct gas utilization could have a significant impact on an important end use of natural gas. Since each ton of carbon monoxide utilized for chemical production could displace approximately its fuel value equivalent $(8.7$ million Btu) of natural gas, a total displacement on the order of 0.6 quadrillion Btu of natural gas feedstock is theoretically possible. On a more practical level, specific byproduct sources must be matched with specific chemical manufacturing ventures. The relationship of the size and location of the byproduct gas source to the size and distribution of the market for the potential chemical product(s) is important as well as the characteristics of the source listed in the previous section.

Table 2 lists the energy content of the carbon monoxide and hydrogen required to produce one pound of each chemical product. Additional energy would be required to drive the natural gas reforming reaction, to adjust the carbon monoxide to hydrogen ratio of the synthesis gas, and to operate other processing equipment. This additional energy is shown in the last column for methanol and ammonia; similar data for the remaining chemicals are not readily available. The sum of the three columns under the heading Unit Consumptions, especially the sum of carbon monoxide and hydrogen, indicates the potential impact that utilization of byproduct carbon monoxide or hydrogen could have on the operating cost of a chemical plant. The greater the sums, the greater the potential reductions in operating costs. The capital cost could also be less than a conventional plant for the same product because a byproduct gas source supplies the entire carbon monoxide and hydrogen requirement, and the reforming step can be eliminated. In addition, a gas separation step is required when carbon monoxide alone is used in producing a chemical or one of its intermediates. The capital and operating cost of that step could be eliminated by using a byproduct source of relatively pure carbon monoxide.

Two potential chemical products not listed in Table 2 are carbon monoxide and hydrogen for use at a remote location. Although Appendix A identifies substantial market potential for the synthesis gas chemicals, transportation costs and production-scale factors may preclude location of a chemical plant at the site where byproduct gas is available. Remote use of carbon monoxide or hydrogen could allow location of a chemical plant at a site that would minimize 
transportation costs for the product(s) and other raw materials or could allow supplementation of a conventional source of synthesis gas at a larger, more economical, chemical plant. In the case of hydrogen, markets other than the synthesis gas chemicals could also be served.

Compared with methane, carbon monoxide has three times the volume and five times the weight per unit energy content. As a result it is more expensive to transport and cannot be economically piped over long distances as can natural gas. On the other hand, for certain chemical products carbon monoxide is a substantially more valuable feedstock than natural gas. Carbon monoxide is delivered by pipeline to several chemical producers on the Gulf Coast by Air Products and Chemicals, Inc. of Houston, Texas. According to C.J. Forest of Air Products and Chemicals, Inc. (personal communication, February 1980), delivered carbon monoxide can command a price per unit fuel value ten times the unit price of the fuel used to produce it. For example, if natural gas is available at $\$ 2 / 10^{6} \mathrm{Btu}$, carbon monoxide might be delivered to a chemical producer for $\$ 20 / 10^{6}$ Btu or about $9 \$ / 1 b$. Short-range pipeline delivery is, therefore, feasible where local market conditions permit. According to Brian Rogers of Air Products and Chemicals, Inc. (personal communication, January 1981) pipeline delivery distances of up to $25 \mathrm{mi}$ might be feasible under prevailing economic conditions.

Carbon monoxide could potentially be shipped over much greater distances as a liquid. Liquid carbon monoxide, however, is flammable, is difficult to detect (like liquified natural gas), dissipates more slowly in air, and is highly toxic. Extreme safety precautions are, therefore, essential for its bulk transport.

There is no regulation applicable to transport of carbon monoxide as a liquid. According to Paul Seay, Chief of the Engineering Branch of the Office of Hazardous Materials Regulation, Materials Transportation Bureau, U.S. Department of Transportation (personal communication 1981), Liquid Carbonic and Dow Chemical have exemptions to ship liquid carbon monoxide by tank truck. Jack Trautwe in of Liquid Carbonic (personal conmunication 1981) stated that Liquid Carbonic is the only commercial supplier of liquid carbon monoxide. Their customers maintain tanks of carbon monoxide in liquid form as a back-up 
for a conventional source of the gas. The large amount of equipment required and the extensive maintenance and safety procedures would probably make liquid carbon monoxide transportation as a steady supply for chemical production prohibitively expensive.

Hydrogen is intermediate in cost of transportation between carbon monoxide and natural gas. Like carbon monoxide, hydrogen is also more valuable as a chemical feedstock than as a fuel. In mid-1980, the minimum price for pipeline delivery was equivalent to $\$ 11 / 10^{6}$ Btu of hydrogen (Fallwell and Greek 1980). Separation and marketing of hydrogen will be discussed in a separate section.

\section{BASIS FOR SELECTION}

PNL directed its study of the technical and economic feasibility of chemical production with industrial byproduct gas toward specific cases considered most likely to yield a feasible venture. These cases were selected by giving primary consideration to concentration and size of available byproduct gas streams and to unit consumption (see Table 2) and production volume of potential chemical products. Consideration of these and the other factors identified earlier in this section indicates that several other cases may be feasible although less generally applicable than those selected.

A gas stream containing $10 \%$ or more of a component other than carbon monoxide or hydrogen must generally be enriched in some way before it can be used in the production of any of the synthesis gas chemicals. Carbon dioxide $\left(\mathrm{CO}_{2}\right)$ can be removed by several well-established absorption processes, and the cost is generally not prohibitive (Mullowney 1957; Erickmeyer 1958; Buck and Leitch 1958). Hydrogen can be separated easily from most gases because of its low molecular weight; its separation will be discussed in the iron and steel section of this report. Carbon monoxide and nitrogen have the same molecular weight, however, and neither is polar, like carbon dioxide, which makes them more difficult to separate by absorption. Nitrogen is frequently present at concentrations greater than $10 \%$ in byproduct gas streams containing carbon monoxide. 
The cost of separating carbon monoxide from mixtures with nitrogen is high and sensitive to carbon concentration. Three different technologies are compared in Table 3 for separation of carbon monoxide from a gaseous mixture. The table is based on an article by the developers of the COSORB ${ }^{\circledR}$ process (Haase and Walker 1974), and the feed gas used for comparison was chosen to favor the cryogenic process. If the feed contained large amounts of nitrogen, the COSORB ${ }^{\circledR}$ and copper liquor processes would not be greatly affected, while

TABLE 3. Utility, Chemical and Capital Requjrements for Commercial Co Separation Processes (a)

\begin{tabular}{|c|c|c|c|}
\hline \multirow[b]{2}{*}{ Type of Requirement } & \multicolumn{3}{|c|}{ Amount Required per Pound of $\mathrm{CO}$} \\
\hline & COSORB ${ }^{\circledR}$ & $\begin{array}{l}\text { Copper } \\
\text { Liquor } \\
\end{array}$ & Cryogenic \\
\hline $\begin{array}{l}\text { Utility } \\
\text { Power, Btu (electric) }\end{array}$ & 300 & 228 & 639 \\
\hline $\begin{array}{l}\text { Steam, Btu (thermal) } \\
050 \text { psig } \\
0600 \text { psig }\end{array}$ & $\begin{array}{r}1418 \\
262\end{array}$ & $\begin{array}{c}3710 \\
--\end{array}$ & $\begin{array}{l}-- \\
-\end{array}$ \\
\hline $\begin{array}{l}\text { Water, lb } \\
\text { Cooling } \\
\text { Process }\end{array}$ & $\begin{array}{c}45 \\
--\end{array}$ & $\begin{array}{l}153 \\
3\end{array}$ & 17 \\
\hline $\begin{array}{l}\text { Chemicals, lb } \\
\text { Toluene } \\
\text { Ammonia } \\
\text { Lean MEA Solution } \\
\text { Nitrogen }\end{array}$ & $\begin{array}{l}8.4 \times 10^{-5} \\
-- \\
-- \\
--\end{array}$ & $\begin{array}{l}--\overline{5} \times 10^{-3} \\
2.0 \\
--\end{array}$ & $\begin{array}{l}-- \\
\overline{--} \\
1 . \overline{2} \times 10^{-3}\end{array}$ \\
\hline $\begin{array}{l}\text { Capital Investment for } \\
100 \text { million } 1 \mathrm{~b} / \mathrm{yr} \\
\text { c0 Production: }\end{array}$ & & & \\
\hline $\begin{array}{l}\text { Millions of } \\
1980 \text { do } 11 \text { ars }\end{array}$ & 4.1 & 6.0 & 6.9 \\
\hline
\end{tabular}

(a) $\mathrm{CO}$ is delivered at 90 psig from a mixture containing $25 \% \mathrm{CO}$, $71 \% \mathrm{H}_{2}, 4 \% \mathrm{CH}_{4}, 0.1 \% \mathrm{~N}_{2}$, and $50 \mathrm{ppm} \mathrm{CO}$. Capital investment is for inside battery limits equipment only.

(8) COSORB is a registered trademark of Tenneco Chemicals, Inc. 
utility and capital requirements for the cryogenic process would increase substantially. The table is based on a feed gas that does not need to be compressed. Most byproduct gases, however, are available at atmospheric pressure. Feed gas compression adds a substantial energy requirement to carbon monoxide separation from a byproduct gas that increases sharply with decreasing concentration as illustrated by Figure 1. Capital cost of the compressor would be a major factor for a 25\% carbon monoxide feed gas and would become predominant at lower carbon monoxide concentrations.

Utilization of byproduct carbon monoxide available in concentrations below $30 \%$ was considered unlikely to be feasible with current technology. Improved separation technology could potentially make feasible the utilization of the

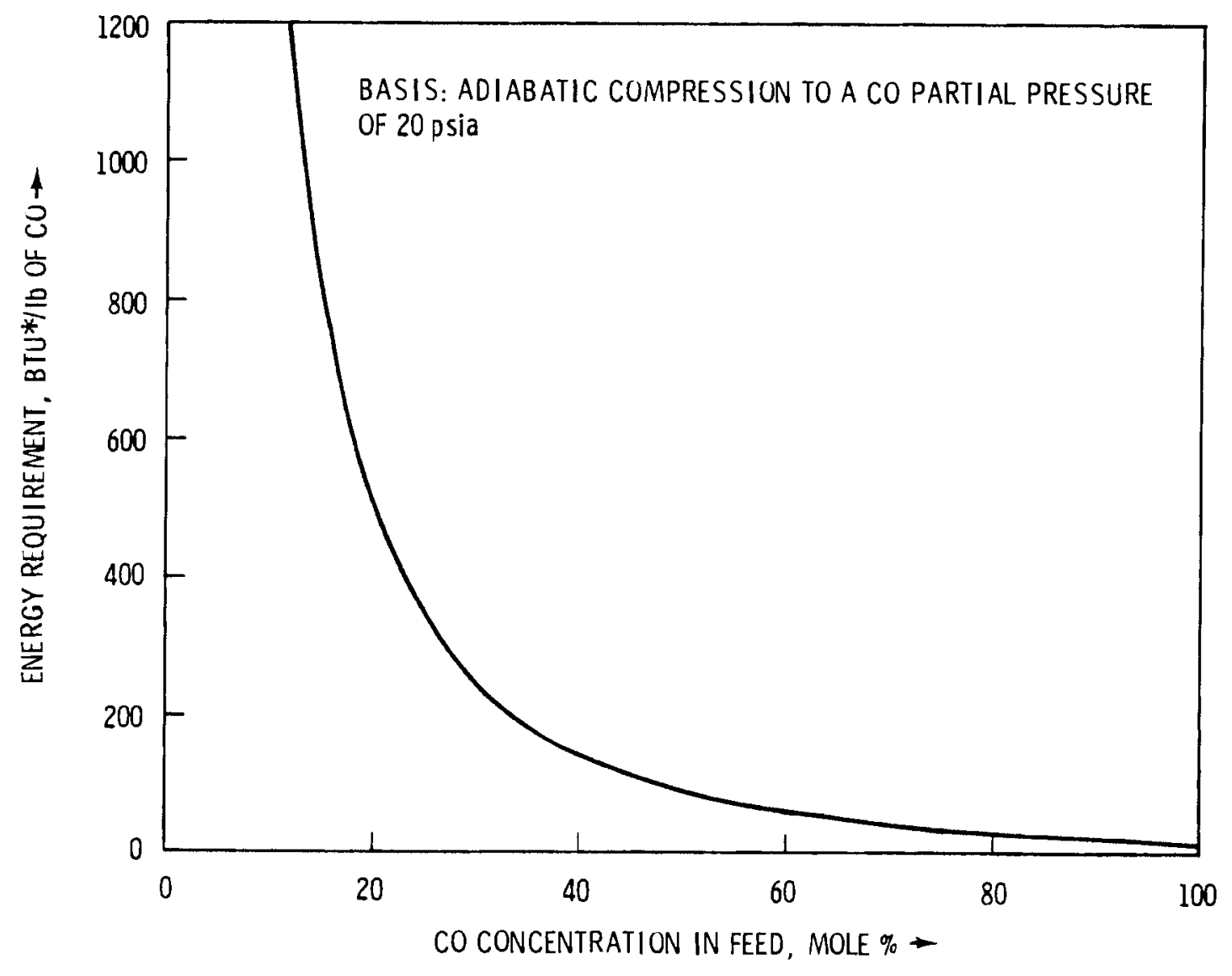

* WORK, NOT THERMAL REQUIREMENT

FIGURE 1. Compression Energy for Feed Gas to CO Separation 
large quanitity of byproduct carbon monoxide available in that concentration range (see Table 1). The energy required by current technology is well above the minimum thermodynamic requirement for separation of carbon monoxide from a gaseous mixture and is also more sensitive to carbon monoxide concentration, leaving room for significant improvement. This is illustrated by Figure 2, which can be compared with the utility requirements in Table 3 and with Figure 1. The large potential benefits from realization of even a portion of the possible improvement provided the impetus for the second task of this study.

In addition to concentration, size, or the quantity of carbon monoxide potentially available per site, another factor was given primary consideration in selecting specific types of byproduct gas sources for study. Cleaning and compressing the byproduct gas as well as producing a chemical product would

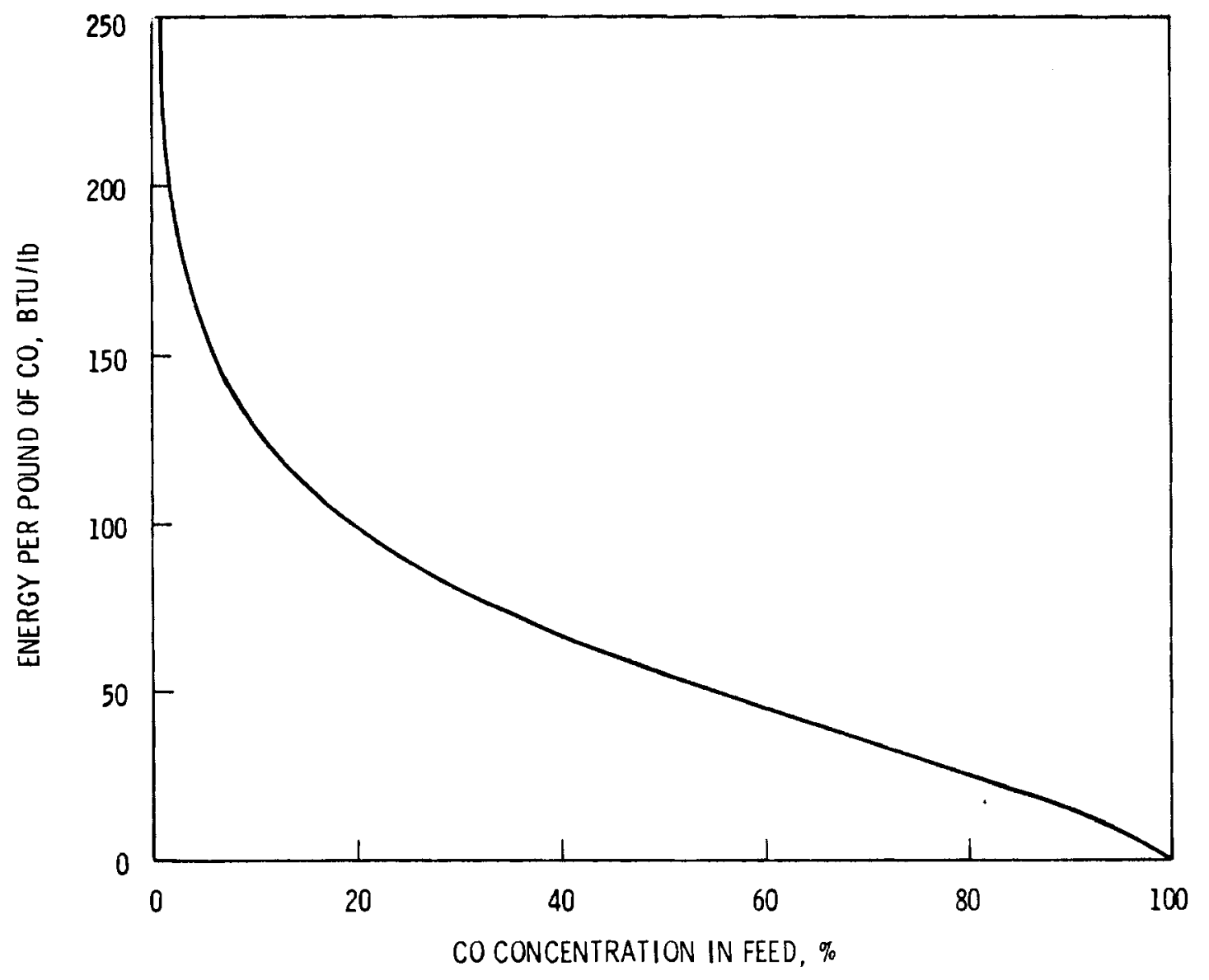

FIGURE 2. Minimum Energy Required to Separate CO from a Mixture of Gases at Constant Temperature and Pressure 
tend to be more economical for larger sources. Review of Table 1 shows that only the iron and steel, ferroalloys and phosphorus industries contain operations that produce carbon monoxide at concentrations greater than $30 \%$ and in average quantities per site greater than 100,000 tons per year. The iron and stee 1 industry was selected because of its size and, hence, potential impact on the chemical industry; the phosphorus industry was selected because of the unusually high concentration of the byproduct carbon monoxide from elemental phosphorus furnaces.

All of the chemicals in Table 2 were considered for production with iron and steel or phosphorus industry byproduct gases; however, ammonia and methanol received primary consideration. These two chemicals can be produced with byproduct gas as the only feedstock, and they represent the largest potential application of byproduct gas in the chemical industry.

Four of the chemicals listed in Table 2 require carbon monoxide only and not a $\mathrm{CO} / \mathrm{H}_{2}$ synthesis gas. Acetic acid and phosgene, a precursor to the isocyanates, are intermediate in size compared with methanol and ammonia, and the ir production requires additional chemicals to react with the carbon monoxide. Formic acid and oxalic acid are small-volume chemicals.with limited market potential. Any of the four would require careful analysis of markets in the vicinity, but, because of the high cost of generating pure carbon monoxide from natural gas, use of byproduct carbon monoxide should be considered wherever a byproduct gas source is available containing carbon monoxide at concentrations greater than $30 \%$. 
a 


\section{THE ELEMENTAL PHOSPHORUS INDUSTRY}

Utilization of the carbon monoxide-rich byproduct gas from the production of elemental phosphorus was a major focus of this study. The Monsanto Company, a major producer of elemental phosphorus, cooperated with PNL in this study by providing technical assitance and access to their facilities. PNL contracted with Battelle-Columbus Laboratories to perform sampling and analysis at Monsanto's Soda Springs, Idaho plant. PNL subsequently contracted with The Lummus Company to perform a feasibility-engineering study of methanol production using the Soda Springs byproduct carbon monoxide. This section reviews the byproduct gas characterization and methanol feasibility studies, which have resulted in a published report. Other chemicals that may be produced and the outlook for carbon monoxide utilization in the phosphorus industry are also discussed.

\section{SAMPLING PROGRAM}

Battelle-Columbus Laboratories performed sampling at Monsanto's Soda Springs, Idaho elemental phophorus plant between July 24 and 31,1978 . The results of their sampling program are summarized in Appendix B. The summary was prepared by PNL as a basis for the methanol feasibility study that followed. The results confirm the potential utility of the gas streams sampled and, although some of the data on impurities is inconclusive, allows estimation of the required type and extent of gas cleaning.

The byproduct gas is an extremely rich source of carbon monoxide, containing $95 \%$ to $98 \%$ by volume on a dry basis, with nitrogen as the major impurity and small amounts of oxygen and hydrogen present. The gas may be saturated with phosphorus vapor which could amount to $\sim 3 \mathrm{lb}$ or more of phosphorus per ton of carbon monoxide. Removal of the phosphorus would be required before chemical synthesis and its value would probably be sufficient to justify recovery and return to the phosphorus plant.

Levels of sulfur compounds, halogens and hydrogen cyanide are listed and are all high enough to require removal before contact with most catalysts for 
synthesis of chemicals such as methanol. Loading and composition of particulates and volatile compounds are given. Removal of particulates would be required before compression. The extremely high level of measured volatile compounds may be the result of attack on the glass and stainless steel components of the sampling train by the chlorides and fluorides in the off gas. The report concludes that due to uncertainty, further sampling should be performed if any of the particulate or volatile components represent a significant cleanup requirement. The clean-up system designed for the methanol plant described in the next section, however, removes the volatile and particulate components in alkaline scrubbing towers that would be required in any case to remove the trace, acid gases.

METHANOL STUDY

PNL performed a detailed analysis of the technical and economic feasibility of methanol production using the byproduct carbon monoxide from Monsanto's Soda Springs, Idaho elemental phosphorus plant. The Lummus Company performed screening of options and subsequent flowsheet development and cost estimation for PNL. The results of this analysis were generalized for the elemental phosphorus industry and published (Lyke and Moore 1980).

The methanol production option found most attractive in the analysis was a scheme that would use $1.33 \times 10^{9} \mathrm{Btu} / \mathrm{h}$ of natural gas along with $0.24 \times 10^{9}$ $\mathrm{Btu} / \mathrm{h}$ of off gas to take advantage of the economics of scale in methanol production. Methanol could be produced more economically than by a conventional, natural-gas-based plant at the same site, but the advantage would be insufficient to overcome current market uncertainties and shipping costs for the Southeast Idaho location.

Production of methanol from carbon monoxide alone by converting two-thirds of the available carbon monoxide to hydrogen by the shift reaction was not economical for a 100,000-ton/yr elemental phosphorus plant. A rough estimate showed that a plant using carbon monoxide equivalent to a 200,000- to 250,000ton/yr phosphorus production rate might compete with methanol production from $\$ 4.50 /$ million Btu natural gas. Southeast Idaho and Central Tennessee each have 
a total elemental phosphorus capacity in that range. The logistics of a combined effort, however, would be formidable.

\section{OTHER CHEMICALS}

Because of its unusually high carbon monoxide content, elemental phosphorus byproduct gas is attractive for possible application to the production of acetic acid, the isocyanates, formic acid and oxalic acid, all of which require carbon monoxide only and not a synthesis gas. The methanol study (Lyke and Moore 1980) concluded that a clean and compressed stream of $97 \%$ carbon monoxide could be produced for $3 \phi / 1 b$ if off gas could be replaced in its current use for $\$ 2.50 / \mathrm{milli}$ ion Btu. This price shows significant potential compared with the figure of $9 \$ / 1 b$ for carbon monoxide from conventional sources cited earlier under "Potential Products."

A new acetic acid plant could consume about 150,000 tons/yr of carbon monoxide and would also require methanol as a feedstock. A toluene di-isocyanate plant could consume 50,000 tons/yr of carbon monoxide and would require toluene diamine and chlorine in addition. Methylene di-phenyl isocyanate would require aniline and chlorine and about 20,000 tons/h of carbon monoxide for a new plant. Further information on these chemicals is found in Appendix A.

Oxalic acid and formic acid (if produced from carbon monoxide) would both be made from sodium formate. About 5,000 to 10,000 tons/yr of carbon monoxide would be reacted with sodium hydroxide and then acidified. If sodium is recycled, lime and hydrochloric acid could be the other required feeds.

The chemicals discussed under this heading represent uses for from 5,000 to 150,000 tons/yr of carbon monoxide at a single site of commercial scale. Elemental phosphorus plants in the United States produce byproduct gas streams containing from 15,000 to 250,000 tons/yr of carbon monoxide. In addition to size, availability of other feeds, distance to potential markets, and importance of carbon monoxide cost in the overall processing cost would be important considerations in identifying a viable chemical production venture. 
OUTLOOK

The initiative for action as a result of this study would be most easily taken by the phosphorus producers. This is appropriate considering that they stand to gain the most from finding a higher value use for the ir byproduct-gas resources.

The first step toward identifying a feasible venture at a particular site would be to determine the least expensive way to replace the byproduct gas in its current use. Many fuel uses are amenable to replacement with coal. Next, contact with companies in the business of producing or licensing technology for potential chemical products might be in order. Market factors and the importance of carbon monoxide cost would be discussed. Using some of the cost data from this study, the advantage of using the byproduct gas could then be estimated as a function of the chemical production capacity to be installed. The market for that amount of the chemical product, the cost advantage and the availability of other required feedstocks would determine the economic feasibility of the venture. 
THE IRON AND STEEL INDUSTRY

The iron and steel industry is one of the largest single consumers of energy in the United States, and it is the largest single producer of byproduct gas. In 1979 the U.S. iron and steel industry(a) consumed 0.8 Quads ${ }^{(b)}$ of natural gas, 0.2 Quads of fuel oil, and 1.7 Quads of coal (American Iron and Stee 1 Institute 1980). The total energy content for all types of recoverable byproduct gas (see Table 1) produced by the iron and steel industry for 1979 was about 0.85 Quads. A large fraction of that total, $87 \%$, was utilized almost entirely as fuel in the production of raw steel.

This information is significant for this study because 1) the unused fraction of the byproduct gas represents a considerable amount of energy, and 2 ) the total amount of byproduct gas could potentially displace large quantities of valuable feedstocks if the byproduct gas were used for chemical production.

In comparing the iron and steel industry to the ammonia and methanol industries, the total energy content of the byproduct gas produced by the iron and stee 1 industry was 25\% more than the total energy consumption of the ammonia and methanol industries combined. The iron and steel industry consumed about four times as much energy as the combined ammonia and methanol industries. This large consumption and byproduct gas production are the result of the size of the industry. The tonnage of iron and steel produced in the United States in 1979 was about six times the tonnage of ammonia and methanol produced during the same period.

Kaiser Stee 1 Corporation cooperated in this study by providing access to their facilities and substantial information on their byproduct gas production and general operations. PNL contracted with TRW, Inc. to perform sampling and analysis at Kaiser's Fontana California steel plant. Opportunities for byproduct gas utilization at the site were investigated by PNL but no detailed

\footnotetext{
(a) In this section, the iron and stee 1 industry is taken to include all coke-oven operations as well.

(b) One Quad $=1015$ Btu.
} 
engineering sudy was performed as was done for the Soda Springs elemental phosphorus plant. Contacts were made with several other firms in the iron and stee 1 industry to gather information on byproduct gas production, current disposition, and utilization opportunities.

This section does not review project activities in chronological order. It summarizes current practice in the industry; presents results of the sampling program; discusses the production of ammonia, methanol, hydrogen and other chemical products from steel mill gases; explores two approaches to indirect use of carbon monoxide-rich gases; and reviews prospects for chemical production with steel industry byproduct gas.

\section{CURRENT INDUSTRIAL PRACTICE}

Stee 1 is produced by 1 ) the thermochemical reduction of iron ore (oxides of iron) to pig iron by carbon monoxide and hydrogen, usually from coke and supplementary fuels, in a blast furnace, followed by 2) removal of excess carbon by oxidation to carbon monoxide, removal of impurities by reaction with slag, and addition of scrap and alloying materials in a furnace such as an electric arc or basic oxygen furnace, and 3) various heat treating and forming steps depending upon the specific products desired. The production of coke and the first two major steel-making steps produce significant quantities of byproduct gas, while the heat treating and forming steps generally use byproduct gas as a major source of fuel. This study deals mostly with current U.S. steel-making technology. Integration of chemical production with newer technologies such as formcoke and direct reduction methods is beyond the scope of this study but no doubt will be considered before large-scale application in the United States.

Metallurgical coke is produced by pyrolysis of coal in batch-operated ovens heated by a portion of the pyrolysis gas, blast furnace gas, or other gaseous fuels. The pyrolysis gas is commonly processed to recover ammonia, sulfur and the "coal chemicals" that may include phenols, cresols, benzene, toluene, napthalene, creosote, tar and pitch (McGannon 1971). Coke-oven gas will be used here to refer to the gas that remains, composed primarily of hydrogen (typically 55\%), methane (28\%), carbon monoxide (6\%), nitrogen (4\%) and higher hydrocarbons $(4 \%)$. 
Most coke-oven gas is used as a fuel in steel making. In two sites where fuel applications do not exist or are less than the amount of gas available, however, United States Steel Corporation is producing ammonia from coke-oven gas. In Clairton, Pennsylvania, 1100 tons per day of anhydrous ammonia are produced, and in Geneva, Utah, 200 tons per day are produced and further processed to nitric acid and ammonium nitrate ( $H$. W. Paxton of United States Steel Corp., personal communication 1980).

Coke is charged to the top of blast furnaces along with iron ore and flux. The coke serves the dual function of physically supporting the iron as it is reduced and providing most of the reducing gas by its partial oxidation which also provides heat for melting. The injection of supplemental fuels (usually natural gas or 0il) along with the blast air near the base of the furnace provides part of the reducing gas and conserves coke. The gas leaving the top of the furnace contains nitrogen, reaction products water and carbon dioxide, and, due to equilibrium and kinetic limitations, unreacted carbon monoxide and some hydrogen. Typical composition as cited by McGannon (1971) was, on a dry basis, $27.5 \% \mathrm{CO}, 1 \% \mathrm{H}_{2}, 60 \% \mathrm{~N}_{2}$ and $11.5 \% \mathrm{CO}_{2}$. However, improved practices are reducing the amount of unreacted carbon monoxide (Brandi, Heynert and Wilms 1970). Some of the blast furnace gas is burned to heat stoves for preheating the blast air. Most of the remainder is used as fuel in the steel plant either alone or in combination with coke-oven gas or natural gas. Based on estimation from American Iron and Steel Institute (1980) data, about $20 \%$ of the blast furnace gas produced in the United States in 1979 was flared. Some gas waste is inevitable as upsets in supply or demand force temporary flaring at the furnace; however, a higher rate of utilization would seem to be possible.

Raw steel is produced from pig iron and scrap by one of three predominant processes in the United States. The basic oxygen process accounted for $61 \%$ of the steel produced in 1979, the electric arc 25\%, and the open hearth process 14\% (American Iron and Steel Institute 1980). Only the basic oxygen process has the potential for carbon monoxide recovery as practiced in the United States (Rohrmann 1977). No new open hearth furnaces are being constructed. Recently, the electric furnace has gained somewhat in production share relative to both the basic oxygen furnace and the open hearth. 
In the basic oxygen process (BOP), steel scrap, alloying and fluxing agents, and molten pig iron are charged to a refractory-lined, tiltable, opentop vessel; oxygen is blown through the bath of molten metal; and the liquid steel product is poured into a waiting ladle. The oxygen reacts with dissolved carbon in the bath, forming carbon monoxide and releasing sufficient heat to melt the scrap (McGannon 1971). Most furnaces introduce oxygen as a jet at the surface of the bath using a lance that is lowered into the vessel. In another type of construction, termed Q-BOP, oxygen is introduced from below. Several methods are used to handle the off gas. In most installations the gas burns at the top of the vessel and carbon monoxide recovery is not possible. The recent trend in construction, however, has been toward furnaces with tight-fitting hoods that are lowered during the oxygen blow and can collect the gas with a fairly small infiltration of air. These are called suppressed combustion furnaces. The oxygen lance, if present, fits through a hole in the hood.

Off gas is recoverable for 15 min or less during the oxygen blow of each heat. Depending upon the specific installation, 35 to 60 heats per day may be produced. If a steady supply of off gas is to be obtained it must be accumulated in gas-holding equipment. Average carbon monoxide concentrations of $60 \%$ to $75 \%$ are obtainable, with carbon dioxide and nitrogen making up the remainder of the gas (M. I. Tarkoff of Inland Steel, and H. W. Paxton of United States Stee 1, personal communications 1980).

Steel producers have installed suppressed combustion off-gas systems primarily as least-cost pollution control systems rather than for recovery of the gas. In all U.S. installations, the gas is flared, although BOP off gas is recovered as fuel at several locations in Europe and Jicpan (Curtis 1976). Figure 3 illustrates a BOP off-gas recovery system. A suppressed combustion system used for pollution control only would simply exhaust to the flare stack. An economic analysis for two different fuel applications of BOP gas was performed by Armco Steel Corporation in 1976 (Curtis 1976; American Iron and Steel Institute 1976) based on crediting recovered gas at $\$ 2 /$ million Btu. After tax, discounted cash flow, rates of return on investment of $9.1 \%$ and $15.0 \%$ were determined. The prevailing opinion in the steel industry is that construction costs have increased as fast as fuel costs, so that economics for off-gas 


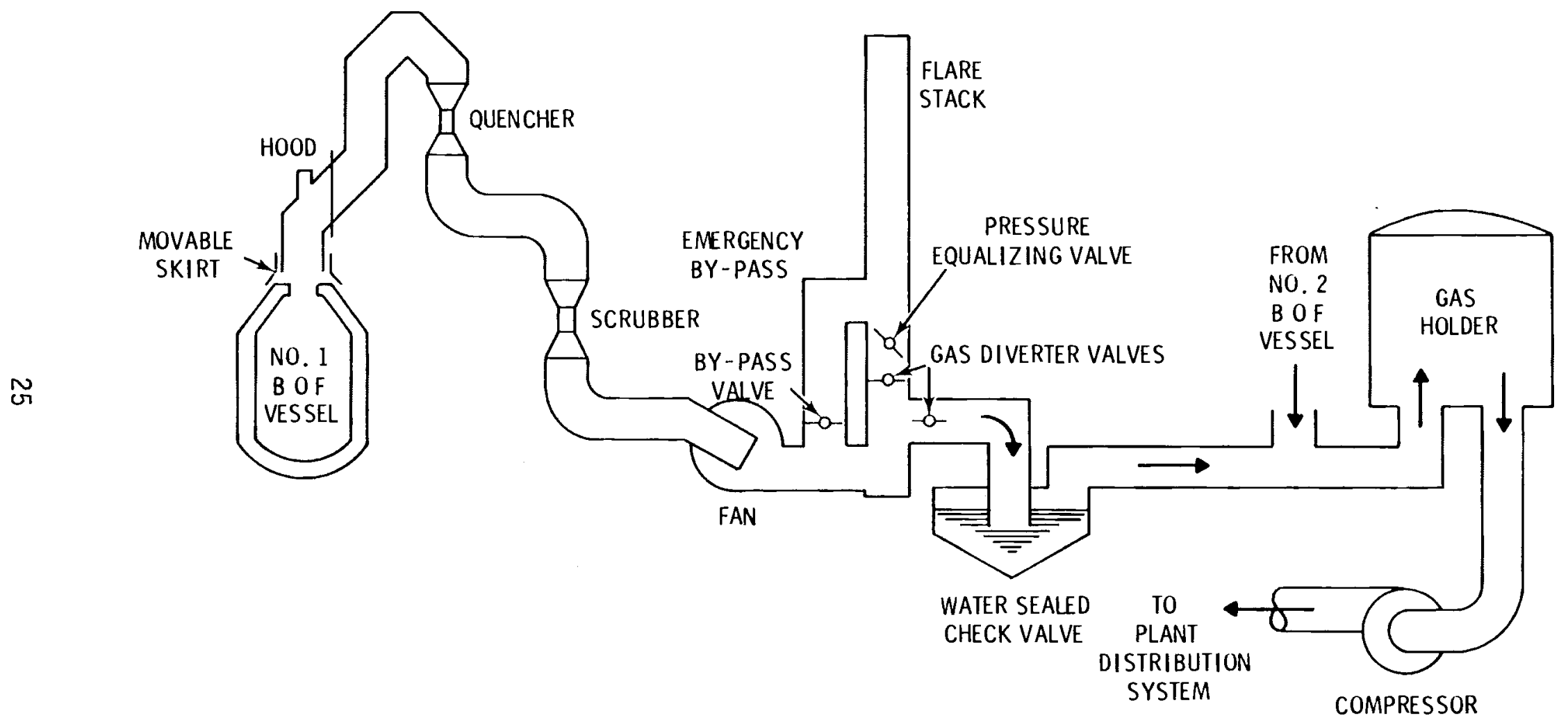

FIGURE 3. Basic 0xygen Process Off-Gas Recovery System 
collection remain marginal. This study, however, seeks to identify applications of carbon monoxide in chemical production that provide a higher value use and, hence, improved economics.

\section{SAMPLING PROGRAM}

PNL contracted with the Environmental Engineering Division of TRW, Inc., to perform sampling at Kaiser Steel's plant in Fontana, California. The purpose of the sampling program was to determine quantities and concentrations of carbon monoxide available in steel mill byproduct gases under actual operating conditions and to determine the levels of particulates and trace gases present that would require removal before chemical processing. Measurements were taken of off gas from each of the two furnaces in Kaiser's suppressed-combustion, basic, oxygen process shop and of off gas from two of Kaiser's four blast furnaces. Appendix $C$ is TRW's report.

The significance of the particulate and trace gas data collected by TRW (Appendix $C$ ) can be assessed by comparison with the elemental phosphorus offgas data (Appendix B). Particulate loading is higher for the blast furance and BOP gas, but it appears from the blast furnace gas particle sizing that about the same amount of very small particulates (less than $0.5 \mu \mathrm{m}$ ) may be present. Unlike the phosphorus off gas, none of the steel off gas contained halogen gases. TRW's data on sulfur compounds are sparse but show levels generally lower than for the phosphorus off gas. In general, particulate removal and desulfurization would probably be required before compression and contact with, for example, a methanol catalyst. It may be, however, that only particulate removal and drying would be required before feeding to the COSORB ${ }^{\circledR}$ process. Further testing would be required before proceeding with design of a pilot plant.

The quantity of available byproduct gas could not be accurately determined by direct measurement because of the difficulty in accurately determining average velocity profiles in large diameter stacks with variable flow rates. Concentrations were determined to usable accuracy. Kaiser Steel personnel provided operating data from which byproduct gas quantities could be determined by material balance. 
Tables 4 and 5 summarize data collected for one day of operation at each blast furnace tested. The carbon input and output is based on information supplied by Kaiser, while the gas composition is from TRW's report.

Figure 4 is a typical concentration profile from TRW's report based on ten integral samples taken during a heat at Kaiser's basic oxygen process shop. For ease of operation and to insure no leakage of $C O$ into the shop area, the fume hoods are not lowered to their tightest position over the vessels and excess air is drawn through the system. The resulting dilution of the off gas is tolerable because it is not being collected for use. Figure 5 is based on

TABLE 4. Estimated Carbon Balance for Blast Furnace \#3, December 12, 1979

\begin{tabular}{|c|c|}
\hline & $\begin{array}{c}\text { Carbon, } \\
\text { tons }\end{array}$ \\
\hline \multicolumn{2}{|l|}{ Input: } \\
\hline Coke ( 822 tons, $83 \% \mathrm{C}$ ) & 682 \\
\hline Fuel 0 il (60 tons, $87 \% \mathrm{C}$ ) & 60 \\
\hline Total & 742 \\
\hline \multicolumn{2}{|l|}{ Output: } \\
\hline Hot Metal (1622 tons, $4.3 \% \mathrm{C}$ ) & 70 \\
\hline Off Gas (by difference) & \\
\hline To stoves $(30 \%)$ & 202 \\
\hline Export $(70 \%)$ & 470 \\
\hline Total & $\overline{742}$ \\
\hline
\end{tabular}

Export Gas Composition:

\begin{tabular}{|c|c|c|c|}
\hline Component & mole\% & tons & $10^{6} \mathrm{scf}$ \\
\hline $\mathrm{CO}$ & 22 & 603 & 15 \\
\hline $\mathrm{CO}_{2}$ & 18 & 775 & 13 \\
\hline $\mathrm{H}_{2}$ & 4 & 8 & 3 \\
\hline $0_{2}$ & 2 & 63 & 1 \\
\hline $\mathrm{N}_{2}$ & 54 & $\underline{1470}$ & $\underline{38}$ \\
\hline Total & 100 & 2929 & 70 \\
\hline
\end{tabular}


TABLE 5. Estimated Carbon Balance for Blast Furnace \#4, December 4, 1979

Input:

Coke (1711 tons, 83\% C)

Fuel $0 i 1$ (120 tons, $87 \% \mathrm{C}$ )

Total

Output:

Hot Metal (2617 tons, 4.3\% C)

Off Gas (by difference)

To stoves $(30 \%)$

Export (70\%)

Total

Export Gas Composition:

\begin{tabular}{|c|c|c|c|}
\hline Component & mole\% & tons & $10^{6} \mathrm{scf}$ \\
\hline $\mathrm{CO}$ & 20.5 & 885 & 23 \\
\hline $\mathrm{CO}_{2}$ & 16.0 & 1085 & 18 \\
\hline $\mathrm{H}_{2}$ & 4.0 & 12 & 4 \\
\hline $0_{2}$ & 2.5 & 123 & 3 \\
\hline $\mathrm{N}_{2}$ & 57.0 & 2460 & 63 \\
\hline Total & 100.0 & 4565 & 111 \\
\hline
\end{tabular}

data supplied by Kaiser from a test of their BOP off-gas system and continuous stack gas analyzer with tighter operation of the hood. The peaks in the $\mathrm{CO}_{2}$ curve show the beginning and end of the period during which the hood was in its lowest position and combustion at the furnace was suppressed. If the off gas was to be utilized, it would be diverted to storage during that 10-min period on $7 y$.
1076

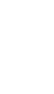

972

105

1076

Carbon,

tons 


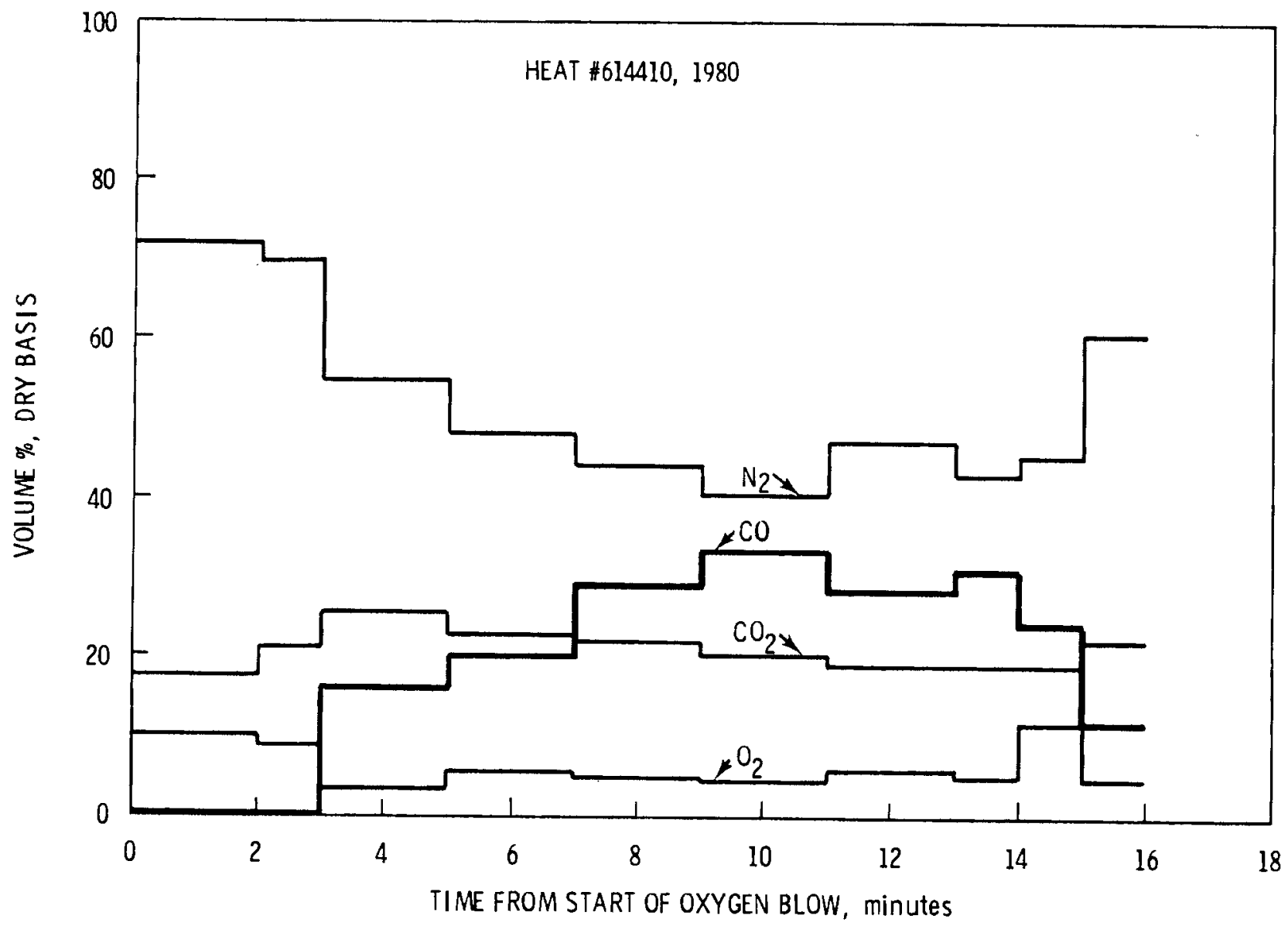

FIGURE 4. Off-Gas Concentrations, Basic Oxygen Furnace \#6, Heat \#614410, 1980

Kaiser Stee 1 has three blast furnaces in Fontana similar to \#3 and blast furnace \#4, which is larger. Virtually all of the pig iron these furnaces produce is processed through the basic oxygen process shop. The quantity and concentration of blast furnace gas available, downstream of the stoves, can be estimated for operation of all four furnaces at their average rates of 2030 tons of iron per day for \#4 and 1690 tons/day for \#1, \#2, and \#3 (K. A. Shearer, Kaiser Steel, personal communication 1980). The quantity and concentration of recoverable BOP gas for the same rate of pig iron production can also be estimated using data cited by Curtis (1976) for actual operation of a BOP gas recovery system. Table 6 presents such estimates of maximum availability of blast furnace and basic oxygen process gases at Fontana. Processing of 7100 tons of pig iron in a day would require the production of about 37 heats of steel. That rate of operation would be high for Kaiser's BOP shop. 


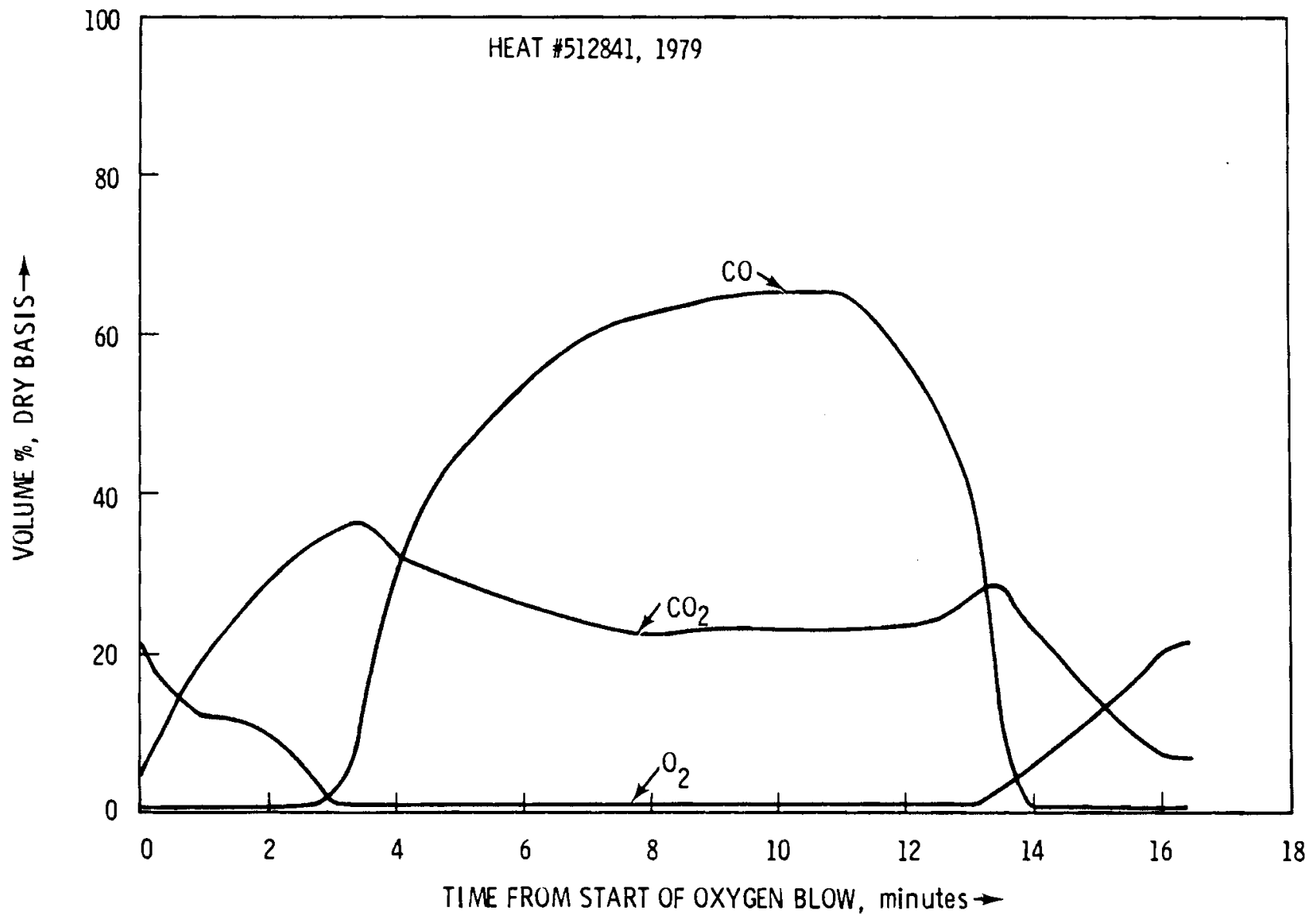

FIGURE 5. Off-Gas Concentrations, Basic 0xygen Furnace \#5 Heat \#512241, 1979

TABLE 6. Average Quantities and Concentrations of Carbon Monoxide and Hydrogen in Basic Oxygen Process and Blast-Furnace Gas, Fontana, Californiala)

$\begin{array}{lcccc}\frac{\text { Component }}{\text { Basic Oxygen Process }} & \begin{array}{c}\text { Concentration, } \\ \text { mole\% }\end{array} & & \text { Quantity } \\ \text { C0 } & 70 & & 475 & 12 \\ \text { Blast Furnaces } & 21 & & 10^{6} \text { scf /day } \\ \text { CO } & 4 & & 2570 & 66 \\ \mathrm{H}_{2} & & 34 & 12\end{array}$

(a) Based on operating rate of 7100 tons/day of pig iron. 


\section{AMMONIA}

Several processing schemes can be imagined for the production of ammonia using iron and steel byproduct gases. Coke-oven gas has approximately the composition of partially reformed methane. One simple scheme would be to "complete" the steam reforming reaction and proceed as in conventional synthesis from natural gas. As in the conventional process, air would be added to the feed of this "secondary" reformer to supply the proper amount of nitrogen, and the accompanying oxygen would burn part of the coke-oven gas providing some of the heat required to drive the reaction.

Separation of coke-oven gas into a stream of pure hydrogen and a methanerich fuel would carry the advantages of fewer processing steps and would provide a gaseous fuel that could be used to under-fire the coke ovens. The latter would be particularly significant in stand-alone coke plants where blast furnace gas would not be available for under-firing. Since the endothermic steam reforming reaction is not used, the heat from the combustion to remove oxygen from air, as a nitrogen source, could not be effectively used. Nitrogen could be imported as a feedstock or, in an integrated steel mill, the nitrogen content of other byproduct gases could be used. The former is apparently the route used by U.S. Steel in its coke-oven-based ammonia plants cited earlier.

Production of ammonia from coke-oven gas and purchased nitrogen is outlined in Figure 6. The "De 0xo" step is a catalytic reactor which removes the oxygen content of the coke-oven gas by reaction with hydrogen. Hydrogen separation could be cryogenic or could utilize a newer technology such as pressure swing adsorption. Figure 7 illustrates ammonia production from coke-oven gas with BOP and blast-furnace gas providing the nitrogen requirement and carbon monoxide as a source of additional hydrogen. The methanation step converts residual carbon monoxide and carbon dioxide to methane by reaction with hydrogen to prevent oxidation of the ammonia catalyst. The process is clearly more complex but has the advantage of utilizing BOP gas which is currently wasted in the U.S. Table 7 compares the estimated energy consumption for these two routes to ammonia with standard ammonia synthesis. The estimation is based on pressure swing adsorption and includes power for refrigeration. Total energy consumption is higher at an energy cost for power of $10,000 \mathrm{Btu} / \mathrm{kWh}$, but in an 
NITROGEN

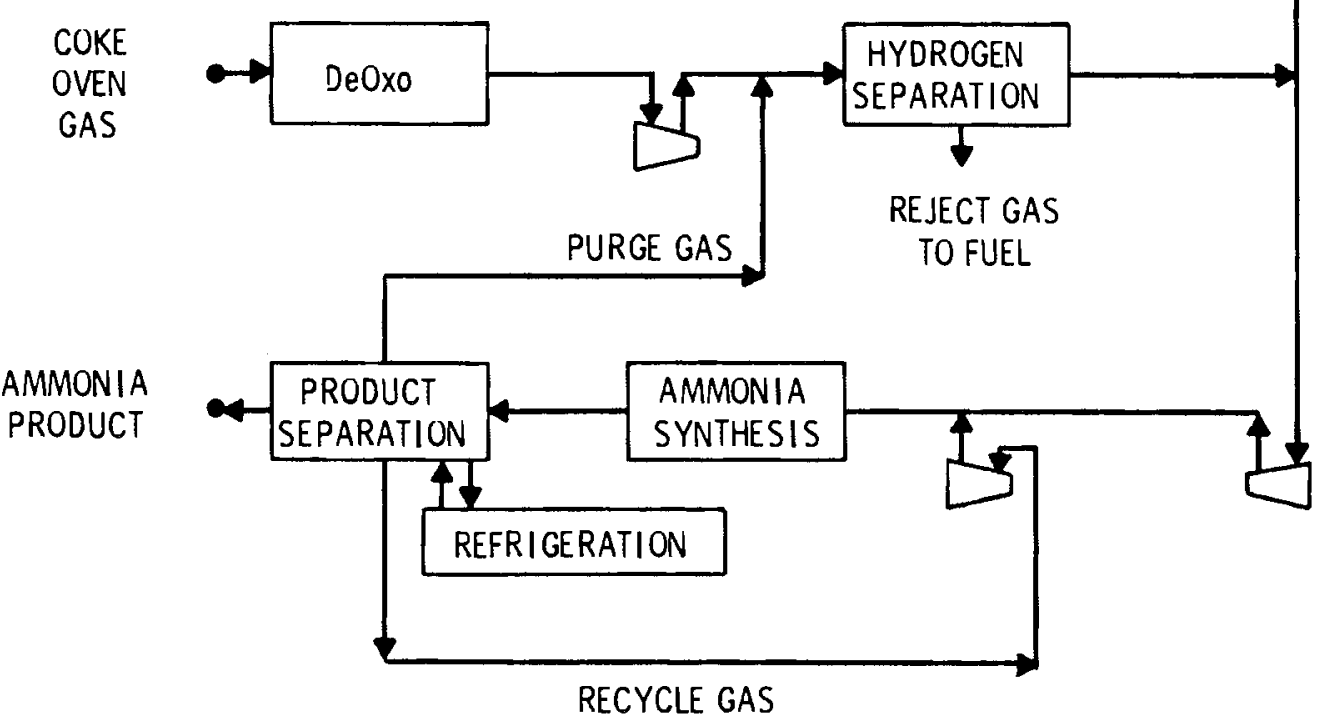

FIGURE 6. Ammonia from Coke-Oven Gas and Purchased Nitrogen

integrated plant a somewhat lower figure might be achieved. The conventional route generates all power internally. BOP gas provides $29 \%$ of the energy content of the feedstock and blast-furnace gas $9 \%$ for the case in which they are used.

New ammonia plants are being constructed at a minimum capacity per stream of 1000 tons/day. The coke-oven gas plus nitrogen option would require cokeoven gas equivalent to 18,000 tons/day of pig iron production for a 1000-ton/ day ammonia plant. The coke-oven plus BOP plus blast-furnace gas option would require gases equivalent to an 11,000-tons/day pig iron operation for such a plant. In the former case, simplicity of the process and in the latter the use of lower value feedstocks may allow smaller plants to be competitive. 


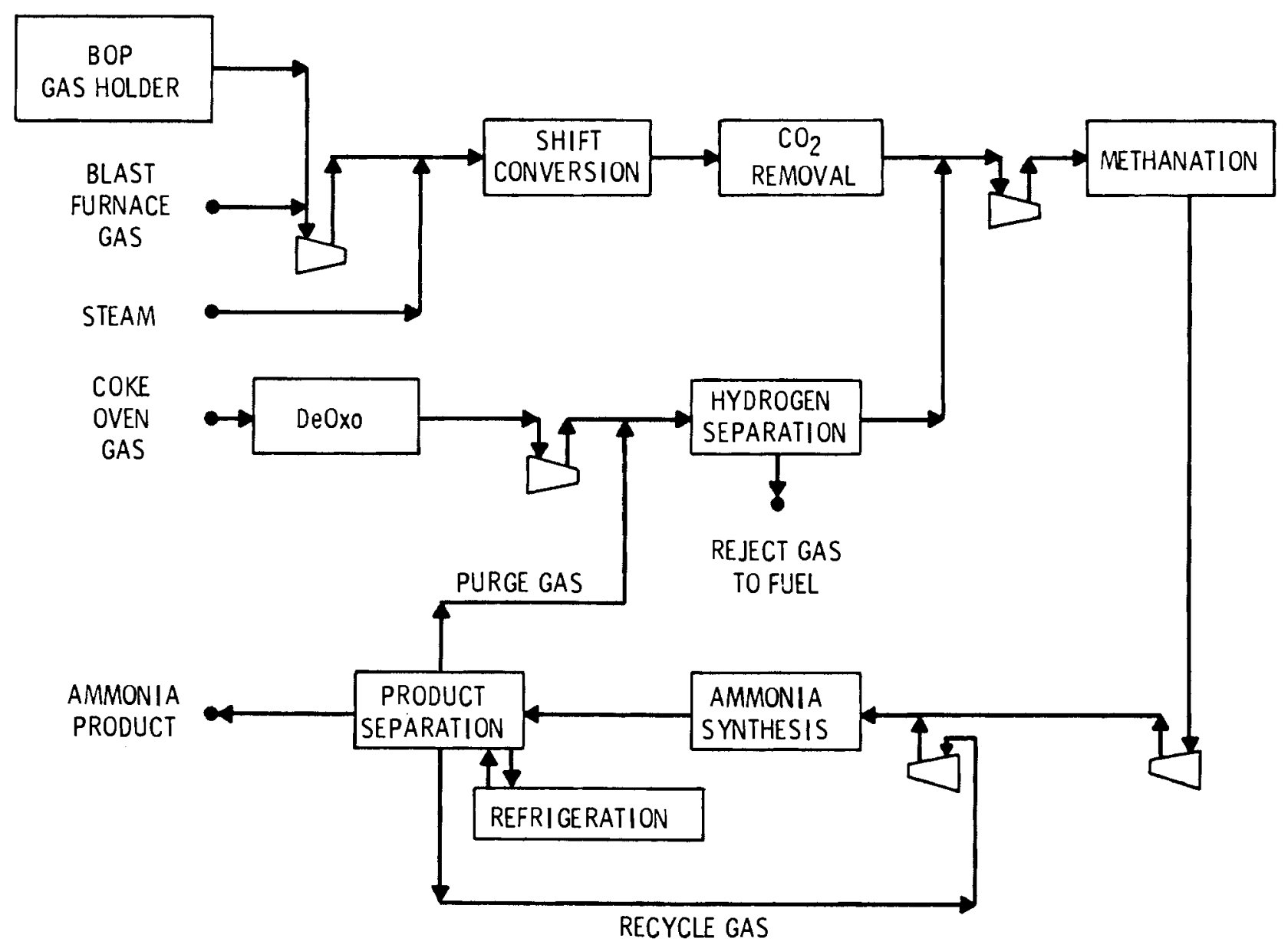

FIGURE 7. Ammonia From Coke-Oven, Basic Oxygen Process and Blast-Furnace Gas

TABLE 7. Energy Consumption for Ammonia Synthesis

\begin{tabular}{|c|c|c|c|}
\hline Process Feedstock (s) & $\begin{array}{c}\text { Natural } \\
\text { Gas }\end{array}$ & $\begin{array}{l}\text { Coke- } \\
\text { Oven } \\
\text { Gas } \\
\quad+ \\
\text { Nitrogen }\end{array}$ & $\begin{array}{c}\text { Coke-Oven Gas } \\
+ \\
\text { Basic Oxygen Process Gas } \\
+ \\
\text { Blast-Furnace Gas }\end{array}$ \\
\hline Feed and Fuel, $10^{6} \mathrm{Btu} /$ ton & 31.0 & 20.0 & 20.5 \\
\hline $\begin{array}{l}\text { Power, kwh/ton } \\
\qquad\left(10^{6} \text { Btu/ton }\right)(a)\end{array}$ & -- & $\begin{array}{l}1210 \\
(12)\end{array}$ & $\begin{array}{l}1410 \\
(14)\end{array}$ \\
\hline Nitrogen, $10^{3} \mathrm{scf} /$ ton & -- & 21.5 & -- \\
\hline
\end{tabular}

(a) 10,000 Btu/kWh 
METHANOL

The production of methanol with steel mill gases could be accomplished by using BOP and/or blast-furnace gases as sources of carbon and coke-oven gas as a source of hydrogen. Maximum methanol output from a given steel operation would result from steam reforming coke-oven gas to a mixture of $\mathrm{CO}, \mathrm{CO}_{2}$ and $\mathrm{H}_{2}$ and using $\mathrm{CO}$ and $\mathrm{CO}_{2}$ separated from $\mathrm{BOP}$ and/or blast-furnace gases to provide the carbon required for the synthesis gas. A potentially simpler approach, however, that would be less demanding of already-utilized gases would be to make the required synthesis gas by separating carbon monoxide from BOP gas and hydrogen from coke-oven gas. This would take advantage of the synthesis gas components already present in the byproduct gases and eliminate the steam reforming of methane. The remaining coke-oven gas would be rich in methane and could be used in the steel mill fuel system.

Figure 8 illustrates a scheme for production of methanol from BOP and coke-oven gas. The "De 0xo" step is a catalytic reactor which removes the oxygen in the coke-oven gas by reaction with hydrogen. After combination of carbon monoxide (and some carbon dioxide) from the BOP gas with hydrogen from the coke-oven gas, the methanol synthesis is standard. Table 8 compares estimated energy consumption for methanol production from BOP and coke-oven gas with conventional processing. The estimation is based on pressure swing adsorption for hydrogen separation and $\mathrm{COSORB}^{\circledR}$ for carbon monoxide separation. While the conventional process derives all power for compression and circulation from steam turbines, the estimate for the byproduct-gas-based process shows this power requirement separately. The total energy consumption would depend on the specific design of a plant. The latter process derives $31 \%$ of the energy content of its feedstock from BOP gas, which is currently not utilized in the United States.

Methanol producers are constructing new plants at a minimum capacity per stream of 1000 tons/day. The BOP plus coke-oven gas process would require a steel mill to process 13,000 tons/day of pig iron through its BOP to provide sufficient gas for a 1000-ton/day methanol plant. The largest U.S. basic oxygen process shop with suppressed combustion is in United States Steel's Fairfield Works. It has a steel capacity of 3.2 million ton/yr. If that shop 


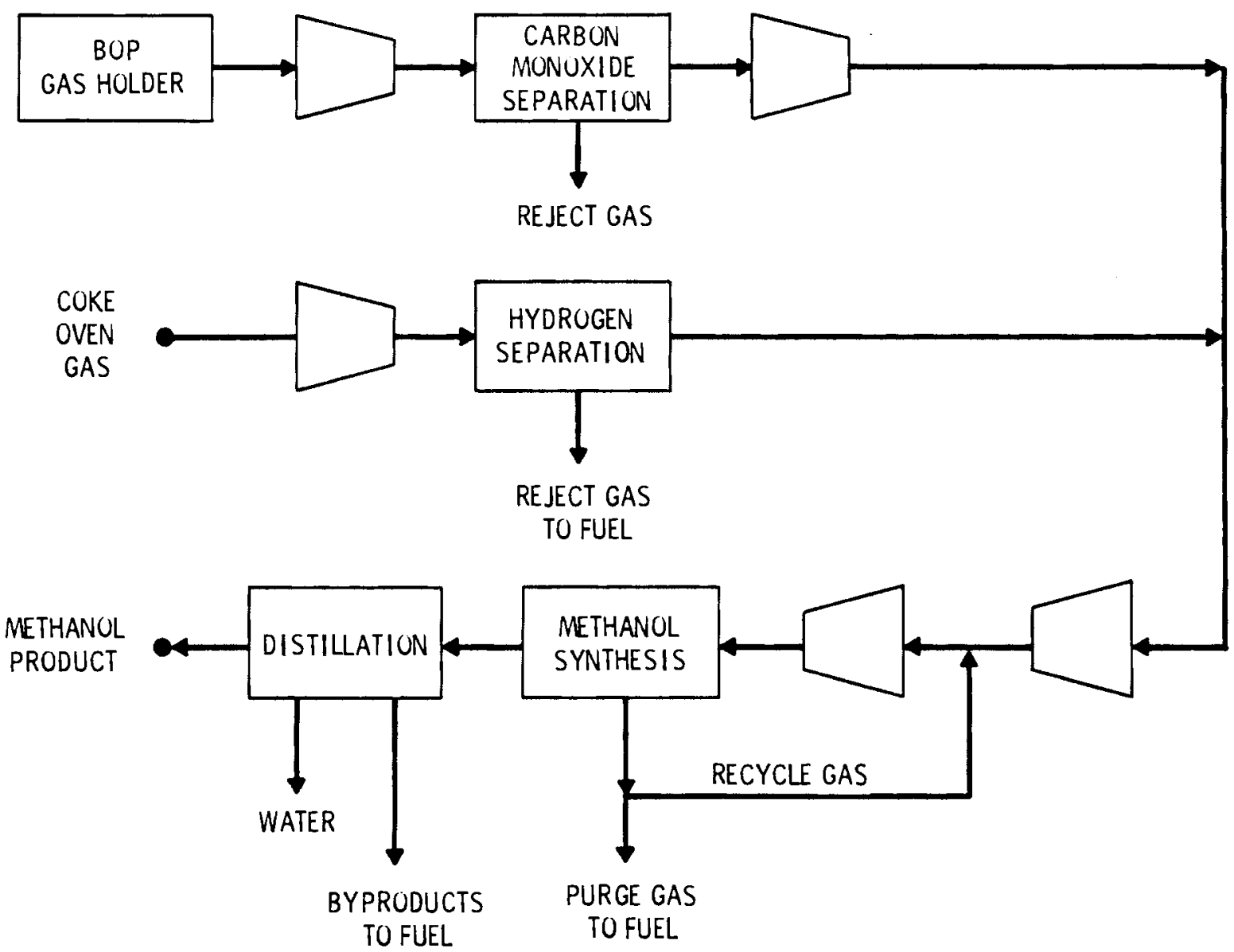

FIGURE 8. Methanol from Basic 0xygen Process and Coke-Oven Gas

TABLE 8. Energy Consumption for Methanol Synthes is

\begin{tabular}{|c|c|c|}
\hline Process Feedstock & $\begin{array}{c}\text { Natural } \\
\text { Gas }\end{array}$ & $\begin{array}{c}\text { Basic Oxygen Process } \\
+ \\
\text { Coke-Oven Gas } \\
\end{array}$ \\
\hline Feed + Fue $1,10^{6}$ Btu $/$ ton & 30.6 & 24.6 \\
\hline $\begin{aligned} \text { Power, } & \mathrm{kWh} / \text { ton } \\
& \left(10^{6} \mathrm{Btu} / \text { ton }\right)(\mathrm{a})\end{aligned}$ & -- & $\begin{array}{l}950 \\
(9.5)\end{array}$ \\
\hline
\end{tabular}

(a) e $10,000 \mathrm{Btu} / \mathrm{kWh}$ 
operated at capacity using $80 \%$ pig iron feed, it would process 7000 ton/day producing sufficient gas for about a 500-ton/day methanol plant. For a plant of that size capital cost per unit capacity for the methanol synthesis and distillation steps would be higher than for a conventional plant due to unfavorable economics of scale. The natural gas reformer, however, would be replaced by the $\operatorname{COSORB}^{\circledR}$ and pressure swing adsorption steps which might require less capital. For a tightly operated BOP with low nitrogen content in its byproduct gas (less than $10 \%$ ) the $\operatorname{COSORB}^{\circledR}$ process might be eliminated. In that case, investment per unit capacity could possibly be less than for a conventional plant.

\section{HYDROGEN}

Both ammonia and methanol production seem likely to require larger amounts of off gas than are likely to be available at Kaiser Steel's Fontana plant in the immediate future. Hydrogen, however, can be profitably produced at smaller scales. This section explores the production of hydrogen from coke-oven gas with specific attention to the Fontana location.

Most of the hydrogen produced in the United States is used directly by the producer in ammonia or methanol manufacture or in petroleum refining (Berry 1980; Bassett and Natarajan 1980). About 4\% of the demand for hydrogen, however, is for smaller uses, and a portion of that part of the demand is supplied by merchant hydrogen producers. Forecasters put 1980 merchant hydrogen production at 47.8 billion $\mathrm{ft}^{3}$ with $63 \%$ used in chemical processing and the remainder finding metallurgical uses (Fallwell and Greek 1980). On the West Coast, the space program and the electronics industry are major markets for merchant hydrogen in addition to some of the more conventional uses. Two producers of liquid hydrogen located in the Los Angeles area serve this market with a total production capacity of about 40 million $\mathrm{ft}^{3}$ per day (McHugh 1980).

A flowsheet for the separation of hydrogen from coke-oven gas is presented in Figure 9 and Table 9. Pressure swing adsorption was chosen for developing the flowsheet as a likely candidate technology. Cryogenic separation and Monsanto's "Prism" technology should, however, also be considered by prospective hydrogen producers. In the pressure swing adsorption process, a 


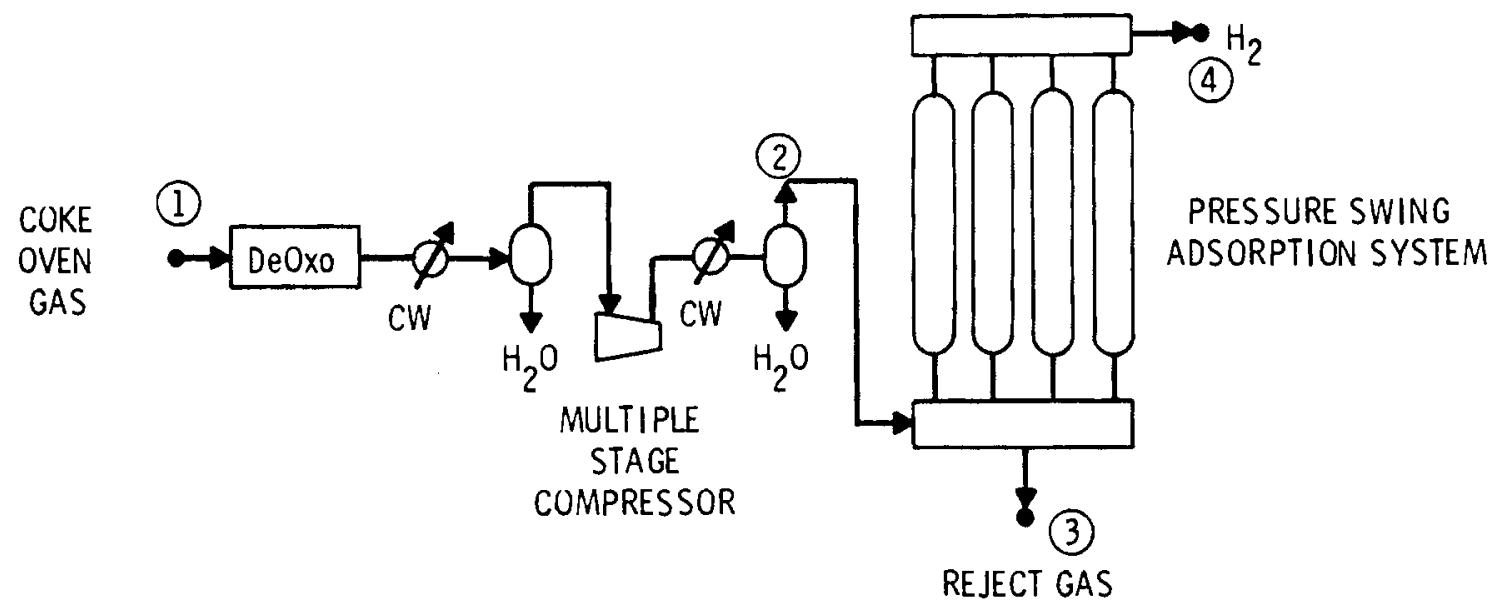

FIGURE 9. Hydrogen Production from Coke-Oven Gas: Flow Diagram

TABLE 9. Hydrogen Production from Coke-Oven Gas: Material Balance

\begin{tabular}{|c|c|c|c|c|c|c|c|c|}
\hline \multirow[b]{2}{*}{ Component } & \multicolumn{2}{|c|}{$1(a)$} & \multicolumn{2}{|c|}{$2(a)$} & \multicolumn{2}{|c|}{$3(a)$} & \multicolumn{2}{|c|}{$4(a)$} \\
\hline & $10^{6} \mathrm{scf}$ & mole\% & $10^{6} \mathrm{scf}$ & mole\% & $10^{6} \mathrm{scf}$ & mole\% & $10^{6} \mathrm{scf}$ & mole\% \\
\hline $\mathrm{H}_{2}$ & 1.35 & 52 & 1.25 & 51 & 0.25 & 17 & 0.999 & 99.9 \\
\hline CO & 0.16 & 6 & 0.16 & 6 & 0.16 & 11 & 0 & 0 \\
\hline $\mathrm{CO}_{2}$ & 0.05 & 2 & 0.05 & 2 & 0.05 & 4 & 0 & 0 \\
\hline $\mathrm{CH}_{4}$ & 0.65 & 25 & 0.65 & 27 & 0.65 & 45 & 0 & 0 \\
\hline$c_{2}+$ & 0.08 & 3 & 0.08 & 3 & 0.08 & 5 & 0 & 0 \\
\hline $\mathrm{N}_{2}$ & 0.26 & 10 & 0.26 & 11 & 0.26 & 18 & 0.001 & 0.1 \\
\hline $\mathrm{O}_{2}$ & 0.05 & 2 & 0.0 & 0 & 0.0 & 0 & 0 & 0 \\
\hline Tota 1 & 2.60 & 100 & 2.45 & 100 & 1.45 & 100 & 1.00 & 100 \\
\hline LHV $10^{6} \mathrm{Btu}$ & & & & 27 & & & & \\
\hline Pressure, psig & 1 & & & & 3 & & & \\
\hline
\end{tabular}

(a) Stream number from Figure 9.

hydrogen-rich gas passes through one of several adsorbent beds which removes virtually all types of impurities with on ly a minor pressure drop from feed to product. When the bed is loaded with impurities the feed is switched to another bed and the loaded bed is regenerated by depressurization and purging on a timed cycle transferring gas between beds to minimize losses. The driving 
force for the separation is the production of a purge or reject gas at a low pressure (sufficient for fuel supply) with less than $100 \%$ hydrogen recovery ( $80 \%$ to $90 \%$ is typica 1 ). This is ideal for production of hydrogen from cokeoven gas where a fuel use exists for the reject gas and high hydrogen yield is not required. The Linde Divison of Union Carbide Corporation has built several 4-bed pressure swing adsorbtion systems integrated with steam reformers to produce hydrogen where the reject gas is used as reformer fuel (Union Carbide 1975). More recently the HYSIV ${ }^{\circledR}$ polybed pressure swing adsorbtion system has been developed which becomes more economical for capacities greater than $10^{7} \mathrm{scf} /$ day and can achieve high hydrogen recoveries (Heck and Johansen 1978). According to J. L. Heck of Union Carbide, one plant in Europe is operating on coke-oven gas (personal communication 1980).

Referring again to Figure 9 and Table 9, the coke-oven gas composition is from data provided by Kaiser for the ir gas. The "De 0xo" step removes oxygen from the feed gas by reaction with hydrogen. The pressure of 300 psig represents a minimum requirement of the process to achieve the design hydrogen recovery of $80 \%$. In order to avoid tar accumulation problems, the dew point of hydrocarbons in the gas must not exceed $40^{\circ} \mathrm{F}$ at the operating pressure. From the breakdown of the higher hydrocarbon fraction supplied by Kaiser, only the benzene-toluene-xylene (BTX) component could exceed this criteria. According to a further breakdown of the BTX fraction for a typical coke-oven gas (McGannon 1971), however, the criteria would not be exceeded. The possibility remains of some minor tar problems, since Kaiser's breakdown shows $300 \mathrm{ppm}$ of other light oil components that could be below their dew point. The $\mathrm{H}_{2} \mathrm{~S}$ level in Kaiser's data is above the $0.2 \mathrm{~g} / \mathrm{m}^{3}$ maximum for pressure swing adsorbtion (communication with J. L. Heck 1980), but a lower level may be present in the gas currently produced in Fontana.

The energy consumption for the process of Figure 9 and Table 9 including power to drive the compressor is listed in Table 10. Energy requirements for conventional reforming of a naptha feedstock to produce hydrogen are listed for comparison (Heck and Johansen 1978). Adjusting capital cost data from the same

(8) HYSIV is a registered trademark of Union Carbide Corporation. 
TABLE 10. Energy Consumption for Hydrogen Production

\begin{tabular}{|c|c|c|}
\hline $\begin{array}{c}\text { Feedstock } \\
\text { Process }\end{array}$ & $\begin{array}{c}\quad \text { Naptha } \\
\text { Conventional } \\
\text { Reforming } \\
\end{array}$ & $\begin{array}{l}\text { Coke-Oven Gas } \\
\text { Pressure Swing } \\
\text { Adsorption } \\
\end{array}$ \\
\hline Feed + Fuel, Btu/scf & 403 & 304 \\
\hline $\begin{aligned} & \text { Power, } \text { kWh } / 10^{6} \text { scf } \\
&(B t u / s c f) \\
&(a)\end{aligned}$ & $\begin{array}{l}440 \\
(4.4)\end{array}$ & $\begin{array}{l}11,100 \\
(111)\end{array}$ \\
\hline
\end{tabular}

(a) o $10,000 \mathrm{Btu} / \mathrm{kWh}$

source to a $30 \times 10^{6}$-scf/day plant, compatible with the amount of hydrogen that could be recovered from coke-oven gas at Fontana, gives an investment of $\$ 15$ million at 1980 construction costs. J. L. Heck estimates the cost of the pressure swing adsorbtion system in Figure 9 at $\$ 4$ to $\$ 5 \mathrm{million}$ for the same capacity. The compressor would be another major cost item, but PNL estimates that the total investment for a $30 \times 10^{6}$-scf/day hydrogen recovery plant would not exceed $\$ 10$ million.

One of the West Coast producers of liquid hydrogen is Union Carbide Corporation with a plant located less than $10 \mathrm{mi}$ from Fontana. They produce hydrogen by reforming natural gas. A gas separation plant in Fontana might replace Union Carbide's reformer or, if the potential for growth in the liquid hydrogen market is sufficient, additional liquefaction capacity could be added. Another possibility would be construction of a pipeline to carry gaseous hydrogen along the natural gas right-of-way toward Los Angeles. Such a line could easily reach sufficient petroleum refiners to consume a $30 \times 10^{6}$-scf/day output. Although most refiners make their own hydrogen, the increasing need for hydrogen to process heavy, high-sulfur crude oil could make such an approach feasible.

\section{OTHER CHEMICALS}

Carbon monoxide separated from BOP off gas could be attractive for production of the same group of chemicals that was discussed under "Other Chemicals" in the elemental phosphorus section of this report. Carbon monoxide from BOP 
off gas is potentially available in similar quantities per site but at lower concentrations. The off gas must also be accumulated in a gas holder to achieve a steady supply. These factors must be traded off against the opportunity to use a resource that is currently wasted.

Stee 1 mills have the attractive feature of having hydrogen-rich coke-oven gas in the same vicinity as carbon monoxide-rich BOP off gas. This feature fits well with isocyanate production which requires carbon monoxide to react with chlorine to make phosgene and, in a separate step, hydrogen to react with an organic nitrate to make the required amine, if it is not imported. Any of the chemicals in Table 2 could also be considered as well as some that use only hydrogen; however, as explained in the elemental phosphorus section of this report, assessment of market factors would be particularly important for the smaller-volume chemicals that use other expensive feedstocks besides synthesis gas. Furthermore, steel mills generally have more uses for gaseous or liquid feeds than they have byproduct gas available which raises the cost of the byproduct gases. If a plant to produce one of those chemicals was to be located in the vicinity of a stee $1 \mathrm{mill}$, however, byproduct carbon monoxide or hydrogen might be supplied at a lower cost than that of producing them at the plant.

\section{INDIRECT USE OF BYPRODUCT GASES}

Most steel mills have byproduct coke breeze and other sources of finely divided carbon which is difficult to utilize. Two steel producers suggested schemes involving the use of such solid byproducts in combination with byproduct gases for review by PNL.

Kaiser Steel suggested that blast-furnace gas might be recycled if its carbon monoxide content could be increased. Natural gas or fuel oil is commonly injected at blast furnace tuyeres along with the blast air as a means of conserving coke. A carbon monoxide-rich gas could replace the natural gas or $0 i 1$ as well as the blast air required to react with it. The required composition to match the performance of the injected fuel can be estimated by assuming that the fuel reacts with air to form reducing gas as follows: 


$$
\mathrm{CH}_{4}+\frac{1}{2} \mathrm{O}_{2}+2 \mathrm{~N}_{2} \rightarrow \mathrm{CO}+2 \mathrm{H}_{2}+2 \mathrm{~N}_{2}
$$

The reaction product contains $20 \% \mathrm{CO}$ and $40 \% \mathrm{H}_{2}$ so the target composition would be $60 \% \mathrm{CO}+\mathrm{H}_{2}$.

The method suggested by Kaiser to enrich blast-furnace gas was to react it with byproduct carbon to convert its $\mathrm{CO}_{2}$ content to $\mathrm{CO}$. The reaction would be:

$$
\mathrm{CO}_{2}+\mathrm{C}+2 \mathrm{CO}
$$

which is endothermic and must, therefore, be driven by a source of heat. That heat could be supplied by adding air to burn a portion of the carbon. Simple heat and material balances for gasification of carbon in air plus a typical blast-furnace gas show that a maximum $\mathrm{CO}+\mathrm{H}_{2}$ content of only $41 \%$ could be achieved. A richer gas could be obtained by replacing some of the air with oxygen; but in that case, steam gasification, eliminating the blast-furnace gas, would make better use of the valuable oxygen. Reducing gas has been generated in the past by alternately passing air and then steam through a fixed bed of carbon. In the air stage, the carbon is heated; and in the steam stage the heat drives the endothermic steam gasification reaction. The same approach could be used with carbon dioxide in blast-furnace gas replacing the steam, except that finely divided carbon could not be used as it would plug the fixed bed. In that case $\mathrm{CO}+\mathrm{H}_{2}$ contents approaching $53 \%$ could be achieved.

The minimum concentration for profitable injection of reducing gas at blast furnace tuyeres should be more carefully determined. If no viable scheme using blast-furnace gas is possible, steam-oxygen gasification of byproduct carbon may still be feasible. It should also be noted, as suggested by Kaiser, that injection into a blast furnace is an alternate use for BOP off gas which may already have the required carbon monoxide concentration.

Inland Steel suggested use of the reaction of carbon dioxide with byproduct carbon as a part of a scheme to generate a steady stream of carbon monoxide-rich gas. The scheme would utilize BOP off gas without using gas-holding 
equipment. Three retired blast furnace stoves would be used to store heat from the combustion of BOP off gas. That heat would then be used to drive the endothermic reaction of byproduct carbon with carbon dioxide derived from another byproduct gas stream. Blast furnace stoves are large, insulated vessels filled with a refractory brick (checker work) which is alternately heated, by combustion of blast-furnace gas, and cooled, while preheating blast air.

The available stoves have been used to supply $85,000 \mathrm{scf} / \mathrm{min}$ of air preheated to $1700^{\circ} \mathrm{F}$. Inland suggested that higher temperatures would be possible by using different checker work. Comparison of the rate of heat delivery for which the stoves were designed with the average rate of heat released by combustion of the off gas from Inland's suppressed combustion BOP shop showed the stoves to be a good match. The instantaneous rate at which that heat would have to be stored during the period when combustible BOP off gas would be available, however, would be about twice the maximum rate at which the stoves stored heat in the service for which they were designed. The high rate of temperature change in the stoves might cause problems through thermal shock.

A simple heat and material balance calculation shows that using the heat from the stoves to preheat pure carbon dioxide for a single-stage reaction with carbon would not be effective. Even if the carbon dioxide could be preheated to $2000^{\circ} \mathrm{F}$, only a $20 \%$ carbon monoxide product could be achieved before the gas temperature would drop to the minimum reaction temperature of $1500^{\circ} \mathrm{F}$. More heat could be supplied to the reaction by multiple stages of reheat but several more stoves would be needed. Alternatively, a heat transfer media could be used but heat transfer at the required temperature would pose formidable materials problems. The simplest solution would be to add oxygen or air to supply the remainder of the heat by burning a portion of the carbon.

The proposed process is illustrated by Figure 10. A mathematical description was developed for gasification of carbon that could take into account the effect of preheating carbon dioxide, steam (if used), or oxygen. The effectiveness of the use of BOP off-gas combustion heat can be evaluated in terms of the savings in oxygen consumption it causes relative to gasification with ordinary preheat temperatures (taken here as $1000^{\circ} \mathrm{F}$ ). From preheat of both air and carbon dioxide to $2000^{\circ} \mathrm{F}$, a $15 \%$ savings would result, and preheat to $2300^{\circ} \mathrm{F}$ 
RETIRED BLAST FURNACE STOVES

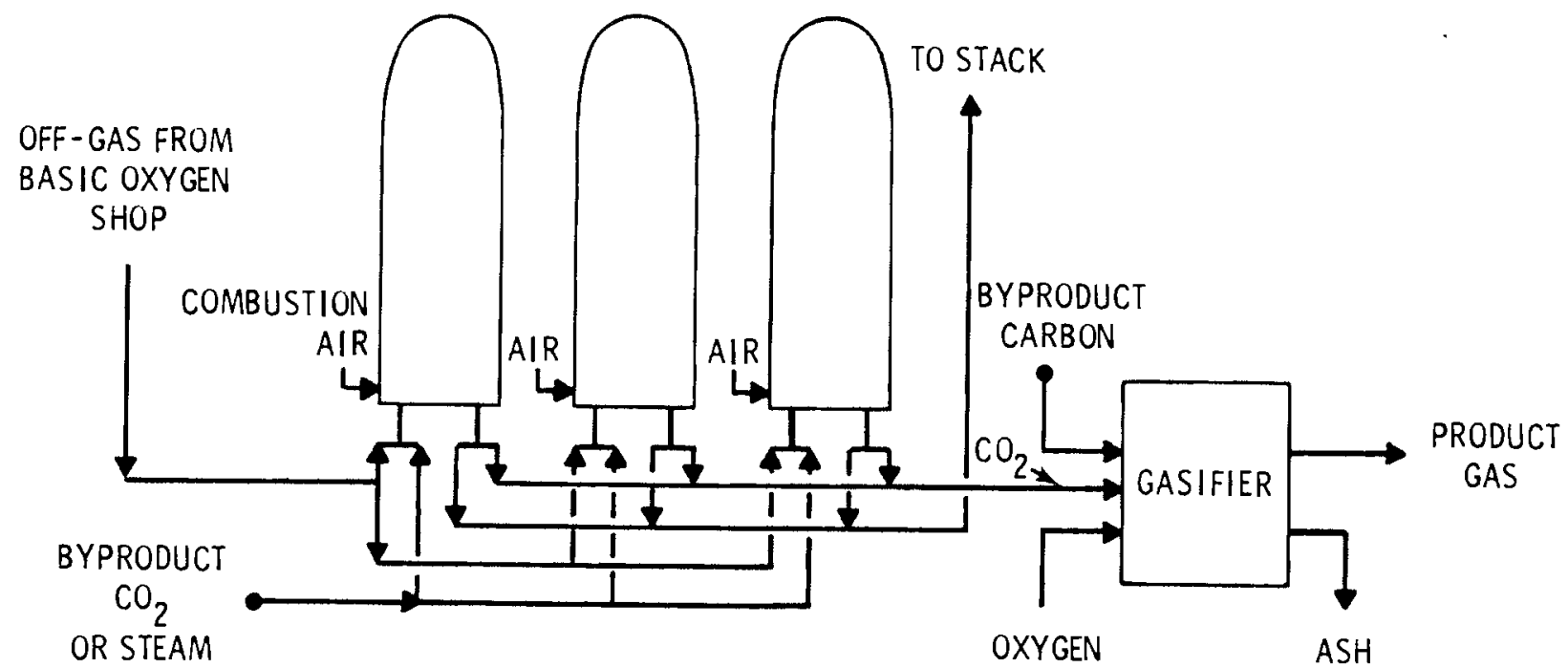

FIGURE 10. Use of Basic Oxygen Process Off Gas to Supply Heat for Carbon Gasification

would increase the oxygen savings to $20 \%$. Similar results were found for the use of steam in place of carbon dioxide. It is not likely that savings of that magnitude could justify a BOP off-gas utilization venture. It should also be noted that using this scheme to utilize all of the heat available from a BOP producing 2.4 million tons of stee 1 annually would require a relatively large gasifier that would consume about 860 ton/day of waste carbon. The concept of gasification to recover the heating value of finely divided carbon, however, remains promising.

The combination of the ideas of Kaiser Steel and Inland Steel may be worth investigating. The nitrogen content of blast-furnace gas would offer an advantage by carrying more heat into the reactor from the stoves. The addition of supplementary carbon dioxide or steam might allow $\mathrm{CO}+\mathrm{H}_{2}$ concentrations to be reached that would be useful for injection at blast furnace tuyeres.

OUTLOOK

The iron and steel industry is both a prolific producer and a prolific consumer of byproduct gases. McGannon (1971) lists the following steel plant applications as being best satisfied by gaseous fuels: coke-oven heating, 
blast-furnace stoves, gas turbines for power generation, gas engines for blowing or power generation, soaking pits, reheating furnaces, forge and blacksmith furnaces, normalizing and annealing furnaces, controlled-cooling pits, foundry core ovens, blast-furnace and steel-ladle drying, drying of blast-furnace runners and open-hearth tapping spouts, and hot-top drying. It is easy to see why steel producers buy substantial amounts of liquid and gaseous fuels to supplement the ir byproduct gases. A study reported by Paxton (1977) showed that a highly efficient steel plant could reduce its fuel gas requirements to $75 \%$ of its byproduct gas production. This plant, however, would have to use several new energy conservation measures some of which may not be cost effective. In 1979, the use of byproduct gas fuels by the iron and steel industry was only $44 \%$ of its total gaseous and 1 iquid fuel consumption (American Iron and Steel Institute 1980).

The high demand for gaseous fuels in a steel plant means that any chemical production scheme would have to be able to pay more than fuel value for its byproduct gas feedstock. This is true even of BOP off gas, which is not currently utilized, since the fuel use alternative would be available once the gas is collected.

Analysis of both ammonia and methanol production from byproduct gases showed that consumption of fuel per unit of chemical product would be about the same as for conventional production, when the fue 1 required to generate power is included. For a scale of production that is possible at a few steel mills, however, it appears possible that capital costs may be lower for byproductgas-based plants than for those using conventional feeds. Because the production of both ammonia and methanol is capital intensive, reduced capital cost would mean that a higher price might be paid for the byproduct gases as feedstocks than as fuel.

Similarly, for hydrogen production from coke-oven gas, total energy consumption would be similar to conventional hydrogen production and lower capital costs appear possible. In the case of hydrogen, lower capital costs seem more certain and likely to occur at a scale of production that is possible at several steel mills across the country. Hydrogen production at commercial scales, however, is not as capital intensive as ammonia and methanol production. For 
all three products the effect of the higher power component and lower fuel component in the energy requirements for production from byproduct gas should be considered relative to utility costs at any particular site.

Several other chemicals require pure carbon monoxide in their production routes. Production of such chemicals may be able to pay more than fuel value for BOP off gas because all of its fuel value is in the form of carbon monoxide and dilution by nitrogen is not high. These chemicals include acetic acid, the isocyanates, formic acid and oxalic acid. It seems likely that even fuel value may become sufficient incentive to collect BOP off gas in the near future if it is not already. The study of BOP off-gas utilization reported by the American Iron and Stee 1 Institute in 1976 quoted an installed cost of $\$ 6.3$ million for a 2-million- $\mathrm{ft}^{3}$ gas holder. A quotation received from GATX Tank Erection Corporation in 1980 indicates that that cost has not increased significantly. Fuel costs, on the other hand, are rising at a rate that leads inflation.

Implementation of the ideas in this study will require that steel producers get in touch with chemical producers to combine their knowledge of byproduct gas availability, composition and costs, power costs, chemical processing technology, and chemical markets. In the case of the ideas discussed under "Indirect Use of Byproduct Gases" the on ly know-how steel producers may need to import would be in the area of gasification technology. 



\section{CARBON MONOXIDE SEPARATION FROM GAS STREAMS}

\section{BY MEANS OF PERMSELECTIVE MEMBRANES}

Carbon monoxide is a component of the effluent gases of many industries, particularly iron and steel, phosphorus, calcium carbide, some organic chemicals, etc. In total, waste carbon monoxide, if recovered, could be a major source for fuel or chemical feedstocks. In addition to this potential use, there would be a direct savings in natural gas usage since dilute carbon monoxide waste streams are currently rendered innocuous by burning them with natural gas and air (the carbn monoxide itself being too dilute to burn without the addition of natural gas).

There are three major methods currently used to separate carbon monoxide from mixtures with other gases--Cuprammonium, COSORB ${ }^{\circledR}$, and cryogenic methods. All three suffer from disadvantages--the first two because of the need to use toxic chemicals and the slow degradation of the trapping solution, and the cryogenic methods because of the need to liquefy the gas and the energy cost involved in doing this. Consequently, only the most concentrated carbon monoxide waste streams are treated for recovery of the carbon monoxide.

Very dilute carbon monoxide streams are oxidized catalytically with air simply to destroy the carbon monoxide and not for energy recovery. Moderate strength streams are mixed with natural gas and burned, as mentioned above.

A new separation process is needed that is applicable to carbon monoxide, preferably one that does not suffer from the disadvantages of a requirement for toxic chemicals or high energy use. A potential process has been demonstrated in the separation of carbon monoxide from hydrogen (McCandless 1972). The process is based on gas diffusion through a polymeric membrane. Since, according to Graham's Law, the rate of gas diffusion is inversely proportional to the square root of the molecular weight, and the molecular weights of carbon monoxide and hydrogen are 28 and 2, respectively, then the rates of diffusion of carbon monoxide and hydrogen will be in the ratio of $\sqrt{1 / 28}$ to $\sqrt{1 / 2}$, or $0.19: 0.70$. Given slightly differently, hydrogen will diffuse at a rate $3.7 x$ faster than carbon monoxide. It is likely that this ratio of separation can be improved by using particular chemical techniques such as selective polymeric 
membranes or by using a series of membranes. In fact, in the referenced article by McCandless, a separation factor of 70 was achieved using a $1 / 1$ mixture of hydrogen and carbon monoxide and a polyimide film.

The most common mixtures of carbon monoxide in waste gas streams are with oxygen, nitrogen, water vapor, sulfur dioxide, and the like, rather than with hydrogen. Nitrogen is by far the most common. Since both nitrogen and carbon monoxide have molecular weights of 28 , no separation at all would be expected by permitting a mixture of the two to diffuse through a membrane if a completely inert membrane were used.

The membrane separation method outlined above is an example of a passive separation; that is, there is no chemical change involved (no interaction between the membrane and diffusing species). Thus, the separation is achieved entirely on the basis of differences in physical properties. On the other hand, the $\operatorname{COSORB}^{\circledR}$ and cupramonium separation processes are strictly active in that they depend on a chemical reaction to separate nitrogen and other gases from carbon monoxide.

Diffusive permeation of a membrane occurs via following steps:

- impingement on and absorption of the permeant into the polymer barrier (this absorption may involve interaction between the barrier and permeant),

- diffusion of the permeant across the barrier (driven by a concentration gradient or chemical potential), and

- desorption of the permeant from the barrier into the environment beyond.

Techniques for studying the permeability and selectivity of polymeric barriers to gases are well defined and developed. The mathematical theory of diffusion has a firm basis in Fick's first and second laws (Fujita 1961; Crank and Park 1968). The theory of diffusion in isotropic substances indicates that the rate of transfer of a diffusing species through unit area of a membrane is proportional to the concentration gradient measured normal to the barrier. Equation (1) is commonly referred to as Fick's first law 


$$
Q=-D \frac{\partial C}{\partial x}
$$

where $Q$ (flux) is the rate of permeation of the diffusing species in mass per unit time per unit area, $D$ is the diffusion coefficient (or diffusivity) and $\frac{\partial C}{\partial x}$ is the concentration $(C)$ gradient of the permeant in the $x$ direction, normal to the membrane surface. If the concentration gradient across the membrane remains constant by providing a large reservoir of permeant at one surface and a complete permeant sink at the other surface, the transport of the permeant at equilibrium will be zero order; and integration of the above equation gives

$$
Q=\frac{D C_{1}}{\ell}
$$

where $C_{1}$ becomes the concentration of the permeant in the polymer in equilibrium with the permeant concentration in the reservoir or upstream face and $l$ is the thickness of the membrane.

The fundamental differential equation of diffusion is derived from Equation (1) and is known is Fick's second law

$$
\frac{\partial C}{\partial t}=\frac{22 C}{\partial x^{2}}
$$

in which form diffusion is assumed to be one-dimensional (in the $x$ direction) and $D$ is assumed to be a constant.

Fick's second law is satisfied by the experimental conditions used in one of the best developed methods for determining diffusion coefficients--the timelag technique (Daynes 1920; Barrer 1939). This technique uses the second law to determine diffusion coefficients by operating in the nonsteady state and also yields permeability coefficients, $P$, by later achieving a quasi-steady state. 
Once steady-state flux is attained at constant temperature, it is assumed that thermodynamic equilibrium is achieved at the film surfaces. The permeating may then be defined simply in terms of permeability coefficient, $P$, diffusion coefficient, $D$, and solubility, $S$, of the permeant in the polymer:

$$
\bar{P}-D \cdot S
$$

This equation is a fundamental modeling equation for permeation in polymers. It relates the practical barrier coefficient of flux, $P(-Q)$, to the phaseboundary equilibrium constant, $S$, and the mass transfer coefficient within the polymer, D (Sweeting 1971).

Membrane separation processes using synthetic polymer films are being established in ever increasing areas of the chemical and petroleum process industries, as well as in the biomedical field. Some areas that have received a good deal of development are water desalination by reverse osmosis (Podall 1972), helium separation from natural gas (Rogers, Fels and Li 1972; Pan and Habgood 1978a; 1978b), purification steps using cellulose acetate hollow fibers, and in the medical field--artificial kidneys (Kesting 1971) and blood oxygenators (artificial lungs) (Skiens et al. 1971; Zapole and Ketteringham 1975). In desalinating water by reverse osmosis, it has been possible with appropriate membrane modification to increase the water permeability of selective membranes by more than 1000 times without reducing the water and salt separation factors.

One of the major advantages of these process industry separation techniques is the generally low amount of energy required to achieve the desired separations. For example, in desalination where low-cost water is desired, the membrane process is one of the few that does not require a phase change with the consequent energy input. With suitably designed membrane systems, it is possible to take advantage of both high pressures and higher temperatures, both of which may be expected to be of benefit in the types of gas separations of concern in this study. 
PROPOSED PROCESS

Researchers in Japan have recently reported that polyoximine polymers synthesized from polyketones will readily bind Group VIII metals (Fe, $\mathrm{Ni}, \mathrm{Co}$ ) which in turn readily form carbon monoxide complexes (Kim and Takizawa 1974a; 1974b; 1975). These polymeric materials consequently show a high selectvity for carbon monoxide over most other gases found in waste gas streams. The binding of carbon monoxide by these complexes is generally reversible, and thus, a relatively high pressure or concentration of carbon monoxide on one side of a suitably selective membrane will permit the permeation through and withdrawal of carbon monoxide on the low pressure (concentration) side of the membrane. Since the permeability of the gas through a membrane is directly proportional to its solubility in the membrane (see Equation (4)), it should be possible with these materials to separate a relatively pure carbon monoxide stream from a dilute waste gas product. It should also be possible to increase the driving force for the separation by increasing the pressure on the waste stream side of the membrane and/or lowering the pressure on the downstream side. Temperature also can be expected to effect solubility and diffusion rates through membranes. This separation can be especially well accomplished by using fine hollow-fiber membranes which, in addition to providing high surface areas per unit volume, can operate at high pressures (500 to 1000 psi) without back-up plates, which would be required if flat film separation equipment were used (Gardiner, Crane and Hannan 1977; Antonson et al. 1977). The initial work in preparing and evaluating the permselective membranes, however, whould use flat films because of the ease of handling films in laboratory studies. The membranes studied could be formed directly from the polyoxime metal complexes, or a thin layer of the complex could be coated on porous polymeric substrates, as is frequently done in other membrane separation techniques (Yasuda and Marsh 1975).

Literature surveys indicate that most transition metal complexes, such as those described above, generally selectively bind both carbon monoxide and oxygen $\left(\mathrm{O}_{2}\right)$ over most other components in waste gas streams, e.g., nitrogen, carbon dioxide, sulfur dioxide, argon, water vapor, etc. However, usually the binding of carbon monoxide and oxygen molecules is significantly different such 
that these two gases can also be separated by selecting the complexing system. With a copper complex system, oxygen binding is of ten favored over carbon monoxide, while in iron complexes carbon monoxide is frequently much more strongly complexed than oxygen.

\section{MEMBRANE PREPARATION AND EVALUATION}

The first step in preparing selective membranes for evaluation was to prepare or obtain polymeric materials that might be further reacted or processed to form a complexing membrane or film. The membrane could then be tested with a suitably designed gas-membrane separation system with a mixture of gases containing carbon monoxide.

Polymer and Complex Preparation

Polymeric metal chelate complexes were prepared using a method developed by Kim and Takizawa (1974b). A carbon monoxide-ethylene copolymer was used to form the backbone of the polymer complex. Ethylene and carbon monoxide were polymerized under pressure using 2,2'azobisisobutyronitrile as an initiator. Mole ratios of the two monomers were varied, as well as the total system pressure, for the purpose of producing higher molecular weight polyketones of greater carbon monoxide content. This preparation technique was intended to avoid the brittleness of low molecule weight polymers produced at lower pressures. Low molecular weight polymers could not be formed into acceptable membranes by either solution casting or melt pressing. Unfortunately, we were unable to obtain polymers with molecular weights greater than 10,000, which was very marginal for our experimental purposes.

The polyketone backbone was converted to a polyoxime by C-nitrosation of the active methylene groups and by oximation of the carbonyl groups. C-nitrosation was carried out by addition of butyl nitrite to a solution of the polyketone in chloroform together with anhydrous hydrogen chloride. Careful exclusion of moisture was found to be essential in this step. oximation of the carbonyl groups was carried out by addition of hydroxylamine to a solution of the polymer in dioxane/isopropanol. Dissolution of the polymer in this solvent prior to reaction proved to be difficult, especially as the molecular weight of 
the polymer increased. Polyoxime-metal chelate complexes were prepared by addition of divalent metal salts. The most useful complex was prepared by addition of ferrous ion. Careful exclusion of atmospheric oxygen and an acidic medium were required to prevent oxidation of ferrous ion prior to formation of the complex. The insoluble complexes that were formed in this manner were washed and dried in a vacuum oven before attempting to form them into membranes for testing.

\section{Membrane Testing Equipment}

Although, for a number of reasons, the final desired form of a separation membrane is a fine hollow fiber, for ease of preparation and initial testing it is best to prepare materials as a flat film. The initial apparatus, therefore, took the form of a film testing device. The membrane holder (shown in Figure 11) consisted of a cell whose base was made from a blind flange. A hole was drilled through the flange center to permit any permeant gas to flow through this hole for a volume measurement and analysis. On the inside of the flange and covering the hole, a porous fine metal frit ( 1/8 in. thick) was counter-sunk into the flange such that the frit's surface was flush with that of the flange. The frit was press fit into the countersunk hole. The purpose of the frit was to support the polymer membrane over the hole in the flange and prevent rupture of the membrane at high pressure. The top of the cell consisted of another blind flange of equal size with an 0 -ring groove machined into it such that the 0-ring pressed on the membrane that rested on the lower blind flange to create the high pressure seal for the cell. The top also had two holes to permit gas influent and effluent flow in the cell. One or two pieces of porous paper ( $f i l$ ter paper) were placed under the polymer membrane to permit gas permeating any portion of the active polymer membrane surface to then flow through the porous paper to the frit and thence from the cell. The two blind flanges comprising the cell were bolted together during operation of the permeation system.

The total apparatus, including the cell just described, is shown in Figure 12. The set-up consisted of a high-pressure cylinder containing an approximately 50/50 mixture of carbon monoxide and nitrogen. A pressurereducing valve on the cylinder was connected by a 1/8-in. stainless steel tube 


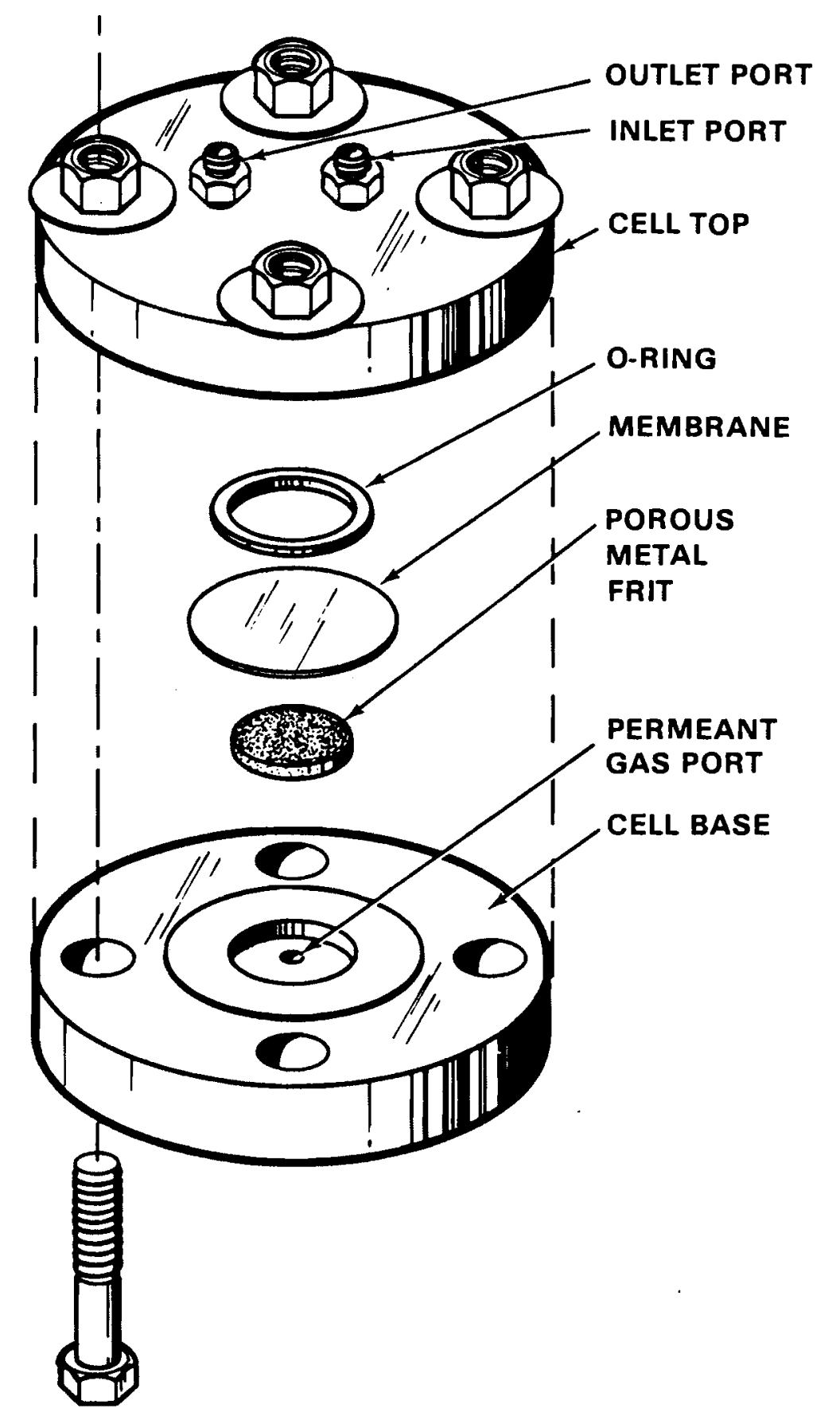

FIGURE 11. Gas Selective Permeation Cell

to the inlet port in the top of the permeation cell. The outlet port in the cell was connected by similar tubing to a S.S. micrometer actuated needle valve which was used to control the flow of gas through the top of the cell. The need le valve was further connected to a calibrated gas flowmeter so the volume 


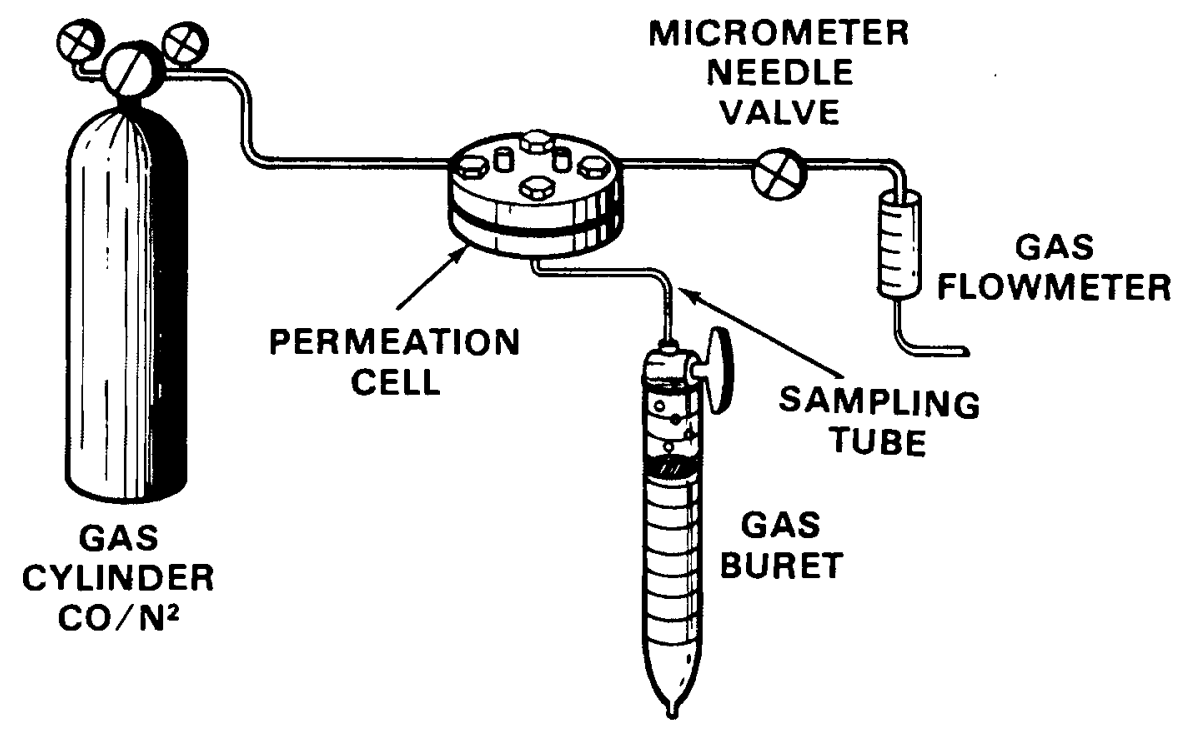

FIGURE 12. Permselective Membrane Apparatus for Gas Separation and Measurement

of gas passing through the cell above the membrane could be determined and controlled. The port in the bottom half of the cell under the membrane was connected by tubing to a gas buret for permeant volume measurements. A portion of the line was gum rubber tubing so that a gas sampling syringe needle could be passed through the tubing wall to collect samples for analysis. The entire apparatus with the exception of the gas cylinder was housed in a fume hood.

Samples taken in the gas syringe were injected into a Hewlett Packard $7620 \mathrm{~A}$ gas chromatograph and the $\mathrm{CO} / \mathrm{N}_{2}$ concentration was determined using a 5 A molecular sieve column.

Membrane Preparation

After the initial polymerization of carbon monoxide and ethylene to form polyketone copolymers and the subsequent reaction to form polyoximes, flat film was fabricated for testing as membranes both before and after the attempted formation of metal complexes. In general, the molecular weight of the carbon monoxide/ethylene copolymers was low [less than 20,000 by gel permeation chromatography (GPC)], and the metal complexes prepared from the polyoximes of these copolymers were insoluble in organic solvents and could not melt without decomposition of the oxime. The materials alsó tended to be brittle and could 
not be expected to form usable membranes by themselves. Both the polyketones and the polyoximes prepared from them are soluble in organic systems; and it was felt that to prepare a usable membrane, a film of the polyoxime must first be formed by casting from a suitable solvent system (e.g., dioxane/methanol), followed by complex formation between the film and a metal salt (iron) solution.

Since suitable, non-brittle, complex membranes were not available from the carbon monoxide/ethylene copolymers, it was decided to mix an iron polymer complex powder, prepared as described earlier, with a silicone RTV material to form a flexible film that might have a degree of selectivity for carbon monoxide. Of all known polymers, silicone materials have the highest permeability to permanent gases. The iron polymer complexes were mixed with liquid 382 Silastic ${ }^{\circledR}$ RTV, the catalyst was added, the mixture was degassed, and a thin film was cast and allowed to cure overnight. A suitably sized membrane disc was then cut from the polymerized material and placed in the permeation apparatus for evaluation.

Another type of membrane was prepared from a commercial polyvinylpyrrolidone (K-90) polymer available in our laboratory. This material, with a molecular weight of about 360,000, was dissolved at a $10 \%$ level in water and to this was added a $10 \%$ solution of ferric chloride to form a PVP-iron complex. Films were cast and tested in the permeation cell.

\section{RESULTS}

The study showed that polymeric material could be prepared readily from mixtures of carbon monoxide and ethylene gases in an autoclave following the type of procedure outlined by Nozaki (1974) or Kim and Takizawa (1974b). However, the polymers prepared by these techniques were of low molecular weight $(<10,000)$ and apparently of lower carbon monoxide (carbonyl) content than would be desired (neutron magnetic resonance (NMR) indicated a ratio of only about one carbonyl per five ethylene groups). Although these polyketones were

(B) Silastic is a registered trademark of Dow Corning Corporation, Midland, Michigan. 
further reacted to convert them to polyoximes, the resultant materials were apparently of a molecular weight too low to form intact films. The iron polyoxime complex material was mixed as a power $(-25 \%)$ with a silicone rubber base, a film was cast from the viscous polymer mix, and the film was cured. A piece of this material tested in the membrane permeation cell using a $49 \% \mathrm{CO}, 51 \% \mathrm{~N}_{2}$ gas stream gave a total gas permeability of $5.0 \times 10^{6} \mathrm{cc} \mathrm{mm}\left(\mathrm{m}^{2}\right)^{-1} \mathrm{day}^{-1}$ at $\sim 500$ psi operating pressure, and a separation factor $(a)$ of about 1.15 to $1.20 \mathrm{CO} / \mathrm{N}_{2}$ was obtained in a single pass. This is to be compared with a silicone membrane made with the same silicone polymer but with no iron polyoxime complex added--7.5 $\times 20^{6} \mathrm{cc} \mathrm{mm}\left(\mathrm{m}^{2}\right)^{-1}$ day $^{-1}$ at $500 \mathrm{psi}$ in the cell. In this case, little or no separation between carbon monoxide and nitrogen was observed. Other silicone membranes containing lesser amounts (10\%) of the iron chelate polyoxime mixed with silicone rubber were also prepared and tested. A significantly lesser separation of carbon monoxide and nitrogen was generally obtained with these membranes at about the same gas permeation rate. (Where separation factors were less than 1.05 there is some question of the ir significance due to analytical variation.)

Samples of films prepared from solutions polyvinyl-pyrrolidone and iron salts were also tested in the permeation equipment. In general, these films (some films were plasticized with glycerin to make them more flexible) were of considerably lower permeability (factor of 10 less) than the silicone or silicone/iron polyoxime films and did not show significant separation factors for carbon monoxide (maximum of $5 \%$ enrichment) over nitrogen.

This type of gas separation or waste gas stream enrichment concept using selective membranes and especially ultimately utilizing fine hollow fiber separation modules continues to hold promise for a number of processes. Further work on the basic membrane properties and preparation is needed to produce a membrane of high permeability to carbon monoxide and enhanced selectivity for carbon monoxide.

(a) Separation factor is $\left(\frac{\mathrm{CO} / \mathrm{N}_{2}}{\mathrm{CO} / \mathrm{N}_{2}}\right.$ - peed feed $)$ 


\section{REFERENCES}

American Iron and Steel Institute. 1980. Annual Statistical Report for 1979. Washington, DC.

American Iron and Stee 1 Institute. 1976. Handbook on Energy Conservation Technology in the Steel Industry. Washington, DC.

Antonson, C. R., et al. 1977. "Analys is of Gas Separation by Permeation in Hollow Fibers." Ind. Eng. Process Des. Dev. 16:463.

Barrer, R. 1939. Trans. Faraday Soc. 35:628.

Bassett, L. C., and R. S. Natarajan. 1980. "Hydrogen--Buy It or Make It." Chemical Engineering Progress 76(3):93-97.

Berry, R. I. 1980. "Hydrogen Route's Future is Keyed to Economics." Chemical Engineering $87(14): 80-84$.

Brandi, H. T., G. Heynert and E. Wilms. 1970. "Increase in Pig Iron Production and Reduction in Fuel Consumption as a Result of High Blast Temperature, Oxygen-Enrichment, 0il-Injection and High-Top Pressure." In Proceedings of International Conference on the Science and Technology of Iron and Steel, Part 1. ed. R. R. Kasigate, pp. 156-158. The Iron and Steel Institute of Japan, Tokyo.

Buck, B. O., and R. S. Leitch. 1958. "CO2 Removal From Natural Gas." The Oil and Gas Journal 56(38):99-104.

Crank, J., and C. S. Parks, eds. 1968. Diffusion in Polymers. Academic Press, New York.

Curtis, G. R. 1976. "Utilization of BOF Off-Gas." Prepared for the 84th General Meeting of the American Iron and Steel Institute, May 26-27, New York.

Daynes, H. A. 1920. Proc. Royal Soc. 97A:286.

Erickmeyer, A. G. 1958. "Costs Favor Hot Carbonate Process." Chemical Engineering 65(17):113-116.

Fallwe11, W., and B. Greek. 1980. "Key Chemicals--Hydrogen." Chemical and Engineering News 48(31):15.

Fujita, H. 1961. "Diffusion in Polymer-Diluent Systems." Fortschr. Hochpolym. Forsch 3:1.

Gardiner, R. J., R. A. Crane and J. F. Hannan. 1977. "Hollow Fiber Permeator for Separating Gases." CEP, October p. 76. 
Haase, D. J., and D. G. Walker. 1974. "The COSORB Process." Chemical Engineering 70(5):74-77.

Kesting, R. E. 1971. Synthetic Polymeric Membranes. McGraw-Hil1, Inc., New York.

Kim, S. J., and T. Takizawa. 1974a. "Reversible Uptake of Molecular $0_{2}$ and CO by a New Polyoxime-Copper Complex." J. C. S. Chem. Comm. 356.

Kim, S. J., and T. Takizawa. 1974b. "Preparation of a Novel Polyoxime and Reversible Uptakes of Molecular $\mathrm{O}_{2}$ and $\mathrm{CO}$ by its Metal Complexes." Makromol Chem. 175:125.

Kim, S. J., and T. Takizawa. 1975. "Activity of a new Polyoxime-Copper Complex in the Reversible Uptake of Molecular $\mathrm{O}_{2}$ and $\mathrm{CO} . "$ Makromol Chem. $176: 891$.

Lyke, S. E., and R. H. Moore. 1980. Methanol Production with Elemental Phosphorus Byproduct Gas: Technical and Economic Feasibility. PNL-3694, Pacific Northwest Laboratory, Richland, Washington.

McCandless, F. P. 1972. "Separation of Binary Mixtures of $\mathrm{CO}$ and $\mathrm{H}_{2}$ by Permeation Through Polymeric Films." Ind. Eng. Chem., Proc. Des. Develop. $11: 470$.

McGannon, H. E., ed. 1971. The Making, Shaping and Treating of Steel. 9th ed. United States Steel Corporation, Pittsburgh, Pennsylvania.

McHugh, M., III. 1980. "Hydrogen Distribution Safety." Paper \#13 of American Chemical Society Symposium Series \#116, p. 253.

Mullowney, J. F. 1957. "Which $\mathrm{CO}_{2}$ Removal Scheme is Best?" Petroleum Refiner $36(12): 149-152$.

Nozaki, K. 1974. U.S. Patent 3,835,123, U.S. Patent Office, Washington, D.C.

Pan, C. Y., and H. W. Habgood. 1978a. "Gas Separation by Permeation:

Part I." The Can. J. Chem. Eng. 56:197.

Pan, C. Y., and H.W. Habgood. 1978b. "Gas Separation by Permeation:

Part II. The Can. J. Chem. Eng. 56:210.

Paxton, H. W. 1977. "Feasibility Study of a Modern All-Coal Integrated Steel Plant." Presented at the Seventh C. C. Furnace Memorial Conference, June 21, 1977. Massachusetts Institute of Technology, Boston.

Poda11, H. E. 1972. "Reverse Osmosis" in Recent Developments in Separation Science, Vol. II, N. N. Li, ed. CRC Press, Cleveland, Ohio. 
Rogers, C. E., M. Fels and N. N. Li. 1972. "Separation by Permeation Through Polymeric Membranes" in Recent Developments in Separation Science, Vol. II,

N. N. Li, ed. CRC Press, CTeveland, Ohio.

Rohrmann, C. A., et al. 1977. Chemical Production from Carbon Monoxide - Its Potential for Energy Conservation. BNWL-2137, Pacific Northwest Laboratories, Richland, Washington.

Skiens, W. E., et al. 1971. "Hollow Fiber Membrane Oxygenator." J.Biomed. Mater. Res. Symp. 1:135.

Sweeting, 0. J., ed. 1971. The Science and Technology of Polymer Films, Vol. II. John Wiley and Sons, New York.

Union Carbide Corporation, Linde Division. 1975. "Hydrogen Purificaton." Hydrocarbon Processing 54(5).

Yasuda, H., and H. C. Marsh. 1975. "Preparation of Composite Reverse Osmosis Membranes by Plasma Polymerization of Organic Compounds." J. Appl. Polym. Sci. 19:2981.

Zapol, W. M., and J. Ketteringham. 1975. "Improved Biomaterials for Artificial Lung Membranes" in Polymers in Medicine and Surgery, R. L. Kronenthol, Z. Oser, and E. Martin, eds. Plenum Press, New York. 


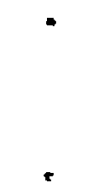


APPENDIX A

MARKET SURVEY UPDATE 


\section{MARKET SURVEY UPDATE}

Economic incentives for utilizing byproduct bases for chemical production can be of two types: capital cost savings and operating cost savings. The less tangible incentives such as natural gas conservation are adequately represented by the economic incentives and need not be addressed separately. Capital savings can result if the byproduct gas already has the composition required by the chemical process or requires less expensive equipment for processing to that composition than does the conventional feedstock. For example, reforming followed by cryogenic separation required to produce a hydrogen-free CO stream may be replaced by a simple clean-up operation if a byproduct $\mathrm{CO}$ stream is available. Operating cost savings can result from utilizing a byproduct gas if that gas is currently not utilized or can be replaced in its current use at a lower cost than the conventional feedstock it displaces. For example, a $\mathrm{CO} / \mathrm{H}_{2}$ containing off gas currently used as fuel may be replaced by coal and may displace natural gas feedstock on an approximately equivalent-energy basis. The cost per unit energy of coal is one-third that of natural gas, resulting in significant savings.

The savings depend upon the feedstock and energy requirements of a given chemical process and can only be judged in the contegt of the total costs involved in a chemical venture. Furthermore, success of such a venture depends upon favorable supplies and markets for all feeds and products involved. Market data, including feedstock consumption, prices and production statistics, are therefore required to evaluate the feasibility of any byproduct gas utilization project.

More than two years have elapsed since the report "Chemical Production from Waste Carbon Monoxide - Its Potential for Energy Conservation" by C. A. Rohrmann et al. (1977) was published. This present report serves to update and expand upon some of the market information presented in that report. Thirteen major industrial chemicals that can use carbon monoxide-based feedstocks are discussed; presented here are 1979 U. S. production, estimated West Coast consumption/production, recent new plant sizes, and current conventional feedstock and product price data. 
The thirteen chemicals studied are listed in Table A.1. Each will be discussed separately below. They include chemicals and some of their major derivatives, as illustrated in Figure A.1, for which commercial production is based, at least in part, on $\mathrm{CO}$ or synthesis gas, $\mathrm{CO}+\mathrm{H}_{2} \cdot \mathrm{H}_{2}$ can be produced from $\mathrm{CO}$ by the water-gas shift reaction. Feeds required by each chemical are indicated in parenthesis and, for derivatives, by arrows. The chemicals considered are generally those that could potentially use more than 100 million lb/yr of $\mathrm{CO}$ in the United States. Methyl tert-butyl ether (MtBE) was not included in the original report. From no U.S. production in 1977, it has grown to be one of the major derivatives of methanol in 1980. Acetic anhydride, included in the original report, is primarily an intermediate in the production of cellulose acetate, included here.

\section{AMMONIA}

Natural gas, liquid petroleum gas (LPG) or naptha is steam reformed followed by shift conversion, $\mathrm{CO}_{2}$ removal, methanation, and high-pressure synthes is to produce ammonia. Capital costs are high forcing the construction of large-scale plants in pursuit of economies of scale. Even a 1-billion-lb/yr plant would cost in the range of $\$ 85$ million (current dollars) or $8.5 \phi / 1 b / y r$ (Ricci 1979) indicating poor economics for a plant using the $\$ 3 / \mathrm{million}$ Btu natural gas costs assumed in Table A.1. Most U.S. producers are probably operating on lower cost gas. Since $\mathrm{CO}$ must be shifted to $\mathrm{H}_{2}$ for ammonia production, there is little prospect of capital savings through the use of industrial off gases, however, substantial savings in operating cost could result from lower energy costs for byproduct gas compared with natural gas feedstock. A very large source of off gas would be required such as from a major steel mill.

Major derivatives of ammonia are urea, nitric acid and ammonium phosphate with $80 \%$ of end uses in fertilizer (Fallwell and Greek 1980). Excess capacity exists in the U.S., and there has been no new construction announced for over a year. 1980 consumption is projected to exceed U.S. operating capacity, however, imports will more than take up the slack. Currently, any new plant would serve primarily to replace old, inefficient capacity. 
TABLE A.1. C0-Chemicals, Market Data Summary

\begin{tabular}{|c|c|c|c|c|c|c|c|}
\hline \multirow[b]{2}{*}{ Product } & \multirow{2}{*}{$\begin{array}{l}1979 \text { U.S. } \\
\text { Production, } \\
\text { Million lb/yr }\end{array}$} & \multirow{2}{*}{$\begin{array}{l}\quad \text { West } \\
\text { Consumption } \\
\text { /Production, } \\
\text { Million lb/yr }\end{array}$} & \multirow{2}{*}{$\begin{array}{l}\text { Typical New } \\
\text { Plant Size, } \\
\text { Million lb/yr }\end{array}$} & \multirow{2}{*}{$\begin{array}{l}\text { lb c0/lb Product } \\
\text { This Step } \\
\text { /Cumulative(a) } \\
\end{array}$} & \multirow{2}{*}{$\begin{array}{l}2 / 80 \\
\text { Price } \\
\mathrm{c} / \mathrm{lb}\end{array}$} & \multicolumn{2}{|c|}{ Conventional Feeds } \\
\hline & & & & & & Feedstock & Cost $c / l b$-product \\
\hline Ammonia & 35,000 & $? / \sim 3200$ & $700-1100$ & $3.6 / 3.6$ & 6 & $N G(b)$ & 4.7 \\
\hline Urea & 13,000 & $? / \sim 400$ & $200-1100$ & $2.5 / 2.5$ & $6.5-8.75$ & NG & 3.2 \\
\hline $\begin{array}{l}\text { Methanol } \\
\text { "Battelle Process" }\end{array}$ & 7,400 & $630 / 0$ & 950 & $\begin{array}{l}3.5 / 3.5 \\
0.5 / 0.5\end{array}$ & $\begin{array}{l}9.4 \\
9.4\end{array}$ & $\begin{array}{l}N G \\
N G\end{array}$ & $\begin{array}{l}4.6 \\
4.0\end{array}$ \\
\hline Formaldehyde, $37 \%$ & 6,500 & $\sim 1200 / \sim 1200$ & $50-250$ & $0 / 1.6$ & 7 & methanol & 4.2 \\
\hline Methyl tert-butyl ether & $1,460(c)$ & $4000(d) / 0$ & $200-600$ & $0 / 1.4$ & 17 & $\begin{array}{l}\text { methanol } \\
\text { isobutylene }\end{array}$ & $\begin{array}{l}3.9 \\
12 .(e)\end{array}$ \\
\hline Acetic Acid & 3,300 & $<5 / 0$ & $300-600$ & $0.5 / 2.4$ & 26 & $\begin{array}{c}\text { methanol } \\
\text { CO }\end{array}$ & $\begin{array}{l}5 \\
?\end{array}$ \\
\hline Vinyl Acetate & 2,000 & $\sim 125 / 0$ & $100-200$ & $0 / 1.8$ & 31 & $\begin{array}{l}\text { acetic acid } \\
\mathrm{C}_{2} \mathrm{H}_{4}\end{array}$ & $\begin{array}{r}19 \\
8\end{array}$ \\
\hline Cellulose Acetate & 740 & $<30 / 0$ & $?$ & $0 / 2.1$ & 88 & $\begin{array}{l}\text { cellulose } \\
\text { acetic acid }\end{array}$ & $\begin{array}{r}? \\
22\end{array}$ \\
\hline Acrylic Acid + Esters & 940 & $? / 0$ & $100-400$ & $0.2-0.4 / 0.4-1.3$ & $41-46$ & $\begin{array}{c}\text { acetylene } \\
\text { alcohols } \\
\text { CO }\end{array}$ & $\begin{array}{l}\text { (contract only) } \\
(\text { variable) } \\
?\end{array}$ \\
\hline Toluene di-isocyanate & 680 & $70(f) / 0$ & $50-100$ & $1.4 / 1.4$ & 74 & $\begin{array}{l}\text { dinitrotoluene } \\
\text { phosgene }\end{array}$ & $\begin{array}{l}36 \\
38 .(e)\end{array}$ \\
\hline $\begin{array}{l}\text { Methylene di-phenyl } \\
\text { isocyanate }\end{array}$ & 475 & $50(f) / 0$ & $25-150$ & $0.22 / 0.65$ & 76 & $\begin{array}{l}\text { aniline } \\
\text { phosgene } \\
\text { formaldehyde }\end{array}$ & $\begin{array}{l}31 \\
26 .(e)\end{array}$ \\
\hline N-Butanol & 730 & $? / 0$ & $100-300$ & $1.3 / 1.3$ & 29 & $\underset{N G}{\text { propylene }}$ & $\begin{array}{r}10 \\
2\end{array}$ \\
\hline 2-Ethylhexanol & 320 & neg/0 & $100-300$ & $1.5 / 1.5$ & 31 & $\begin{array}{c}\text { propylene } \\
\text { NG }\end{array}$ & $\begin{array}{r}12 \\
2\end{array}$ \\
\hline
\end{tabular}

(a) The first figure represents potential $c 0$ use in direct manufacture of product; the second represents potential cumulative CO use if other feedstocks are based on $\mathrm{CO}$.

(b) Natural gas, price: \$3/Million Btu

(c) 1980 capacity

(d) Possible demand, $10 \%$ of West Coast unleaded gas, 1980

(e) Market price, probably high
(f) Estimated as $10 \%$ of U.S. production 

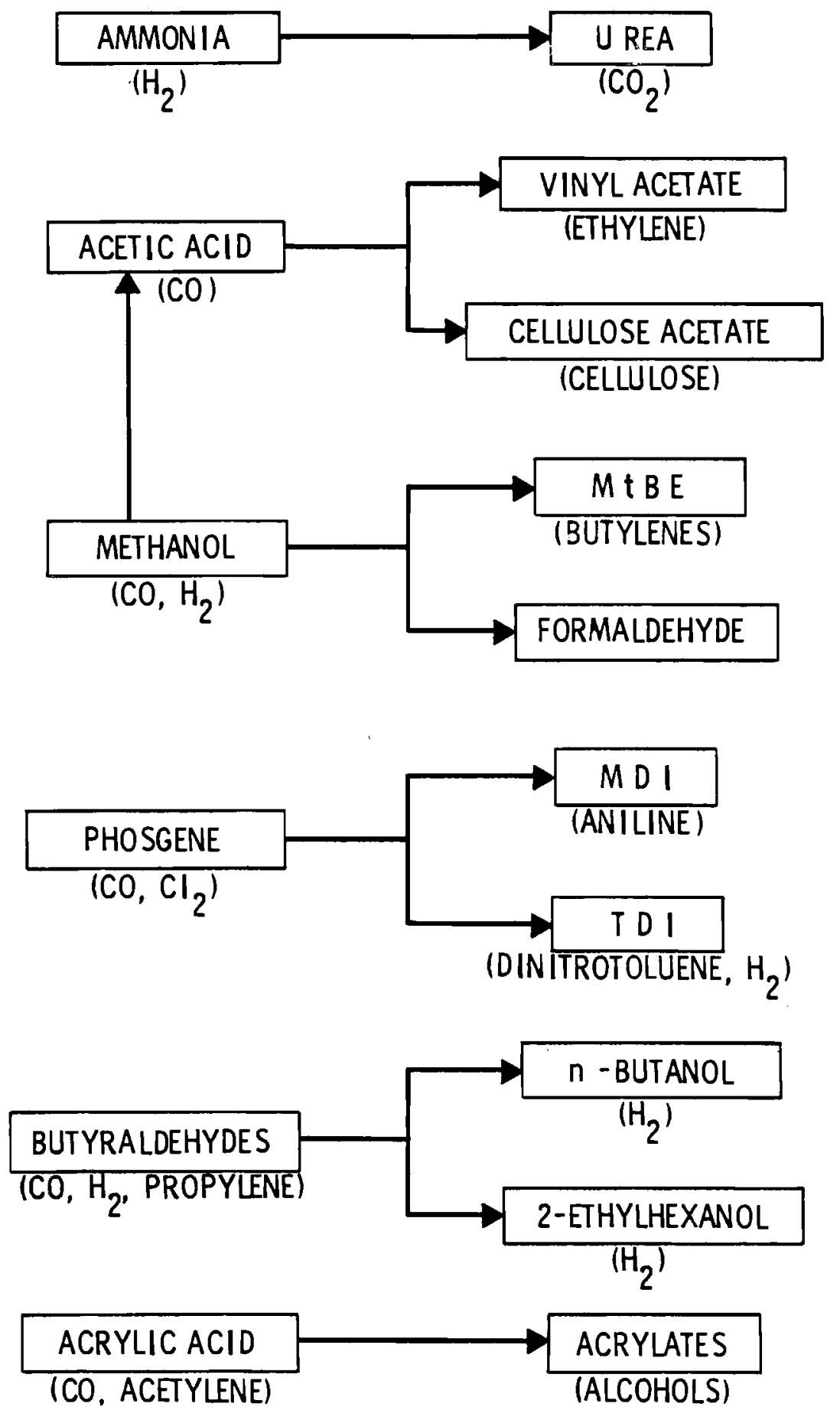

FIGURE A.1. Synthesis Gas Based Chemicals and Derivatives 
Data on ammonia use in the western United States have not been obtained. Although consumption may exceed capacity by enough to support a world-scale plant, no source of off gas of sufficient size has been located in the West.

UREA

Ammonia and carbon dioxide are reacted under pressure to form ammonium carbonate from which urea is produced by dehydration. Most urea plants are associated with ammonia plants which also provide the required $\mathrm{CO}_{2}$. Capital costs for this step are also high resulting in large capacities per stream. The excess $\mathrm{CO}_{2}$ available if $\mathrm{NH}_{3}$ is produced from $\mathrm{CO}$ is of no apparent advantage to conventional ammonia-urea routes. Two new ammonia processes have different $\mathrm{CO}_{2}$ removal schemes for which excess $\mathrm{CO}_{2}$ may show some advantage (Ricci 1979; Cronan 1979b). A new integrated ammonia-urea process (Lagana 1978), which allows savings over the two-step approach, shows less savings for a hydrogen-poor feedstock.

Fertilizer use accounts for $75 \%$ of production (Fallwell and Greek 1980) mostly as prills or urea-ammonium nitrate solutions. Smaller uses are ureaformaldehyde and urea-melamine resins and animal feed. Capacity and availability of low-cost $\mathrm{CO}_{2}$ are currently limiting urea production in the United States. No new capacity is under construction, apparently because urea can be more economically imported.

Western U.S. consumption probably exceeds production by enough to support a new plant. As with ammonia, however, a very large source of off gas would be required for a grass roots urea plant. A large source of byproduct $\mathrm{CO}_{2}$ might provide incentive for location of a urea plant that wodld import ammonia.

METHANOL

Synthesis gas from reforming of natural gas or other hydrocarbons is passed over a catalyst in a pressurized synthes is loop to form methanol. Methanol is removed from the loop by condensation, and a purge stream removes inerts such as methane. In the case of natural gas feed, the purge stream is 
large, removing excess hydrogen which provides most of the fuel for the reformer. Capital and fuel requirements are similar to ammonia production with large-capacity plants the rule.

A plant based entirely on $\mathrm{CO}$ would use shift conversion to reach the $2 / 1$, $\mathrm{H}_{2} / \mathrm{CO}$ ratio required for methanol synthesis. Although not as severe a conversion requirement as for ammonia, promise of capital savings over natural gas reforming is still small. If, however, a large enough source of off gas were available at a lower cost per unit energy than natural gas, operating savings could be substantial. Some capital savings can be obtained if co feed is used only to balance the synthesis gas from natural gas reforming, eliminating the need to purge hydrogen and reducing the size of the reformer. The column labeled "Battelle Process" in Table A.1 shows feed requirements from the preliminary basic design of a plant (see Appendix B) to produce methanol using $\mathrm{CO}$ for synthesis gas balancing plus $23 \%$ of the fuel requirement of the reformer. The figures in the fourth column of the table for cumulative co consumption per lb by methanol derivatives are based on methanol produced entirely from CO, that is, using 3.5 lb of $\mathrm{CO}$ per pound of methanol.

Major derivatives of methanol are formaldehyde, acetic acid and MtBE with . $60 \%$ of end use in polymer applications. Current fuel use of methanol is essentially limited to production of MtBE which is expected to reach $10 \%$ of U.S. consumption in 1980. Various large-scale fuel uses may develop within the decade greatly expending the industry (Burke 1979; Meisel et al. 1976;

Jonchere 1976). The first commercial venture using Mobil's methanol-to-gasoline process has just been announced (Deutsch 1980). New construction has been announced, however, that would double North American methanol capacity in 5 years and would provide for the most probable growth rate of demand through 1990 (Weismantel 1980).

Western U.S. methanol consumption is nearly large enough to support a world-scale plant, and demand could easily grow to that size in the 1980's. A new plant could displace methanol shipped from outside the region since methanol is currently produced in the west. Prospects for major derivatives are discussed in the following sections of this Appendix. 
FORMALDEHYDE

Methanol is catalytically oxidized at ordinary pressures to produce formaldehyde. Capital costs are relatively low allowing economical operation of small-scale plants. Since methanol cost takes $60 \%$ of the market price (see Table A.1), lower-cost methanol would have considerable effect on formaldehyde cost.

Major derivatives of formaldehyde (Fallwell and Greek 1980) are ureaformaldehyde, phenolformaldehyde and polyacetal resins, butanediol, and pentaerythrinol. End use is $60 \%$ in adhesives and $10 \%$ in plastics. Generally, formaldehyde cost represents a relatively small fraction of end product cost. The major adhesive use is in particle board and plywood manufacture which is tied to the housing industry. Since methanol can be shipped more economically than the $37 \%$ commercial formaldehyde solution, plants are scattered throughout the lumber-producing regions of the United States. Capacity use is traditionally low with little overall growth projected, although new capacity is under construction in several locations (Cronan 1979a).

The formaldehyde industry in the western United States is almost completely associated with the forest products industry and accounts for nearly all the 630-million-lb/yr estimated methanol consumption in Table A.1. It should provide a stable market for methanol. All of the new formaldehyde construction is in the east.

METHYL TERT-BUTYL ETHER (MtBE)

Methanol is reacted with isobutylene at moderate temperatures and pressure over an ion exchange catalyst to make MtBE. I sobutylene can be removed at good conversions from feed concentrations as $10 \mathrm{w}$ as the $10 \%$ to $15 \%$ found in $\mathrm{C}_{4}$ streams from catalytic crackers (Davis and Kohn 1979) although most current projects are based on olefin-plant $C_{4}$ streams in which the isobutylene concentration reaches $50 \%$, downstream of butadiene extraction. Capital costs are low, compared with methanol and ammonia plants, but they increase rapidly with feedstock dilution. Depending upon conditions at a given refinery, units as small as 30 million $1 b / y r$ can be justified. Cost of the isobutylene feed 
is difficult to calculate but methanol probably accounts for $35 \%$ to $50 \%$ of the feedstock cost which in turn is most of the cost of manufacture.

The only large-scale use of MtBE is as a high-octane blending component for unleaded gasoline where it can be used at concentrations up to 15\%. This results in a potential market far exceeding the available supplies of both methanol and isobutylene. Sun $0 i 1$ Company has proposed the possibility of producing MtBE based entirely on coal feed as well as directly from natural gas (for methanol) and mixed butanes via catalytic dehydrogenation (for iosbutylene) (Reynolds et a1. 1974); they are currently licensing conventionalfeed MtBE technology with no plans for construction (Davis and Kohn 1979). Growth of MtBE is expected to be limited by the availability of olefin plant $\mathrm{C}_{4}$ streams in the near future with some use of catalytic cracker streams at refineries where economics for the process are particularly attractive.

Catalytic crackers are the only significant source of isobutylene in the western United States. Catalytic crackers in California and Washington currently process 600,000 BPSD of fresh feed (Cantrel1 1979). Assuming that 2.4 Ib of isobutylene is produced per barrel of feed (industry estimate) and that $50 \%$ of that can be economically processed to MtBE, western production of MtBE could reach 360 million $1 \mathrm{~b} / \mathrm{yr}$ which would use $150 \mathrm{milli}$ ion lb/yr of methanol.

\section{ACETIC ACID}

Three commercial routes exist to acetic acid. Oxidation of acetaldehyde, which is largely ethylene based, oxidation of butanes, and reaction of methanol with carbon monoxide (carbonylation) have all seen recent industrial use but virtually all new construction is based on the third route. Two commerical processes exist for methanol carbonylation, the Reppe process, which uses C0 pressures of 7500 psi or more at $250^{\circ} \mathrm{C}$, and a new process developed by Monsanto, which can operate at atmospheric pressures and lower temperatures (Grove 1972). Both use liquid-phase reactors, but the Rh-I catalyst of 
Monsanto's process gives higher selectivity and yields on both reactants than the Reppe Co-I catalyst system. Although the presence of hydrogen does not lead to side reactions in the Monsanto process as it does in the Reppe, vent losses would increase with any diluent (Roth 1971). Since no hydrogen is required, substantial capital as well as operating cost savings could result for a plant using a relatively concentrated source of byproduct $C O$ compared with a plant using $\mathrm{CO}$ obtained by hydrocarbon reforming.

Although capital cost information is not available for methanol carbonylation, it is apparent that the Monsanto acetic acid process should involve considerably lower investment per unit product than ammonia or methanol production. Especially if a CO source is already available, it would seem that smaller plants may be more feasible than the two 600-million-1b/yr plants recently built in the United States or perhaps than Monsanto's pioneer 300-million-1b/yr plant (now expanded to 400 million).

Major derivatives of acetic acid are vinyl acetate, cellulose acetate and acetic esters (Kavaler 1978b; 1979a; 1977a). It is also used as a solvent in terepthalic acid and dimethyl terepthalate manufacture and in textile processing operations such as wool dyeing. Most aetic acid finds its end use in synthetic fibers and resins. Due to recent additions, current capacity is more than adequate; however, U.S. demand is growing steadily and should require new capacity by the mid 1980's. Phasing out of ethylene based capacity could hasten the need for new construction.

No acetic acid is produced in the western United States and consumption is small. One known use is for dyeing by the northwest wool industry. A possible outlet for acetic acid might result from the demand for vinyl acetate in the west as will be discussed further in this Appendix.

Vinyl Acetate

Acetic acid can be reacted with acetylene or with ethylene and oxygen to yield vinyl acetate. Due to the high energy costs of acetylene manufacture, the ethylene route is preferred for new plants in spite of somewhat lower yields. Capital costs is substantial. In early 1978 Celanese announced plans for a 100-million-lb/yr plant to be located in Alberta, Canada at a cost of 
$\$ 20 \mathrm{million}$ or $20 t / 1 \mathrm{~b} / \mathrm{yr}$ (Vervalin 1978). Recent U.S. capacity additions have been in 200-million-1b/yr increments (Cronan 1979a); 400-million-1b/yr plants have been built. Cost of acetic acid feed for vinyl acetate would be 19 $k / 1 \mathrm{~b}$ at current prices; therefore, CO availability could still impact the economics.

Major derivatives of vinyl acetate are polyvinyl acetate and polyvinyl alcohol. End use is almost exclusively in polymeric resins and adhesives. Exports in 1978 were 20\% of U.S. production (Kavaler 1978b). Capacity use is projected to approach $95 \%$ by 1982 or earlier if older acetylene-based units are shut down.

The western U.S. consumption figure in Table A.l is a rough estimate. Polyvinyl acetate emulsions and resins production seems to be fairly evenly distributed over the United States and took $47 \%$ of vinyl acetate production in 1978 (Kavler 1978b). A 150-million-1b/yr plant would use about 60 million $1 \mathrm{~b} / \mathrm{yr}$ of ethylene which would require a new supply in the west. Two options that might be economically feasible would be cryogenic tank car delivery, from Texas or from a new ethylene unit planned in Alberta, or recovery, from a western refinery off gas via a process such as Cosorb (Schultz et al. 1976). Cellulose Acetate

Acetic anhydride is produced by high-temperature, low-pressure conversion of acetic acid through ketene. Reaction of acetic anhydride with sulfuric acid-treated cellulose in acetic acid solution yields cellulose acetate and acetic acid for recycle. In 1979, 90\% of the acetic anhydride produced in the United States was used in cellulose acetate manufacture (Kavaler 1978a). The overall process of cellulose acetate manufacture is complicated and expensive. There has been no recent construction and the scale-related economics are not easily estimated. As can be seen in Table A.1, acetic acid cost represents only $25 \%$ of the product price. CO availability would, therefore, be expected to have somewhat less impact on cellulose acetate than on most of the chemicals discussed above.

Plans for a unique, new route to cellulose acetate have been announced by Tennessee Eastman (Schultz et al. 1980). Methanol will be produced via coal 
gasification and reacted with recycle acetic acid to make methyl acetate. Carbon monoxide, separated from the coal synthesis gas, will be reacted with the methyl acetate to make acetic anhydride for cellulose acetate manufacture. Apparently, the route would consume methanol and $\mathrm{CO}$ at the same rate as the conventional route using acetic acid from carbonylation of methanol, except that any lower yield of acetate from anhydride than the theoretical 50\% (based on acetyl groups) would have to result in excess production of acetic acid or anhydride. Since this route is already based on coal feedstock, the primary potential savings from byproduct $C O$ utilization would be capital savings through elimination of $\mathrm{CO}$ separation equipment and reduction in required coal gasification capacity.

The major uses of cellulose acetate are for yarn, cigarette filter tow, and plastics including photographic film. Demand is projected to remain nearly flat due to a declining market for cellulose acetate yarn (Kavaler 1979a). No cellulose acetate is produced in the western United States where the only market that may exist would be for use in plastics.

ACRYLIC ACID AND ESTERS

Carbon monoxide can be reacted with acetylene and water or an alcohol via the Reppe reaction to make acrylic acid or the corresponding acrylate. The data in Table A.l for $\mathrm{CO}$ use and feedstocks are based on that route. Because of the higher energy costs of acetylene manufacture, however, that process has been largely replaced by the propylene-based route, which does not use $C O$ (Kavaler 1979b). Acrylates production, therefore, is no longer a potential consumer of byproduct $\mathrm{CO}$.

TOLUENE DI-ISOCYANATES (TDI)

Phosgene is produced by reaction of $\mathrm{CO}$ and chlorine over an activated carbon catalyst. In $1979,86 \%$ of U.S. phosgene production was used in the manufacture of TDI or of methylene di-phenyl isocyanate (MDI) which will be discussed in the next section (Kavaler 1979b; 1979c). 
Toluene diamine (mixed isomers) produced by hydrogen reduction of dinitro toluene, is reacted with phosgene in a three stage reactor to make TDI and byproduct HCL. Judging from small plant sizes and the small margin between market prices of the product and its required feedstocks (Table A.1), scale-related capital costs are apparently not an overriding factor. The CO utilization figure given in the table includes $\mathrm{CO}$ for shift conversion to the $\mathrm{H}_{2}$ required for reduction of dinitro toluene ( 1 lb CO/lb TDI), as well as the relatively pure $C 0$ required for phosgene manufacture $(0.4 \mathrm{lb}$ CO/Ib TDI ). The latter represents a relatively high value use for byproduct $\mathrm{CO}$ although the probable savings would be less than $5 \%$ of product price.

TDI is used primarily in manufacture of flexible polyurethane foams. Current capacity use in the industry is high largely due to export demand (Kavaler 1979b). Modest growth of U.S. demand is forecast.

Polyurethane foam is manufactured in the western United States using TDI produced in the east. Sufficient demand probably exists to support a plant. Besides $\mathrm{CO}$, however, sources of the toluene, nitric acid, and chlorine required for TDI manufacture would have to be located, as would a market for byproduct $\mathrm{HCl}$.

METHYLENE DI-PHENYL ISOCYANATE (MDI)

Aniline is reacted with formaldehyde to produce diamino-diphenyl-methane. Reaction of that amine with phosgene, as in TDI manufacture, produces MDI and byproduct $\mathrm{HCl}$. It is noteworthy that a larger gap is apparent in Table A.l between product price and feedstock costs for MDI rather than the un-reduced nitrate (dinitrotoluene) as for TDI. The use of market prices for intermediates, however, may not be a reliable base for conclusions about manufacturing costs.

The CO use figure in the table for "This Step" includes only co for the phosgene required to make MDI. The "cumulative" figure includes phosgene CO plus that which would be used if the formaldehyde feed was also co based. The high-value (phosgene) CO used for MDI is a smaller fraction of product weight than for TDI with cost savings likely to be less than $3 \%$ of MDI's price. 
The major use of MDI is in manufacture of rigid polyurethane foam, used in the booming insulation industry. Several new markets for MDI are also developing and growth rates of $8 \% / y r$ are forecast (Kavaler 1979c). Supply is currently tight, but sufficient capacity is under construction to meet demand into the mid 1980 's.

MDI is consumed in the western United States, but, as with TDI, further research would be required to determine if a plant would be feasible. Required feeds would be $\mathrm{CO}, \mathrm{CO}_{2}$, aniline (or benzene, $\mathrm{HNO}_{3}$ and more reducing gas) and formaldehyde. Byproduct $\mathrm{HCl}$ would again have to be marketed.

n-BUTANOL AND 2-ETHYL HEXANOL

Propylene and a synthesis gas composed of $\mathrm{CO}$ and $\mathrm{H}_{2}$ in a 1-to-1 ratio are reacted over a rhodium or cobalt-based catalyst at moderate or high pressure to yield n-butyraldehyde and isobutyraldehyde (the "oxo" reaction). $n$-Butyraldehyde, the desired product, is further hydrogenated to yield n-butanol or converted via aldol condensation, dehydration and hydrogenation to 2-ethyl hexano1. Isobutyraldehyde produced in $10 \%$ yield or less over the rhodium catalyst and $20 \%$ to $25 \%$ yield over cobalt, is hydrogenated to isobutanol (Cronan 1977). The oxo reaction is used in the commercial synthes is of higher alcohols and other chemicals but not in large enough quantities to be a significant use for byproduct $\mathrm{CO}$.

Shift conversion would be needed to produce the required synthes is gas from a source of byproduct $\mathrm{CO}$. The $\mathrm{CO}$ requirements relative to product prices (Table A.1), however, show somewhat greater potential for significant impact of byproduct CO availability on production costs than in the case of isocyanates. Capital costs are probably significant but plant size may be limited by market considerations.

$n$-Butanol is used as a solvent and as a feedstock for butyl acrylate, glycol ethers and plasticizers (Kavaler 1978c). Seventeen percent of 1978 U.S. production was exported. Plasticizers, primarily dioctylphthalate, consume most 2-ethylhexanol production with 2-ethylhexyl acrylate the only 
other major derivative. Adequate capacity exists for both chemicals in the United States and moderate growth is predicted Demand in the western United States alone is probably not adequate to justify a new plant, although existence of an export market indicates that a plant might be considered wherever a favorable feedstock position seems likely. 
MARKET SURVEY CONCLUSIONS

- Significant potential impact on production economics of byproduct gas utilization can occur in two ways which seem to operate on separate groups of chemicals. Operating cost savings, resulting when the byproduct gas is less expensive than the natural gas it replaces, have greatest potential impact on large-volume, low unit price chemicals where the cost of natural gas feedstock represents a large fraction of product price. Chemicals, for which capital cost savings (primarily from elimination of processing steps) seem likely to be most significant, tend to be lower-volume, higher unit price commodities.

- Most significant impact of operating cost savings from byproduct gas utilization is possible on the production economics of ammonia and methanol.

- Capital as well as operating cost savings from byproduct gas utilization seem most likely to impact production economics of acetic acid, the isocyanates and, if the Reppe-acetylene-based route were used, the acrylates.

- From a marketing standpoint alone, construction of a major new plant in the United States during the next five years (in addition to those already announced) may be feasible for any of the chemicals discussed with the possible exception of formaldehyde and cellulose acetate.

- From a market standpoint alone, construction of a new plant in the western United States in the next five years may be feasible for ammonia, methanol, TDI and MDI by displacing shipments from outside the region.

- Methanol production may grow dramatically in the next decade as rising fuel prices meet costs for new fuel-use technologies. 
- New plants utilizing byproduct gas feed in the western United States appear to be most attractive for methanol and its derivative MtBE, and for acetic acid, dependent for most of its western market on construction of a new vinyl acetate plant.

- Less likely candidates are $n$-butanol and 2-ethylhexanol because of limited markets, and acrylates because of the phasing out of the Reppe process. 
MARKET SURVEY REFERENCES

Burke, D. P. 1975. "Methanol." Chemical Week 117(3):33-42.

Cantrel1, A. 1979. "Annual Refining Survey." The $0 i 1$ and Gas Journal $77(13): 122-155$.

Cronan, C. S. 1977. "Low-Pressure 0xo Process Yields a Better Product Mix." Chemical Engineering 84(26):110-115.

Cronan, C.S., ed. 1979a. "New Plants and Facilities...CE Construction Alert." Chemical Engineering 86(23):131.

Cronan, C. S., ed. 1979b. "Improved Ammonia Process." Chemical Enginering $86(26): 88-89$.

Davis, J.C., and P. M. Kohn. 1979. "MtBE Bandwagon." Chemical Engineering 86(11):91.

Deutsch, D. J. 1980. "A Big Boost for Gasol ine-from-Methanol." Chemical Engineering 87(7):43-45.

Fallwell, W., and B. Greek. 1980. "Key Chemicals, Ammonia, Urea, Methanol, Formaldehyde." Chemical and Engineering News 58(4):13-16.

Grove, H. D. 1972. "Lowest Cost Acetic Acid via Methanol." Hydrocarbon Processing, 51(11):76-78.

Jonchere, J. P. 1976. "Methanol Seen as Hydrogen Source." The 0 il and Gas Journal $74(23): 71-73$.

Kavaler, A. B., ed. 1977a. "Acetic Acid." Chemical Marketing Reporter $211(14)$.

Kavaler, A. B., ed. 1977b. "Acrylates." Chemical Marketing Reporter $211(15)$.

Kavaler, A. B., ed. 1978a. "Acetic Anhydride." Chemical Marketing Reporter $213(11)$.

Kavaler, A. B., ed. 1978b. "Vinyl Acetate." Chemical Marketing Reporter $214(41)$.

Kavaler, A. B., ed. 1978c. "n-Butano1." Chemical Marketing Reporter $214(43)$.

Kavaler, A. B., ed. 1979a. "Cellulose Acetate." Chemical Marketing Reporter 216(44). 
Kavaler, A. B., ed. 1979b. "TDI." Chemical Marketing Reporter $216(46)$.

Kavaler, A. B., ed. 1979c. "MDI." Chemical Marketing Reporter 216(47).

Lagana, V. 1978. "Streamlined Process Trims Operating, Capital Costs," Chemical Engineering 85(1):37-39.

Meisel, S. L. et al. 1976. "Gasoline from Methanol in One Step." Chemtech $6(2): 86-89$.

Reynolds, R. W., et al. 1974. "Methyl Ethers as Motor Fuel Components," Symposium on the Role of Technology in the Energy Crisis, Division of Petroleum Chemistry, Inc., American Chemical Society, Atlantic City, New Jersey.

Ricci, L. J. 1979. "Tightening the Loop in Ammonia Manufacture." Chemical Engineering 86(3):54-55.

Rohrmann, C. A., et al. 1977. Chemical Production from Waste Carbon Monoxide - Its Potential for Energy Conservation, BNWL-2137, Batte17e, Pacific Northwest Laboratories, Richland, Washington.

Roth, J. F. et al. 1971. "Low Pressure Process for Acetic Acid via Carbonylation of Methanol." Chemtech 1(10):21.

Schultz, R. R., et al. 1976. "New Solvent Has Big Appetite," Chemical Week $119(24): 31$.

Schultz, R. R., et al. 1980. "A Giant Step: Acetic Anhydride Made From Coal." Chemical Week 126(3):40.

Vervalin, C. H., ed. 1978. "World-Wide Construction Boxscore." Hydrocarbon Processing 57(2):21.

Weismantel, G. E. 1980. "Methanol Supplies: Too Much or Too Little?" Chemical Engineering 87(14):75-78. 


\section{APPENDIX B}

CHARACTERIZATION OF A TYPICAL ELEMENTAL PHOSPHORUS BYPRODUCT GAS 
Summary information was prepared by PNL as a basis for a methanol production feasibility study (Lyke and Moore 1980). The information is based on off-gas samples obtained from Monsanto's Soda Springs, Idaho phosphorus plant and analyzed by Battelle's Columbus Laboratories.

Tables B.1 through B.3 list the chemical composition of the noncondensible, volatile and particulate fractions, respectively, of the off gas. The volatile components (see Table B.2) were based on elemental analysis of material passing through a heated $\left(>120^{\circ} \mathrm{C}\right)$ filter and subsequently collected in a water-cooled condenser, ion exchange resin, and impinger solutions of a gas sampling train.

Basic data for a typical off-gas stream are provided in the following list of characteristics.

$\begin{array}{ll}\text { Gas Temperature } & 35^{\circ} \mathrm{C} \text { to } 70^{\circ} \mathrm{C} \\ \text { Pressure } & 1.0 \text { to } 1.4 \mathrm{~atm} \\ \text { Recoverable CO } & 10,000 \text { to } 70,000 \mathrm{lb} / \mathrm{h} \\ \text { Outstanding Characteristics } & \begin{array}{l}\text { Saturated with water and } \\ \text { phosphorus vapor }\end{array} \\ \text { Particulate Loading } & 13.1 \text { to } 20.8 \mathrm{mg} / \mathrm{m}^{3} \\ & (80 \% \text { below } 3 \mu \mathrm{size})\end{array}$


TABLE B.1. Composition of the Noncondensible Fraction of the Off-Gas Stream

\begin{tabular}{|c|c|c|c|c|}
\hline \multirow[b]{2}{*}{ Major Components } & \multicolumn{2}{|c|}{ Range } & \multicolumn{2}{|c|}{ Average } \\
\hline & $\begin{array}{c}\text { vol\%, } \\
\text { dry basis }\end{array}$ & $\begin{array}{c}\text { ppm, } \\
\text { dry basis }\end{array}$ & $\begin{array}{c}\text { vol\%, } \\
\text { dry basis }\end{array}$ & $\begin{array}{c}\text { ppm, } \\
\text { dry basis }\end{array}$ \\
\hline $\mathrm{CO}$ & 95.2 to 98.3 & -- & 95.5 & -- \\
\hline $\mathrm{N}_{2}$ & 1.5 to 4.0 & -- & 2.6 & -- \\
\hline $\mathrm{O}_{2}$ & 0.2 to 0.8 & -- & 0.5 & -- \\
\hline $\mathrm{H}_{2} \mathrm{O}$ & saturated & -- & -- & -- \\
\hline$p^{-}$ & saturated & -- & -- & -- \\
\hline $\mathrm{H}_{2}$ & 1.2 to 1.5 & -- & 1.33 & -- \\
\hline $\mathrm{CO}_{2}$ & 0.13 to 0.17 & - & 0.15 & -- \\
\hline
\end{tabular}

Minor Components

\begin{tabular}{|c|c|c|c|c|}
\hline $\mathrm{Ar}$ & -- & -- & -- & 60 \\
\hline $\cos$ & -- & 70 to 78 & -- & 74 \\
\hline $\mathrm{H}_{2} \mathrm{~S}$ & -- & 120 to 140 & -- & 130 \\
\hline $\mathrm{CS}_{2}$ & -- & -- & -- & 3 \\
\hline $\mathrm{CH}_{4}$ & -- & 27 to 110 & -- & 49 \\
\hline $\mathrm{C}_{6} \mathrm{H}_{6}$ & -- & -- & -- & 1 \\
\hline $\mathrm{PH}_{3}$ & -- & 183 to 600 & -- & 385 \\
\hline $\mathrm{HCN}$ & -- & 693 to 1100 & -- & 880 \\
\hline$H F+F$ (calculated as HF) & -- & 283 to 696 & -- & 555 \\
\hline $\mathrm{HCl}+\mathrm{Cl}_{2}$ (calculated as $\left.\mathrm{HCl}\right)$ & -- & 77 to 129 & -- & 103 \\
\hline $\mathrm{NH}_{3}$ & -- & 4 to 38 & -- & 14 \\
\hline
\end{tabular}


TABLE B.2. Elemental Analysis of the Volatile Fraction of the Off-Gas Stream

\begin{tabular}{|c|c|c|}
\hline Elements & Range, $\mu \mathrm{g} / \mathrm{m}^{3}$ & Average, $\mu \mathrm{g} / \mathrm{m}^{3}$ \\
\hline $\mathrm{Ag}$ & 21 to 91 & 61 \\
\hline $\mathrm{Al}$ & 2,300 to 130,000 & 64,000 \\
\hline \multirow{2}{*}{$\begin{array}{l}\text { As } \\
B^{(a)}\end{array}$} & 6.3 to 18 & 13 \\
\hline & 3,000 to 300,000 & 110,000 \\
\hline $\mathrm{Ba}$ & 0.5 to 15 & 4.4 \\
\hline $\mathrm{Be}$ & $<0.6$ to 1 & 0.25 \\
\hline $\mathrm{Ca}$ & 4,300 to 11,000 & 6,400 \\
\hline Co & 270 to 1,900 & 800 \\
\hline $\mathrm{Cr}$ & 28 to 11,000 & 3,700 \\
\hline Cs & $<1$ & \\
\hline $\mathrm{Cu}$ & 2 to 7 & 5.3 \\
\hline $\mathrm{Fe}$ & 1,500 to 39,000 & 13,000 \\
\hline $\mathrm{Ge}$ & 0 to 140 & 45 \\
\hline $\mathrm{Hg}$ & $<0.3$ to 0.9 & 0.2 \\
\hline k & 30,000 to 60,000 & 48,000 \\
\hline Li & 18 to 461 & 160 \\
\hline $\mathrm{Mg}$ & 8,300 to 11,000 & 9,600 \\
\hline Mn & 16 to 340 & 150 \\
\hline Mo & 1 to 5 & 1.5 \\
\hline $\mathrm{Na}$ & 13,000 to 17,000 & 14,000 \\
\hline $\mathrm{Ni}$ & 7 to 110,000 & 47,000 \\
\hline P & Proprietary data - & assume saturated \\
\hline $\mathrm{Pb}$ & 1 to 2 & 1.3 \\
\hline $\mathrm{Rb}$ & 1 to 15 & 4.5 \\
\hline$S$ & 1,200 to 6,400 & 3,900 \\
\hline $\mathrm{Se}$ & 640 to 1,600 & 1,100 \\
\hline $\mathrm{Si}^{(\mathrm{a})}$ & 9,800 to $3,800,000$ & $1,200,000$ \\
\hline Sn & 1 to 3 & 2 \\
\hline $\mathrm{Sr}$ & 76 to 310 & 210 \\
\hline $\mathrm{Ti}$ & 420 to 770 & 600 \\
\hline v & 0.5 to 25 & 12 \\
\hline Y & $<1$ & \\
\hline$Z n$ & 430 to 4,200 & 1,900 \\
\hline $2 r$ & 0 to 6,900 & 4,200 \\
\hline
\end{tabular}

(a) High $B$ and Si content may be due to fluoride attack on glassware 
TABLE B.3. Elemental Analysis of the Particulate Fraction of the Off-Gas Stream (a)

\begin{tabular}{|c|c|c|}
\hline Elements & Range, $\mu \mathrm{g} / \mathrm{m}^{3}$ & Average, $\mu \mathrm{g} / \mathrm{m}^{3}$ \\
\hline $\mathrm{Ag}$ & 0 to 23 & 7 \\
\hline$A]^{(b)}$ & 0 to 79 & 31 \\
\hline As & 0.18 to 0.75 & 0.46 \\
\hline B & 0 to 0.94 & 0.4 \\
\hline $\mathrm{Ba}$ & 0 to 13 & 3 \\
\hline $\mathrm{Cl}$ & 32 to 5 & 38 \\
\hline Co & 0 to 1 & 0.25 \\
\hline $\mathrm{Cr}$ & 0 to 0.85 & 0.21 \\
\hline$F$ & 87 to 253 & 160 \\
\hline $\mathrm{Fe}^{(\mathrm{b})}$ & 0 to 10 & 6 \\
\hline Ga & 0.02 to 0.56 & 0.16 \\
\hline$k$ & 5 to 323 & 94 \\
\hline La & 0.08 to 0.66 & 0.26 \\
\hline Li & 0.3 to 5 & 2 \\
\hline$M g(b)$ & 0 to 297 & 92 \\
\hline$M n$ & 0 to 0.47 & 0.12 \\
\hline $\mathrm{Na}(\mathrm{b})$ & 24 to 2480 & 740 \\
\hline $\mathrm{Ni}$ & 0 to 8 & 2 \\
\hline$P$ & 4,865 to 9,725 & 6,300 \\
\hline $\mathrm{Pb}$ & 0 to 3.3 & 0.9 \\
\hline $\mathrm{Rb}$ & 0.04 to 1.5 & 0.4 \\
\hline $\mathrm{Sb}$ & 0.3 to 3.3 & 2 \\
\hline $\mathrm{Se}$ & $<0.2$ to 1.6 & 0.6 \\
\hline$S i^{(b)}$ & 0 to 842 & 220 \\
\hline Sn & 0.5 to 6.4 & 3 \\
\hline $\mathrm{Ti}$ & 0 to 2 & 0.5 \\
\hline$Z n$ & 0 to 376 & 96 \\
\hline
\end{tabular}

(a) Remaining elements below limits of detection or none detected in excess of blank filter.

(b) These elements major impurities in filter medium. Uncertainty greater for these components. 
APPENDIX C

INDUSTRIAL OFF-GAS UTILIZATION DATA COLLECTION AT KAISER STEEL'S FONTANA WORKS

\author{
Prepared by \\ TRW Environmental Engineering Division \\ of \\ Redondo Beach, California
}

Subc.* B-88821-A-E 


\section{INDUSTRIAL OFF-GAS UTILIZATION DATA COLLECTION}

AT KAISER STEEL'S FONTANA WORKS

\section{INTRODUCTION}

The off gases from blast furnaces and basic oxygen furnaces contain significant amounts of carbon monoxide. This carbon monoxide is currently used as low Btu fuel or disposed of by flaring. It might be feasible to utilize the carbon monoxide as a feed stock in chemical production if quantities are availble and gas treatment is not too expensive.

The first two steps in determining feasibility of carbon monoxide utilization are the determination of the quantity of the gas available and the quantification of impurities present in the gas.

During a two-week field testing effort in December, 1979 (12/3/79 through $12 / 14 / 79)$ and a two-day effort in February 1980 (1/31/80 to 2/1/80) personnel from TRW Environmental Engineering Division performed emission tests at Kaiser Steel Company's Fontana California mill to determine the quantities and constituents of blast furnace and basic oxygen furnace off gases. The testing included sampling for particulates, particle size distribution, major and minor gaseous constituents, quantitative and semiquantitative organic analysis, analysis of inorganic anions in condensate, and elemental scan and specific metals analysis of particulates. The testing was done at two blast furnaces, (\#3 and \#4) and two Basic Oxygen plant (BOP) furnaces (BOP II, furnaces \#5 and \#6). 


\section{$\underline{\text { RESULTS }}$}

The results of the testing at Kaiser Steel's Fontana California plant are summarized in the following tables and figures. Table C.1 summarizes the particulate sampling tests at blast furnances \#3 and \#4. Table C.2 summarizes the particulate data collected at furnaces \#5 and \#6 of the Basic 0xygen Plant (BOP)II. Since gas flow, moisture, and temperature data were collected in conjunction with the particulate tests, these data are also presented in Tables C.1 and C.2.

The particle sizing results are shown in Figures C.1 and C.2 for blast furnaces \#3 and \#4, respectively. The presence of a significant amount of water droplets in the gas stream at BOP II precluded particle sizing at this location.

The results of hydrocarbon analys is at the four locations are summarized in Table C.3. Table C.3A is a numerical sequence of the various heats at the basic oxygen furnace (BOF).

The concentrations of the major gas constituents are summarized graphically in Figures C.3 through C.10. Figures $C .3$ and C.4 show the concentrations of these gases at blast furnace \#3 on 12/12/79 and 12/13/79. Figures $C .5$ and C. 6 show the gas concentrations at blast furnace \#4 on 12/4/79 and 12/5/79. Figures $C .6$ and $C .7$ show the concentrations of the major gases throughout two heats on $12 / 7 / 79$ at furnace \#6 of BOP II. Figures C.8 and C.9 show the gas concentrations throughout two heats on 12/10/79, and 12/11/79 at furnace \#5.

Table C.4 sumarizes the results of the minor gas samples taken at the four locations. Extremely low concentrations of some of these gaseous constituents made quantification very difficult. In the case of the halogens none were detected at any of the locations. The concentrations of $\operatorname{COS}$ and $\mathrm{CS}_{2}$ were so low that meaningful quantifications could be made at only one location. On 12/5/79 the wind was blowing in gusts up to 50 miles per hour at the plant. As a result, some of the blanks were higher than the samples for the reduced sulfur gases. The results of inorganic analysis of condensate are summarized in Table C.5. This represents the analysis for anions in the deionized water 
TABLE C.1. Particulate Results for Blast Furnace and Basic 0xygen Furnace

\begin{tabular}{|c|c|c|c|c|c|c|c|c|c|}
\hline \multirow{2}{*}{\multicolumn{2}{|c|}{ Run Number }} & \multicolumn{2}{|c|}{ KBF4-1 } & \multicolumn{2}{|c|}{ KBF4-2 } & \multicolumn{2}{|c|}{$K B O P-1(a)$} & \multicolumn{2}{|c|}{$K B O P-2^{(a)}$} \\
\hline & & $\begin{array}{l}\text { English } \\
\text { Units } \\
\end{array}$ & $\begin{array}{l}\text { Metric } \\
\text { Units } \\
\end{array}$ & $\begin{array}{l}\text { English } \\
\text { Units } \\
\end{array}$ & $\begin{array}{l}\text { Metric } \\
\text { Units } \\
\end{array}$ & $\begin{array}{l}\text { English } \\
\text { Units }\end{array}$ & $\begin{array}{l}\text { Metric } \\
\text { Units }\end{array}$ & $\begin{array}{l}\text { English } \\
\text { Units } \\
\end{array}$ & $\begin{array}{l}\text { Metric } \\
\text { Units } \\
\end{array}$ \\
\hline I. & Date/Heat Numbers & $12 / 4 / 79$ & $12 / 4 / 79$ & $12 / 5 / 79$ & $12 / 7 / 79$ & $\begin{array}{l}1 \text { and } 2 \\
12 / 7 / 79\end{array}$ & $\begin{array}{l}1 \text { and } 2 \\
12 / 7 / 79\end{array}$ & $\begin{array}{l}4,5,6 \\
12 / 10 / 79\end{array}$ & $\begin{array}{l}4,5,6 \\
12 / 10 / 79\end{array}$ \\
\hline \multirow[t]{15}{*}{ II. } & Stack Parameters & & & & & & & & \\
\hline & PST - Static Pressure, $" \mathrm{Hg}(\mathrm{mmHg})$ & 2.2 & 55.80 & 1.00 & 25.4 & 0.011 & 0.279 & 0.007 & 0.118 \\
\hline & Ps - Stack Gas Pressure, "Hg Absolute & 29.40 & 746.80 & 29.04 & 737.96 & 28.98 & 736.11 & 29.00 & 736.78 \\
\hline & $\% \mathrm{CO}_{2}-\mathrm{vol} \%$ Dry & 15.9 & 15.9 & 21.28 & 21.28 & 19.27 & 19.27 & 20.21 & 20.21 \\
\hline & $\% \mathrm{CO}_{2}-\operatorname{vol} \%$ Dry & 2.47 & 2.47 & 2.46 & 2.46 & 6.02 & 6.02 & 6.00 & 6.00 \\
\hline & $\% \mathrm{CO}_{2}-$ vol\% Dry & 20.7 & 20.7 & 29.15 & 29.15 & 18.49 & 18.49 & 24.62 & 24.62 \\
\hline & $\% \mathrm{CO}_{2}-\operatorname{vol} \%$ Dry & 51.7 & 51.7 & 43.13 & 43.13 & 56.22 & 56.22 & 49.17 & 49.17 \\
\hline & Ts - Average Stack temperature ${ }^{\circ} \mathrm{F}\left({ }^{\circ} \mathrm{C}\right)$ & 110.0 & 43.34 & 110.00 & 43.34 & 141.10 & 60.62 & 147.60 & 64.23 \\
\hline & $\approx \mathrm{H}_{2} \mathrm{O}-\%$ Mo isture in Stack Gas, by Volume & 7.29 & 7.29 & 7.21 & 7.21 & 21.0 & 21.0 & 24.5 & 24.5 \\
\hline & As - Stack Area, $\mathrm{ft}^{2}\left(\mathrm{M}^{2}\right)$ & 23.758 & 2.207 & 23.758 & 2.207 & 33.18 & 3.08 & 33.18 & 3.08 \\
\hline & $\begin{array}{l}\text { Md - Molecular weight of stack gas, dry } \\
\text { basis }\end{array}$ & 29.647 & 29.647 & 30.468 & 30.468 & 31.32 & 31.32 & 31.47 & 31.47 \\
\hline & $\begin{array}{l}\text { Ms - Molecular Weight of Stack Gas, Wet } \\
\text { basis }\end{array}$ & 28.739 & 28.739 & 29.496 & 29.496 & 28.526 & 28.526 & 28.173 & 28.173 \\
\hline & Vs - Stack Gas Velocity, $\mathrm{ft} / \mathrm{sec},(\mathrm{m} / \mathrm{sec})$ & 48.854 & 14.891 & 46.863 & 14.284 & 57.767 & 17.607 & 50.683 & 15.448 \\
\hline & $\begin{array}{l}\text { Qa - Stack Veolumetric Flow at Stack } \\
\text { Conditions, acfm }\left(\mathrm{Nm}^{\mathrm{w}} / \mathrm{min}\right)\end{array}$ & 69640 & 1972.0 & 66803 & 1891.7 & 115001.6 & 3256.5 & 100899.9 & 2857.2 \\
\hline & $\begin{array}{l}\text { Qs - Stack Gas Volumetric Elow at Standard } \\
\text { Conditions, DSCFM }\left(\mathrm{Nm}^{2} / \mathrm{min}\right)\end{array}$ & 58767 & 1664.1 & 55730 & 1578.1 & 77298.3 & 2188.9 & 64172.95 & 1817.2 \\
\hline
\end{tabular}

III. Test Conditions
$\mathrm{Pb}$ - Barometric Pressure, "Hg ( $\mathrm{mmHg}$ )

$\begin{array}{llllllll}29.24 & 742.70 & 28.97 & 735.84 & 28.97 & 735.84 & 29.00 & 736.60 \\ 0.250 & 6.35 & 0.184 & 4.67 & 0.245 & 6.223 & 0.245 & 6.22\end{array}$
Dn - Sampling Nozzle Diameter, in. (m)

(a) Due to large amounts of water droplets in gas stream, moisture could not be determined by condensation method. The moisture figures used are saturation moisture concentration at stack temperature measured. 


\section{TABLE C.1. (contd)}

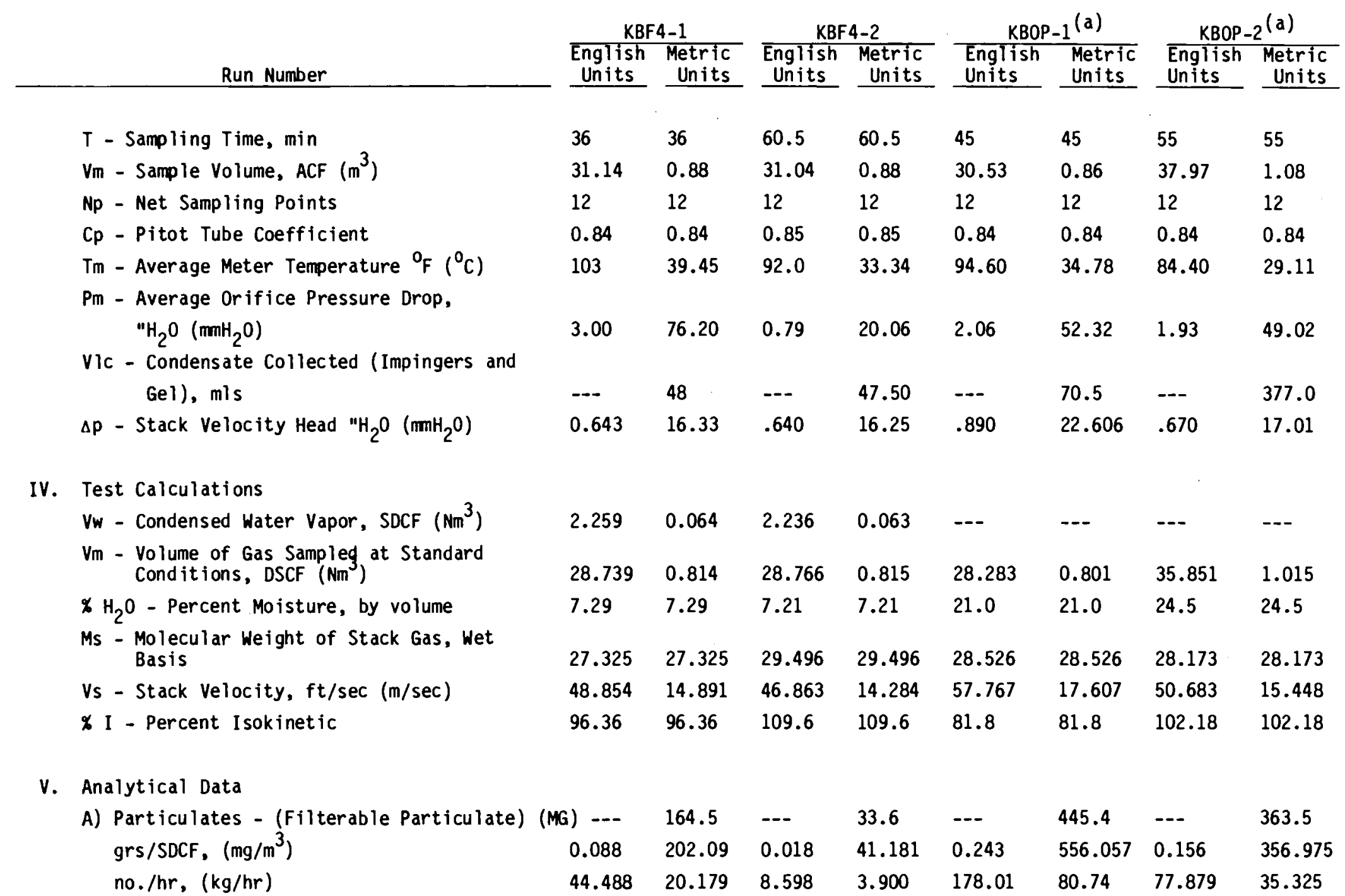

(a) Due to large amounts of water droplets in gas stream, moisture could not be determined by condensation method. The mo isture figures used are saturation mo isture concentration at stack temperature measured. 
TABLE C.2. Particulate Results for Blast Furnace and Basic 0xygen Furnace

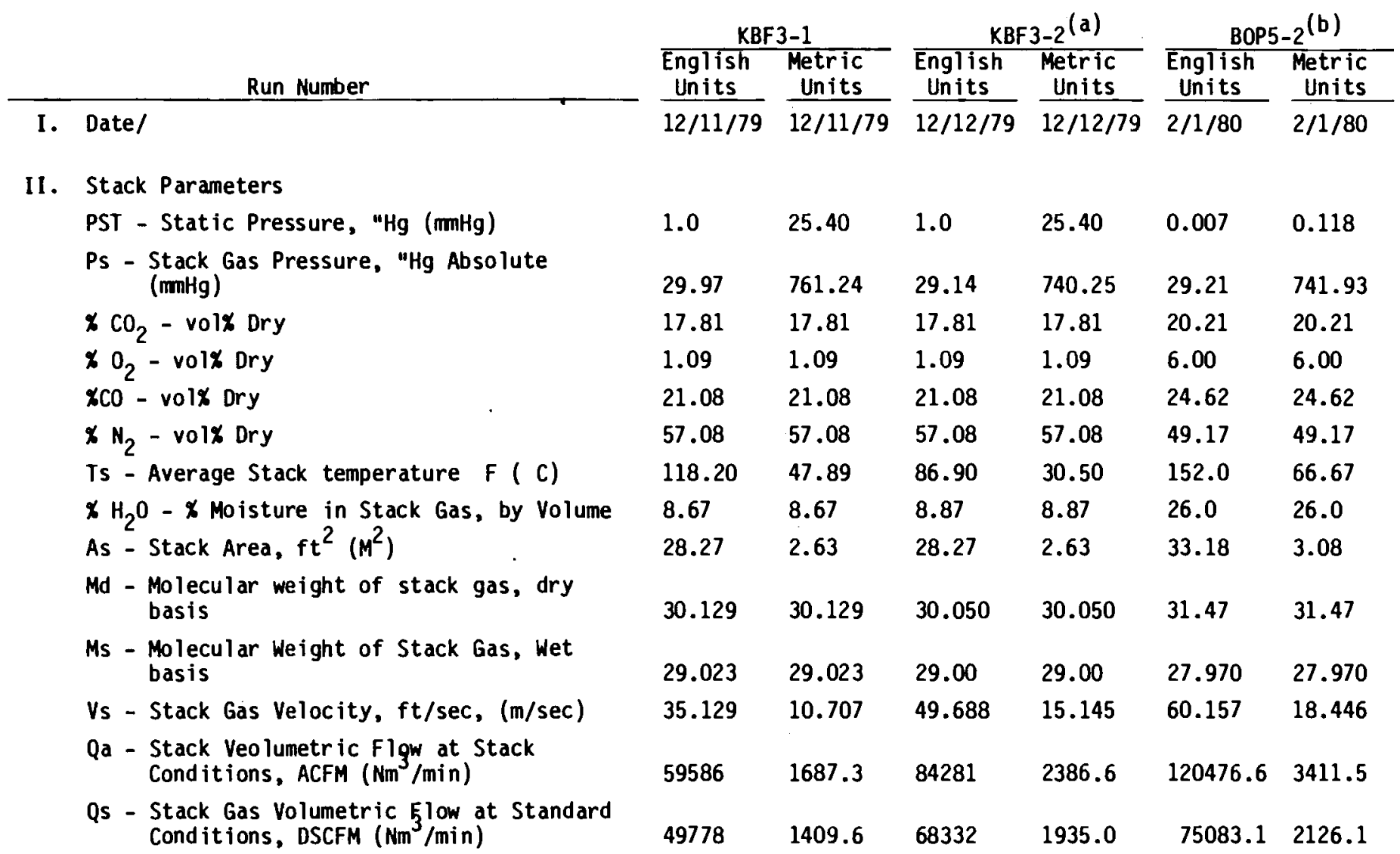

III. Test Conditions
$\mathrm{Pb}$ - Barometric Pressure, " $\mathrm{Hg}(\mathrm{mmHg})$
28.90
734.06
29.07
738.38
29.20
741.68
Dn - Sampling Nozzle Diameter, in. (mm)
0.245
6.22
0.245
$6.223 \quad 0.250$
6.35

(a) Since no gas composition data is available for $12 / 11 / 79$, the gas composition of $12 / 12 / 79$ was used for both particulate runs at blast furnace number 3.

(b) Due to large amounts of water droplets in gas stream, moisture could not be determined by condensation method. The moisture figures used are saturation moisture concentration at stack temperature measured. 
TABLE C.2. (contd)

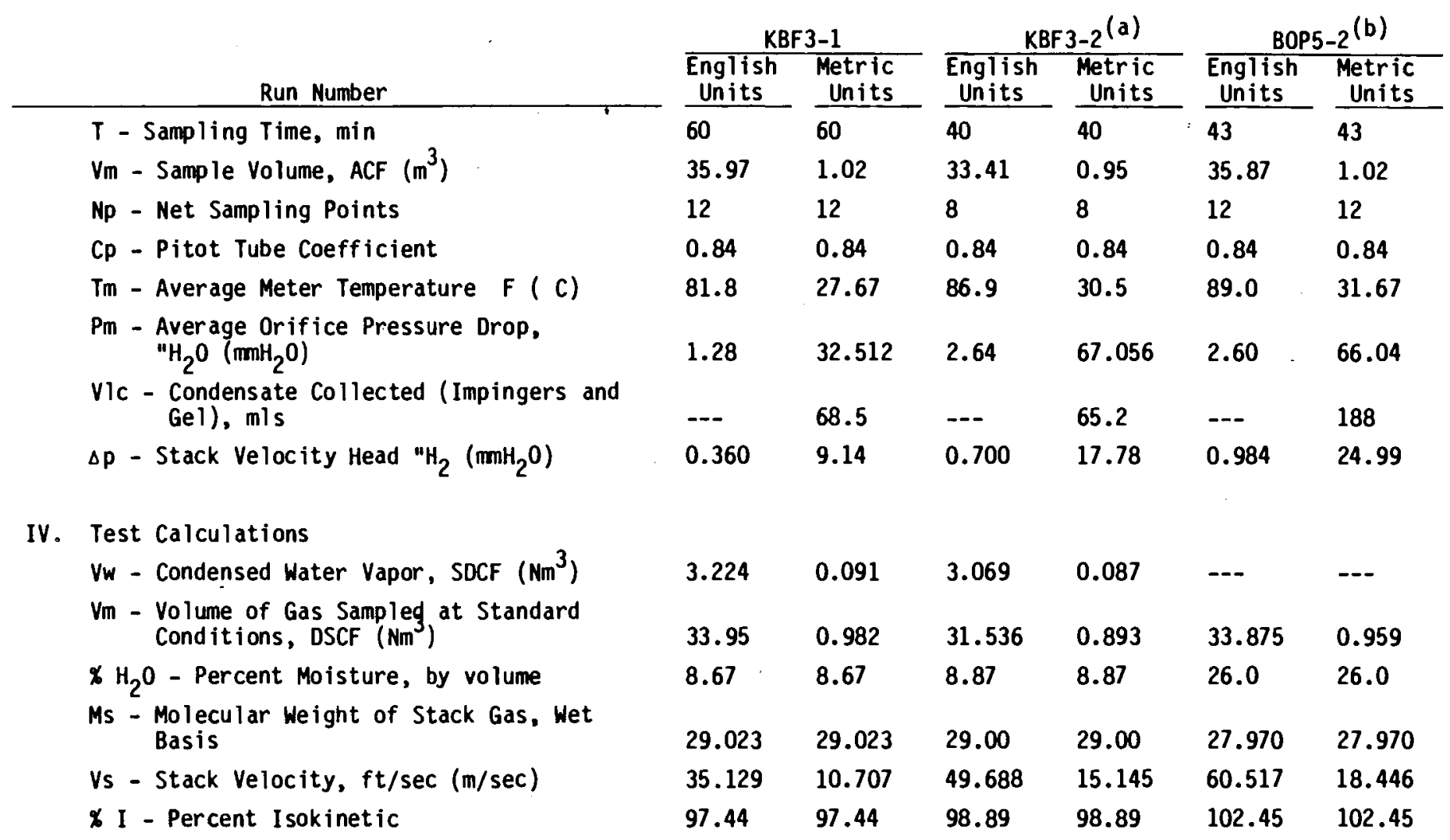

V. Analytical Data

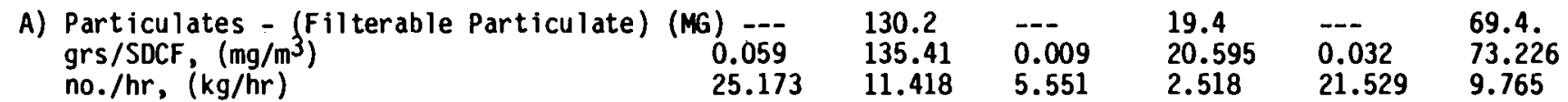

(a) Since no gas composition data is available for $12 / 11 / 79$, the gas composition of $12 / 12 / 79$ was used for both particulate runs at blast furnace number 3.

(b) Due to large amounts of water droplets in gas stream, moisture could not be determined by condensation method. The moisture figures used are saturation mo isture concentration at stack temperature measured. 


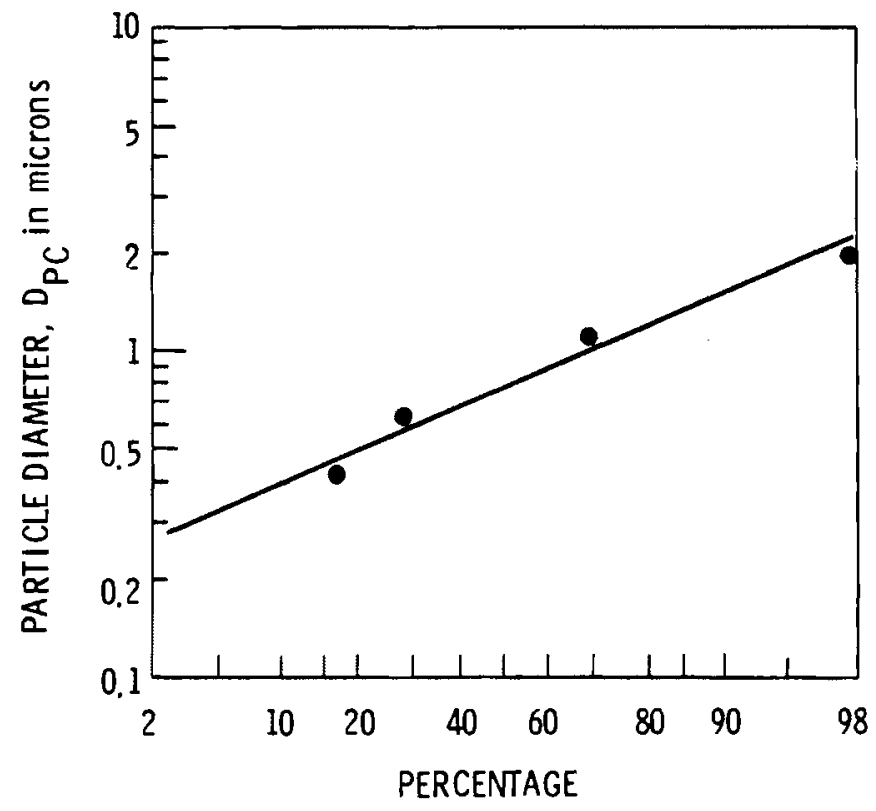

FIGURE C.1. Particle Size Distribution, B last Furnace \#3, 12/12/79

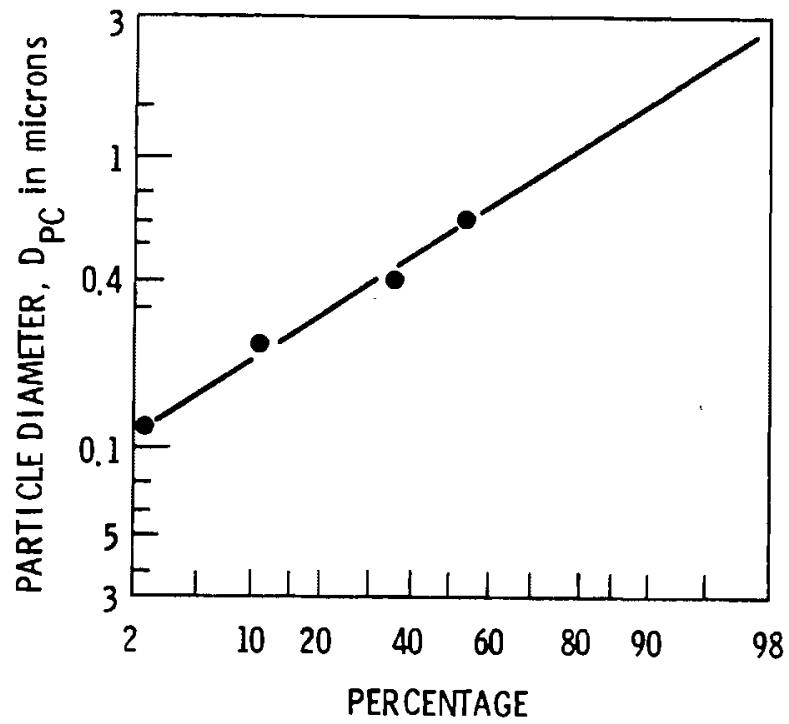

FIGURE C.2. Particle Size Distribution, Blast Furnace \#4, 12/5/79 
TABLE C.3. Hydrocarbons in Gas Stream

\begin{tabular}{|c|c|c|c|c|c|}
\hline \multirow{2}{*}{ Test No. } & \multirow[b]{2}{*}{ Date } & \multicolumn{4}{|c|}{ Hydrocarbon Concentration (ppmv) } \\
\hline & & $\overline{\mathrm{CH}}_{4}$ & $\underline{\mathrm{C}}_{2} \mathrm{H}_{6}$ & $\underline{C}_{2} \underline{H}_{4}$ & $\mathrm{CH}_{3} \mathrm{OH}$ \\
\hline KBOP-1 & $12 / 10 / 79$ & 1.0 & 1.2 & N.D. & N.D. \\
\hline KBOP-2 & $12 / 11 / 79$ & 2.2 & 3.1 & N.D. & 10 \\
\hline KBF3-1 & $12 / 11 / 79$ & 474 & 0.5 & 3.0 & N.D. \\
\hline KBF3-2 & $12 / 12 / 79$ & 158 & 0.5 & 2.2 & N.D. \\
\hline KBF4-2 & $12 / 15 / 79$ & 74 & 3.3 & N.D. & N.D. \\
\hline
\end{tabular}

TABLE C.3A. Heats Tested At BOF

\begin{tabular}{|c|c|c|c|c|}
\hline $\begin{array}{l}\text { Furnace } \\
\text { Number }\end{array}$ & $\begin{array}{c}\text { Heat } \\
\text { Number }\end{array}$ & Date & Time & $\begin{array}{c}\text { Kaiser } \\
\text { Heat Number }\end{array}$ \\
\hline 6 & 1 & $12-7-79$ & $3: 37-4: 02$ & 614410 \\
\hline 6 & 2 & $12-7-79$ & $6: 10-6: 3-$ & 614411 \\
\hline 5 & 3 & $12-10-79$ & $12: 30-12: 39$ & 514542 \\
\hline 5 & 4 & $12-10-79$ & $12: 38-12: 43$ & 514542 \\
\hline 5 & 5 & $12-10-79$ & $2: 45-3: 05$ & 514545 \\
\hline 5 & 6 & $12-10-79$ & $4: 44-5: 03$ & 514546 \\
\hline 5 & 7 & $12-11-79$ & $11: 05-11: 22$ & -- \\
\hline 5 & 8 & $12-11-79$ & $4: 05-4: 25$ & 514563 \\
\hline 5 & 9 & $1-31-80$ & $11: 17-11: 37$ & 515278 \\
\hline 5 & 10 & $1-31-80$ & $13: 03-13: 18$ & 515280 \\
\hline 5 & 11 & $1-31-80$ & $2: 04-2: 24$ & 515281 \\
\hline 5 & 11 & $1-31-80$ & $2: 04-2: 24$ & 515281 \\
\hline 5 & 12 & $1-31-80$ & $3: 29-3: 48$ & 515282 \\
\hline 5 & 13 & $2-1-80$ & $6: 36-6: 58$ & 515291 \\
\hline 5 & 14 & $2-1-80$ & $9: 13-9: 36$ & 515292 \\
\hline 5 & 15 & $2-1-80$ & $1: 18-1: 38$ & 515294 \\
\hline
\end{tabular}




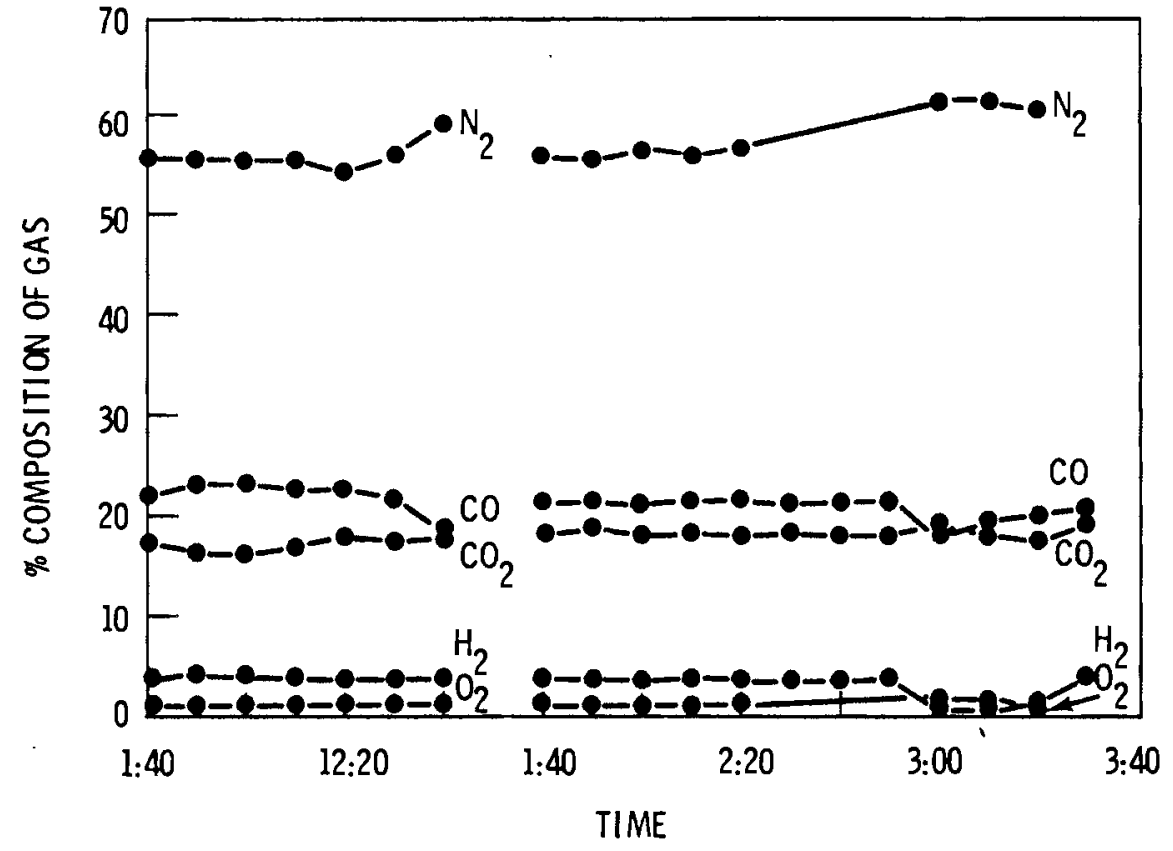

FIGURE C.3. Blast Furnace \#3

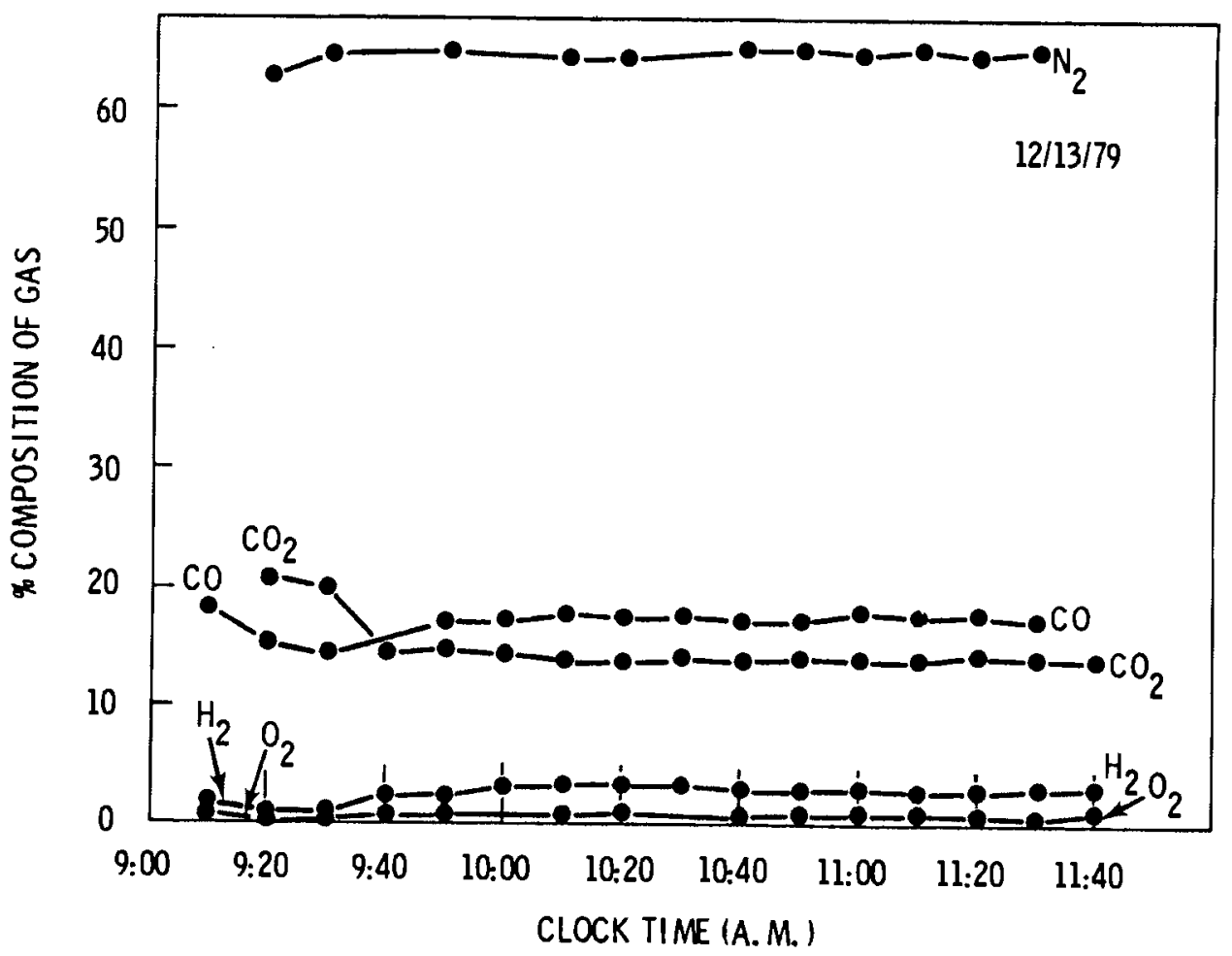

FIGURE C.4. Blast Furnace \#3 

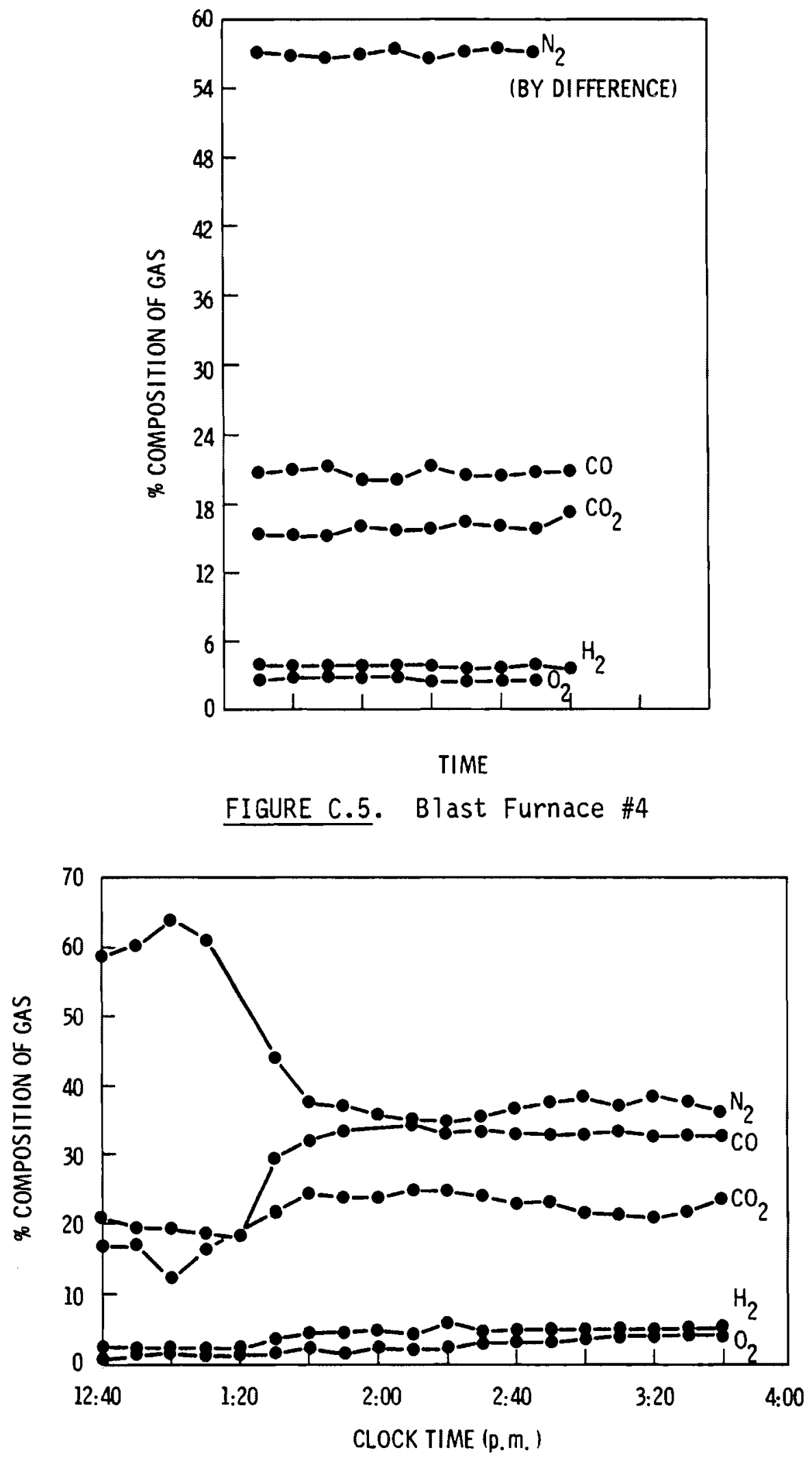

FIGURE C.6. Blast Furnace \#4

$$
\text { C. } 10
$$




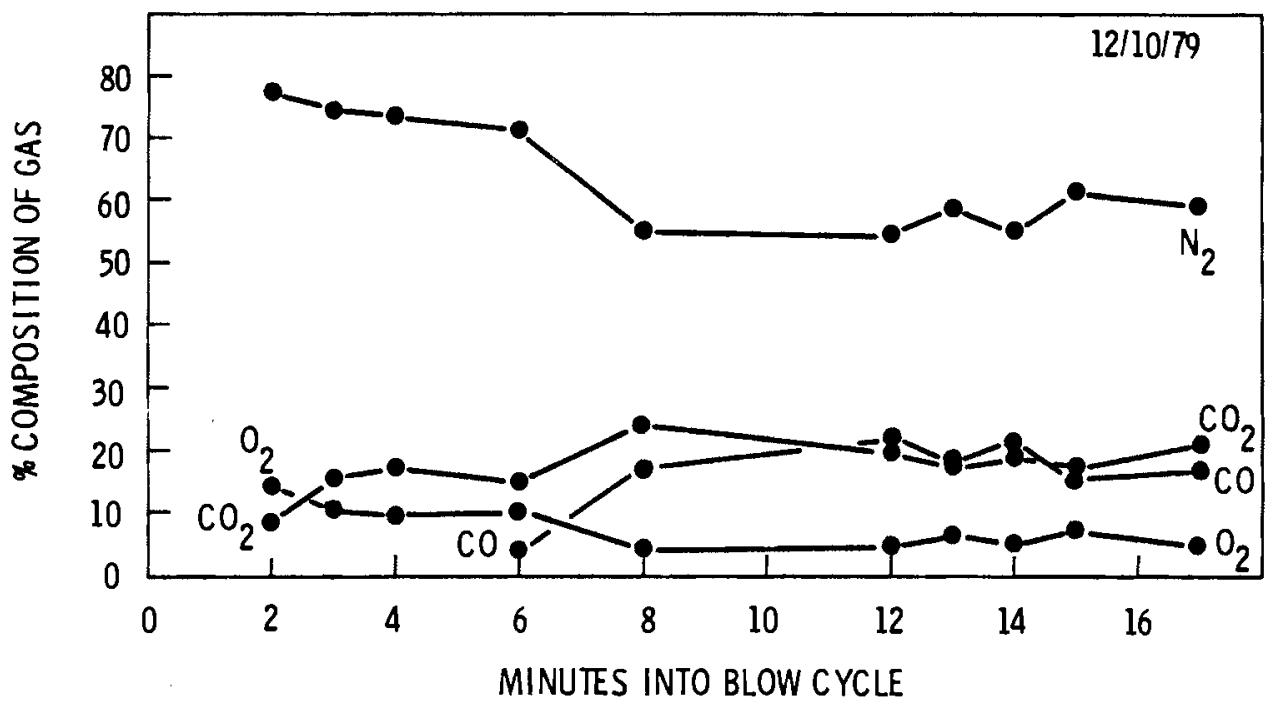

FIGURE C.7. Basic Oxygen Furnace \#5, Heat \#5

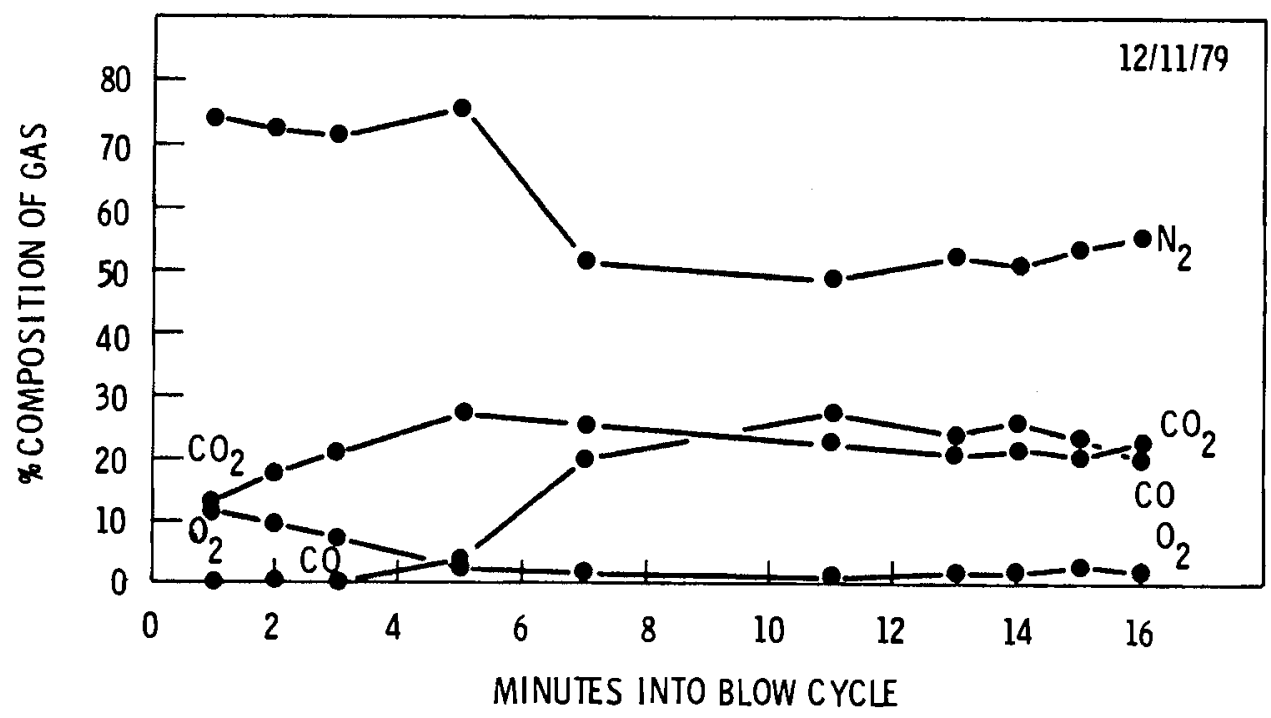

FIGURE C.8. Basic 0xygen Furnace \#5, Heat \#8 


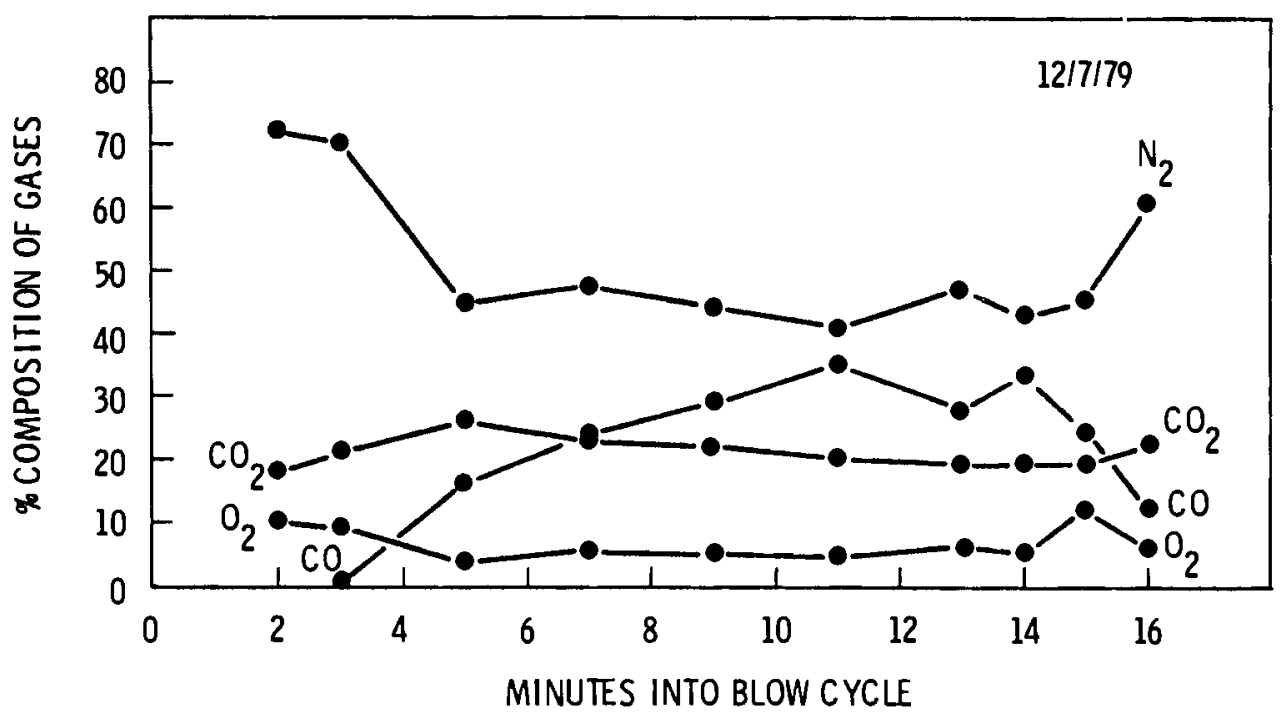

FIGURE C.9. Basic Oxygen Furnace \#6, Heat \#1

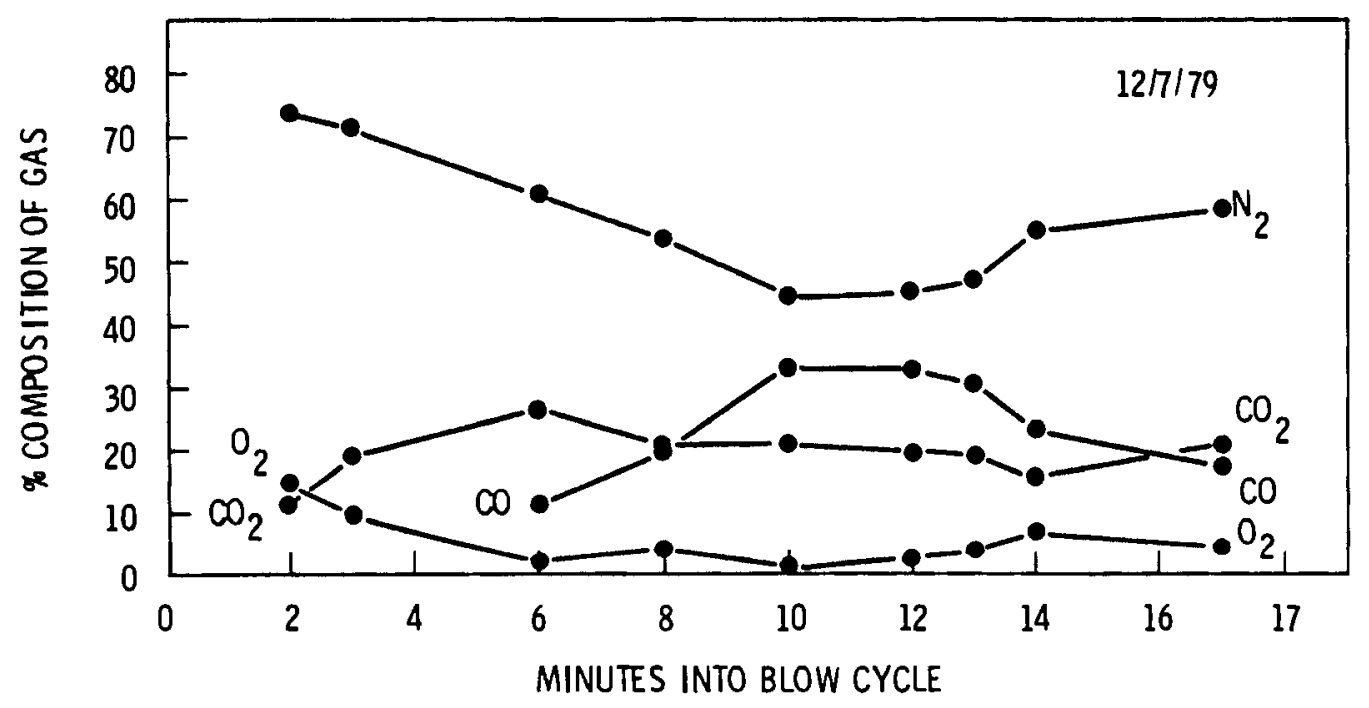

FIGURE C.10. Basic 0xygen Furnace \#6, Heat \#2 
TABLE C.4. Minor Gas Constituents

Gas

Constituent

$\mathrm{SO}_{2}$

NOX

$\mathrm{H}_{2} \mathrm{~S}$

$\cos$

$\mathrm{CS}_{2}$

$\mathrm{NH}_{3}$

$\mathrm{PH}_{3}$

$\mathrm{Cl}_{2}$

Br2

I2

HCN

\section{Concentration}

$\mathrm{Mg} / \mathrm{nm}^{3}$

ppmv

$\mathrm{Mg} / \mathrm{nm}^{3}$

ppmv

$\mathrm{Mg} / \mathrm{nm}^{3}$

ppmv

$\mathrm{Mg} / \mathrm{nm}^{3}$

ppmv

$\mathrm{Mg} / \mathrm{nm}^{3}$

ppmv

$\mathrm{Mg} / \mathrm{nm}^{3}$

ppmv

$\mathrm{Mg} / \mathrm{nm}^{3}$

ppmv

$\mathrm{Mg} / \mathrm{nm}^{3}$

ppmv

$\mathrm{Mg} / \mathrm{nm}^{3}$

ppmv

$\mathrm{Mg} / \mathrm{nm}^{3}$

ppmv

$\mathrm{Mg} / \mathrm{nm}^{3}$

ppmv
Test Number

\begin{tabular}{|c|c|c|c|}
\hline KBF3-1 & KBF3-2 & KBF4-1 & KBF4-2 \\
\hline $\begin{array}{r}23.0 \\
8.7\end{array}$ & $\begin{array}{l}54.8 \\
20.6\end{array}$ & $\begin{array}{r}12.0 \\
4.5\end{array}$ & $\begin{array}{r}127.9 \\
48.1\end{array}$ \\
\hline $\begin{array}{r}16.3 \\
8.5\end{array}$ & $\begin{array}{l}\text { N.D. } \\
\text { N.D. }\end{array}$ & & $\begin{array}{r}11.8 \\
6.2\end{array}$ \\
\hline
\end{tabular}

\section{0}

16.0

90.0

64.0

2.0

0.6

N.D.

N.D.

$42.0 \quad 43.0$

17.0

17.0

0.43

0.60

N.D.

N.D.

N.D.

N.D.

N.D.

N.D.

N.D.

N.D.

N.D.

N.D.

N.D.

N.D.

N.D.

N.D.

N.D.

N.D.

N.D.

N.D.

N.D.

N.D.

N.D.

N.D.

N.D.

N.D.

N.D.

N.D.

N.D.

N.D.

0.70

3.1

2.8

0.33

0.64

0.29 
TABLE C.4A. Minor Gas Constituents

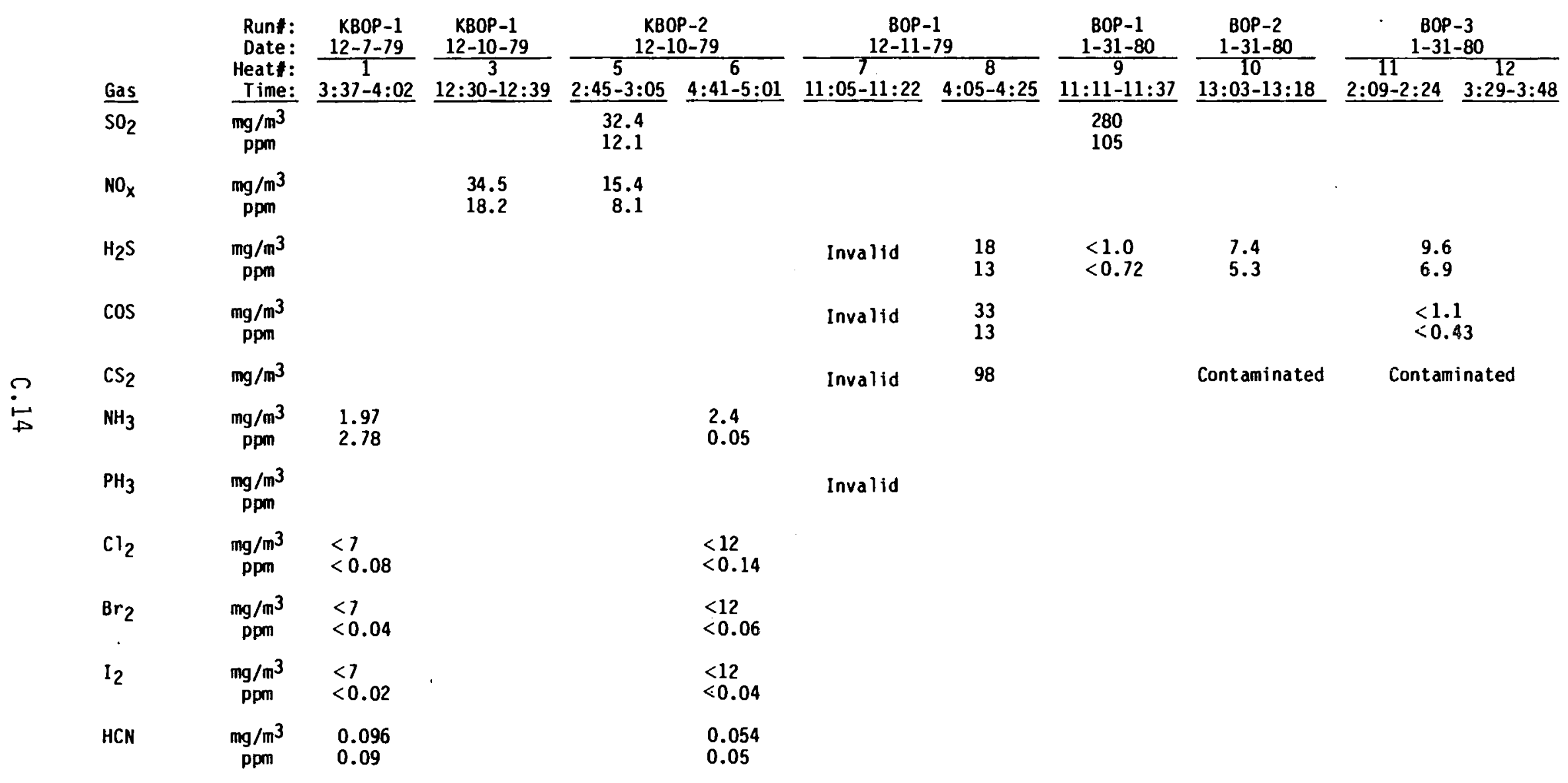


TABLE C.5. Condensate Anions

Test Number

\begin{tabular}{|c|c|c|c|c|c|c|c|}
\hline Anion & Conc. & $\begin{array}{l}\text { Heats } 1 \& 2 \\
\text { KBOP }-1\end{array}$ & $\begin{array}{l}\text { Heats } 4,5,6 \\
\text { KBOP-2 }\end{array}$ & KBF 3-1 & KBF $3-2$ & KBF4-1 & $\mathrm{KBF} 4-2$ \\
\hline I & $\begin{array}{l}\mathrm{Mg} / \mathrm{m}^{3} \\
\mathrm{ppmv}\end{array}$ & $\begin{array}{l}\text { N.D. } \\
\text { N.D. }\end{array}$ & $\begin{array}{l}\text { N.D. } \\
\text { N.D. }\end{array}$ & $\begin{array}{l}\text { N.D. } \\
\text { N.D. }\end{array}$ & $\begin{array}{l}\text { N.D. } \\
\text { N.D. }\end{array}$ & $\begin{array}{l}\text { N.D. } \\
\text { N.D. }\end{array}$ & $\begin{array}{l}\text { N.D. } \\
\text { N.D. }\end{array}$ \\
\hline $\mathrm{Br}$ & $\begin{array}{l}\mathrm{Mg} / \mathrm{m}^{3} \\
\mathrm{ppmv}\end{array}$ & $\begin{array}{l}\text { N.D. } \\
\text { N.D. }\end{array}$ & $\begin{array}{l}1.5 \\
0.4\end{array}$ & $\begin{array}{l}\text { N.D. } \\
\text { N.D. }\end{array}$ & $\begin{array}{l}\text { N.D. } \\
\text { N.D. }\end{array}$ & $\begin{array}{l}\text { N.D. } \\
\text { N.D. }\end{array}$ & $\begin{array}{l}\text { N.D. } \\
\text { N.D. }\end{array}$ \\
\hline $\mathrm{Cl}$ & $\begin{array}{l}\mathrm{Mg} / \mathrm{m}^{3} \\
\mathrm{ppmv}\end{array}$ & $\begin{array}{l}1.7 \\
1.2\end{array}$ & $\begin{array}{l}18.0 \\
12.0\end{array}$ & $\begin{array}{l}\text { N.D. } \\
\text { N.D. }\end{array}$ & $\begin{array}{l}\text { N.D. } \\
\text { N.D. }\end{array}$ & $\begin{array}{l}\text { N.D. } \\
\text { N.D. }\end{array}$ & $\begin{array}{l}\text { N.D. } \\
\text { N.D. }\end{array}$ \\
\hline $\mathrm{F}$ & $\begin{array}{l}\mathrm{Mg} / \mathrm{m}^{3} \\
\mathrm{ppmv}\end{array}$ & $\begin{array}{l}0.19 \\
0.24\end{array}$ & $\begin{array}{l}2.02 \\
2.56\end{array}$ & $\begin{array}{l}0.02 \\
0.02\end{array}$ & $\begin{array}{l}0.05 \\
0.06\end{array}$ & $\begin{array}{l}0.02 \\
0.03\end{array}$ & $\begin{array}{l}0.02 \\
0.03\end{array}$ \\
\hline $\mathrm{SO}_{4}$ & $\begin{array}{l}\mathrm{Mg} / \mathrm{m}^{3} \\
\mathrm{ppmv}\end{array}$ & $\begin{array}{l}3.59 \\
0.9\end{array}$ & $\begin{array}{l}34.8 \\
8.7^{2}\end{array}$ & $\begin{array}{l}1.52 \\
0.38\end{array}$ & $\begin{array}{l}1.35 \\
0.34\end{array}$ & $\begin{array}{l}2.1 \\
0.52\end{array}$ & $\begin{array}{l}2.1 \\
0.52\end{array}$ \\
\hline $\mathrm{PO}_{4}$ & $\begin{array}{l}\mathrm{Mg} / \mathrm{m}^{3} \\
\mathrm{ppmv}\end{array}$ & $\begin{array}{l}0.11 \\
0.03\end{array}$ & $\begin{array}{l}0.47 \\
0.12\end{array}$ & $\begin{array}{l}0.11 \\
0.03\end{array}$ & $\begin{array}{l}\text { N.D. } \\
\text { N.D. }\end{array}$ & $\begin{array}{l}\text { N.D. } \\
\text { N.D. }\end{array}$ & $\begin{array}{l}\text { N.D. } \\
\text { N.D. }\end{array}$ \\
\hline $\mathrm{NO}_{3}$ & $\begin{array}{l}\mathrm{Mg} / \mathrm{m}^{3} \\
\mathrm{ppmv}\end{array}$ & $\begin{array}{l}0.06 \\
0.02\end{array}$ & $\begin{array}{l}1.72 \\
0.67\end{array}$ & $\begin{array}{l}0.01 \\
0.004\end{array}$ & $\begin{array}{l}0.03 \\
0.01\end{array}$ & $\begin{array}{l}0.02 \\
0.01\end{array}$ & $\begin{array}{l}0.02 \\
0.01\end{array}$ \\
\hline
\end{tabular}

N.D. denotes that no trace of this Anion was detected.

impinger solutions from the two particle sizing tests at the blast furnaces, and the particulate test at furnace \#6 of BOP II because the particulates were captured in the impingers in that test.

An elemental analysis of the particulates from the four locations was done by spark source mass spectrometry. These data are summarized in Table C.6. The particulates were also analyzed for selected metals by atomic absorption spectroscopy. These data are summarized in Tables C.7 and C.7A. 
TABLE C.6. Spark Source Mass Spectrographic Analys is (concentration in ppm by weight of ashed particulate)(a)

\begin{tabular}{|c|c|c|c|c|}
\hline & KBF3-1 & KBF4-1 & $K B O P-1$ & $K B O P-2$ \\
\hline Uranium & $<5$ & $<8$ & $<3$ & 5 \\
\hline Thorium & 6 & 12 & $<4$ & 11 \\
\hline Bismuth & 52 & 89 & 14 & 5 \\
\hline Lead & MC & MC & 760 & MC \\
\hline Tungsten & 15 & 57 & 7 & 1 \\
\hline Neodymium & 6 & $\leq 3$ & $\leq 1$ & \\
\hline Praseodymium & 3 & 3 & 0.5 & 0.7 \\
\hline Cerium & 17 & 15 & 1 & 2 \\
\hline Lanthanum & 31 & 12 & 2 & 2 \\
\hline Barium & MC & MC & 200 & 72 \\
\hline Cesium & 25 & 170 & 15 & 10 \\
\hline Iodine & 3 & 2 & 0.5 & 1 \\
\hline Tellurium & 5 & 21 & $\leq 2$ & $\leq 1$ \\
\hline Antimony & 13 & 40 & 32 & 13 \\
\hline Tin & 270 & MC & 940 & 610 \\
\hline Indium & STD & STD & STD & STD \\
\hline Cadmium & 22 & 85 & 76 & 49 \\
\hline Silver & 7 & 48 & 35 & 62 \\
\hline Molybdenum & 33 & 320 & 120 & 75 \\
\hline Niobium & 14 & 15 & 9 & 3 \\
\hline Zirconium & 19 & $\leq 15$ & 3 & 4 \\
\hline Yttrium & 9 & 2 & $\leq 0.6$ & 2 \\
\hline Strontium & 270 & 410 & 270 & 110 \\
\hline Rubidium & 58 & 440 & 360 & 260 \\
\hline Bromine & 460 & 400 & 160 & 140 \\
\hline Selen ium & 33 & 56 & 51 & 82 \\
\hline Arsenic & 62 & 110 & 350 & 56 \\
\hline Germanium & 2 & 6 & 9 & 2 \\
\hline Gallium & 10 & 10 & 34 & 44 \\
\hline Zinc & $M C$ & MC & $M C$ & $M C$ \\
\hline Copper & MC & $M C$ & MC & $M C$ \\
\hline
\end{tabular}


TABLE C.6. (contd)

Nickel

$\frac{K B F 3-1}{M C} \quad \frac{K B F 4-1}{M C} \quad \frac{K B O P-1}{M C} \quad \frac{K B O P-2}{M C}$

Cobalt

$23 \quad 390$

Iron

Manganese

Chromium

Vanadium

MC

$M C$

MC

22

Titanium

784

Scandium

Calcium

Potassium

Chlorine

Sulfur

Phosphorous

Silicon

Aluminum

Magnes ium

Sodium

Fluorine

Boron

$\leq 0.4$

$M C$

$M C$

MC

$M C$

MC

MC

32

51

MC

$M C$

$M C$

$M C$

MC

$M C$

31

22

19

81

350

$\leq 0.5$

MC

$\leq 0.8$

$M C$

$M C$

$M C$

$M C$

$M C$

$M C$

$M C$

$M C$

MC

MC

$M C$

710

$M C$

MC

$M C$

MC

$M C$

$M C$

$M C$

410

220

$M C$

$M C$

MC

MC

$M C$

$M C$

$M C$

380

$M C$

MC

$M C$

$M C$

630

48

390

160

Beryllium

0.5

0.9

Lithium

2

4

15

9

Weights of Ashed Particulate Collected in Tests

$\begin{array}{lrrrr}\text { wt on Filter } & 13.6 \mathrm{mg} & 10.5 \mathrm{mg} & 12.0 \mathrm{mg} & 1.7 \mathrm{mg} \\ \text { wt } \text { of Probe Rinse } & 103.0 \mathrm{mg} & 118.6 \mathrm{mg} & 413.6 \mathrm{mg} & 346.4 \mathrm{mg}\end{array}$

(a) MC = Major Component - more than $1000 \mathrm{ppm}$. 
TABLE C.7. Percent Composition of Ashed Particulate

$\begin{array}{lcccc}\text { Run \# } & \text { KBF4-1 } & \text { KBF3-1 } & \text { KBOP-1 } & \text { KBOP-2 } \\ \text { Date } & 12-4-79 & 12-11-79 & 12-7-79 & 12-10-79 \\ \text { Heat } & --. & --- & 1,2 & 4,5,6\end{array}$

\begin{tabular}{|c|c|c|c|c|c|}
\hline Meta 1 & Time & $15: 34-16: 10$ & $16: 13-16: 53$ & $15: 37-18: 30$ & $12: 28-17: 03$ \\
\hline $\mathrm{Na}$ & $\%$ by wt. & 2.49 & 1.28 & 6.52 & 4.27 \\
\hline K & $\%$ by wt. & 2.75 & 0.96 & 7.90 & 3.85 \\
\hline $\mathrm{Ca}$ & $\%$ by wt. & 5.99 & 3.15 & 3.67 & 2.71 \\
\hline $\mathrm{Mg}$ & $\%$ by wt. & 1.77 & 1.86 & 0.81 & 0.77 \\
\hline$A 1$ & $\%$ by wt. & 1.40 & 2.11 & 0.16 & 0.25 \\
\hline $\mathrm{Fe}$ & $\%$ by wt. & 13.2 & 12.8 & 21.6 & 20.9 \\
\hline$M n$ & $\%$ by wt. & 1.14 & 0.51 & 0.80 & 0.81 \\
\hline $\mathrm{Cr}$ & $\%$ by wt. & 0.98 & 0.13 & 0.22 & 0.16 \\
\hline $\mathrm{Pb}(\mathrm{a})$ & $\%$ by wt. & 0.49 & 0.48 & 0.056 & 0.12 \\
\hline $\mathrm{Ni}(\mathrm{a})$ & $\%$ by wt. & 5.00 & 0.58 & 0.21 & 0.13 \\
\hline $\mathrm{Cu}^{(\mathrm{a})}$ & $\%$ by wt. & 0.84 & 1.83 & 0.50 & 0.45 \\
\hline$Z n(a)$ & $\%$ by wt. & 2.46 & 4.22 & 1.01 & 0.76 \\
\hline$A s h(a)(b)$ & $\%$ by wt. & 31.1 & 64.3 & 78.9 & 78.2 \\
\hline
\end{tabular}

(a) Percent composition based on probe rinse ash only.

(b) Percent ash based on sum of probe rinse ash and Filters. 
TABLE C.7A. Element Concentration in the Gas Stream $\left(\mathrm{mg} / \mathrm{Nm}^{3}\right)$

\begin{tabular}{|c|c|c|c|c|c|}
\hline Meta 1 & $\begin{array}{l}\text { Run \# } \\
\text { Date } \\
\text { Heat } \\
\text { Time } \\
\end{array}$ & $\begin{array}{c}\text { KBF } 4-1 \\
12-4-79 \\
--- \\
15: 34-16: 10 \\
\end{array}$ & $\begin{array}{c}\text { KBF3-1 } \\
12-11-79 \\
--- \\
16: 13-16: 53 \\
\end{array}$ & $\begin{array}{c}\mathrm{KBOP}-1 \\
12-7-79 \\
1,2 \\
15: 37-18: 30 \\
\end{array}$ & $\begin{array}{c}\text { KBOP }-2 \\
12-10-79 \\
4,5,6 \\
12: 28-17: 03 \\
\end{array}$ \\
\hline $\mathrm{Na}$ & $\%$ by wt. & 1.56 & 1.09 & 24.7 & 12.0 \\
\hline$k$ & $\%$ by wt. & 1.73 & 0.82 & 34.7 & 10.8 \\
\hline $\mathrm{Ca}$ & $\%$ by wt. & 3.76 & 2.69 & 16.1 & 7.59 \\
\hline $\mathrm{Mg}$ & $\%$ by wt. & 1.11 & 1.59 & 3.55 & 2.16 \\
\hline A & $\%$ by wt. & 0.88 & 1.80 & 0.70 & 0.70 \\
\hline $\mathrm{Fe}$ & $\%$ by wt. & 8.30 & 10.91 & 94.8 & 58.5 \\
\hline Mn & $\%$ by wt. & 0.72 & 0.43 & 3.51 & 2.27 \\
\hline $\mathrm{Cr}$ & $\%$ by wt. & 0.62 & 0.11 & 0.97 & 0.45 \\
\hline $\mathrm{Pb}(\mathrm{a})$ & $\%$ by wt. & 0.31 & 0.41 & 0.25 & 0.34 \\
\hline $\mathrm{Ni}(\mathrm{a})$ & $\%$ by wt. & 3.14 & 0.49 & 0.92 & 0.36 \\
\hline $\mathrm{Cu}^{(\mathrm{a})}$ & $\%$ by wt. & 0.53 & 1.56 & 2.19 & 1.26 \\
\hline $2 n(a)$ & $\%$ by wt. & 1.55 & 3.60 & 4.43 & 2.13 \\
\hline
\end{tabular}

(a) Concentration based on probe rinse ash only. 


\section{SAMPLING LOCATIONS}

During the test program samples were taken at four locations. These locations included blast furnaces \#3 and \#4 and furnaces \#5 and \#6 of the Basic Oxygen Plant (BOP II).

The main gas ducts from blast furnaces \#3 and \#4 are horizontal ducts. The duct at blast furnace \#3 is $5.5 \mathrm{ft}$ in diameter, while the duct at blast furnace \#4 is $6 \mathrm{ft}$ in diameter. Since the gases in the duct contain a high percentage of carbon monoxide and are under a positive pressure of 1 to 3 in. of mercury, it was necessary to introduce a sealed probe through a gate valve to collect the particulate samples. Figures $C .11$ and $C .12$ are schematic diagrams of these locations.

The gases from the basic oxygen furnaces in BOP II exit through vertical ducts $78 \mathrm{in}$. in diameter. The sampling locations for these sources were on the eighth floor of the basic oxygen plant building. Figure C.13 is a diagram of these sampling locations (which are identical) and Figure C.14 is a generalized diagram of the basic oxygen furnaces. 


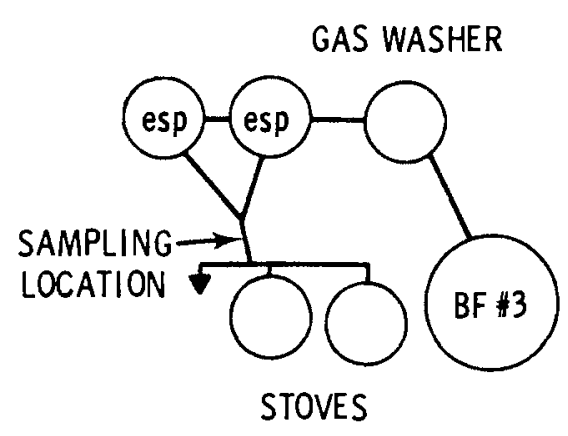

PLAN VIEW OF BF \#3 DUCTING

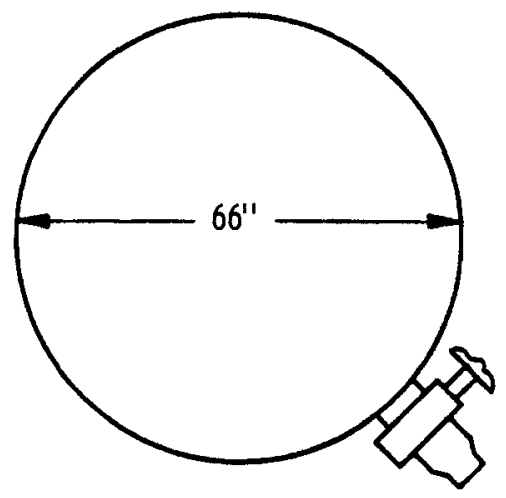

CROSS SECTION OF DUCT

TRAVERSE POINT LOCATIONS
\begin{tabular}{|c|c|c|}
\hline \multicolumn{3}{|c|}{ TRAVERSE } \\
\hline $\begin{array}{c}\text { TRAVERSE } \\
\text { POINT NUMBER }\end{array}$ & $\%$ OF & $\begin{array}{c}\text { DISTANCE } \\
\text { FROM INSIDE } \\
\text { DIAMETER }\end{array}$ \\
WALL (INCHES) \\
\hline 1 & 2.6 & 1.69 \\
2 & 8.2 & 5.39 \\
3 & 14.6 & 9.67 \\
4 & 22.6 & 14.93 \\
5 & 34.2 & 22.56 \\
6 & 65.8 & 43.44 \\
7 & 77.4 & 51.07 \\
8 & 85.4 & 56.33 \\
9 & 91.8 & 60.61 \\
10 & 97.4 & 64.31 \\
\hline
\end{tabular}

FIGURE C.11. Blast Furnace \#3 Sampling Location 


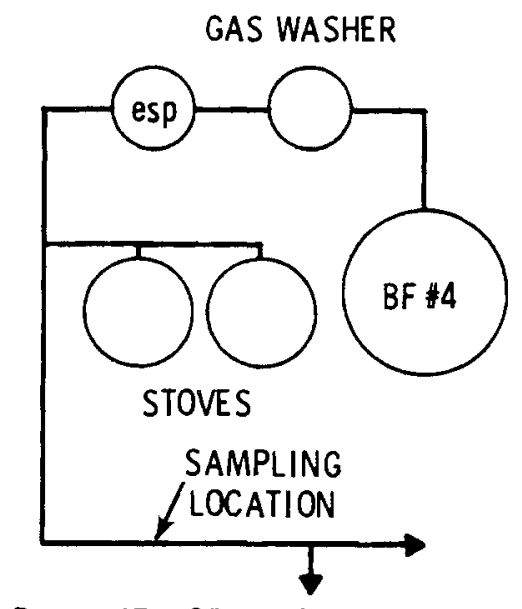

PLAN VIEW OF BF \#4 DUCTING

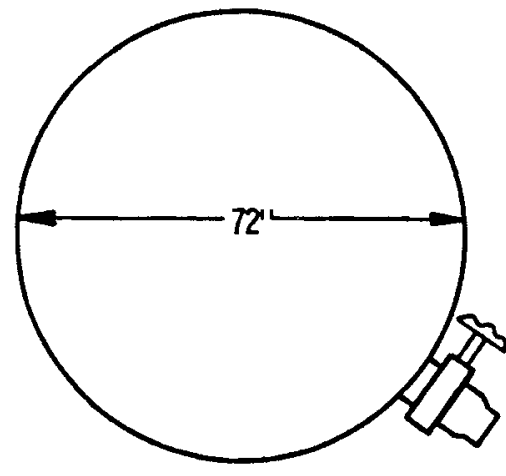

CROSS SECTION OF DUCT

\begin{tabular}{|} 
TRAVERSE POINT LOCATI ONS \\
\begin{tabular}{|c|c|c|}
\hline $\begin{array}{c}\text { TRAVERSE } \\
\text { POINT NUMBER }\end{array}$ & $\begin{array}{c}\text { \% OF } \\
\text { DIAMETER }\end{array}$ & $\begin{array}{c}\text { DISTANCE } \\
\text { FROM INSIDE } \\
\text { WALL (INCHES) }\end{array}$ \\
\hline 1 & 2.6 & 1.85 \\
2 & 8.2 & 5.88 \\
3 & 14.2 & 10.54 \\
4 & 22.6 & 16.28 \\
5 & 34.2 & 24.62 \\
6 & 65.8 & 47.38 \\
7 & 77.4 & 55.72 \\
8 & 85.4 & 61.46 \\
9 & 91.8 & 66.12 \\
10 & 97.4 & 70.15 \\
\hline
\end{tabular}
\end{tabular}

FIGURE C.12. B last Furnace \#4 Sampling Location 
CROSS SECTION OF DUCT

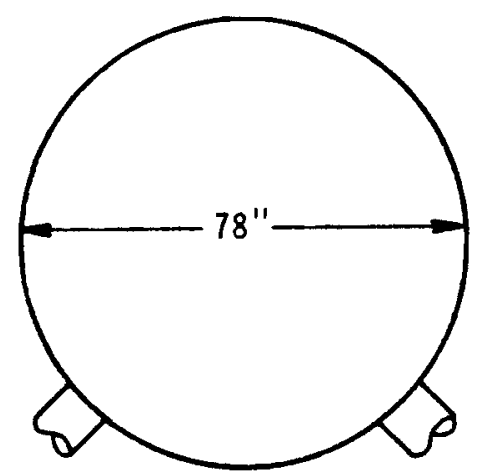

TRAVERSE POINT LOCATIONS

\begin{tabular}{|c|c|c|}
\hline $\begin{array}{c}\text { TRAVERSE } \\
\text { POINT NUMBER }\end{array}$ & $\begin{array}{c}\text { \% OF INSIDE } \\
\text { DIAMETER }\end{array}$ & $\begin{array}{c}\text { DISTANCE } \\
\text { FROM INSIDE } \\
\text { WALL (INCHES) }\end{array}$ \\
\hline 1 & 4.4 & 3.4 \\
2 & 14.6 & 11.4 \\
3 & 29.6 & 23.1 \\
4 & 70.4 & 54.9 \\
5 & 85.4 & 66.6 \\
6 & 95.6 & 74.6 \\
\hline
\end{tabular}

FIGURE C.13. BOP II Sampling Location

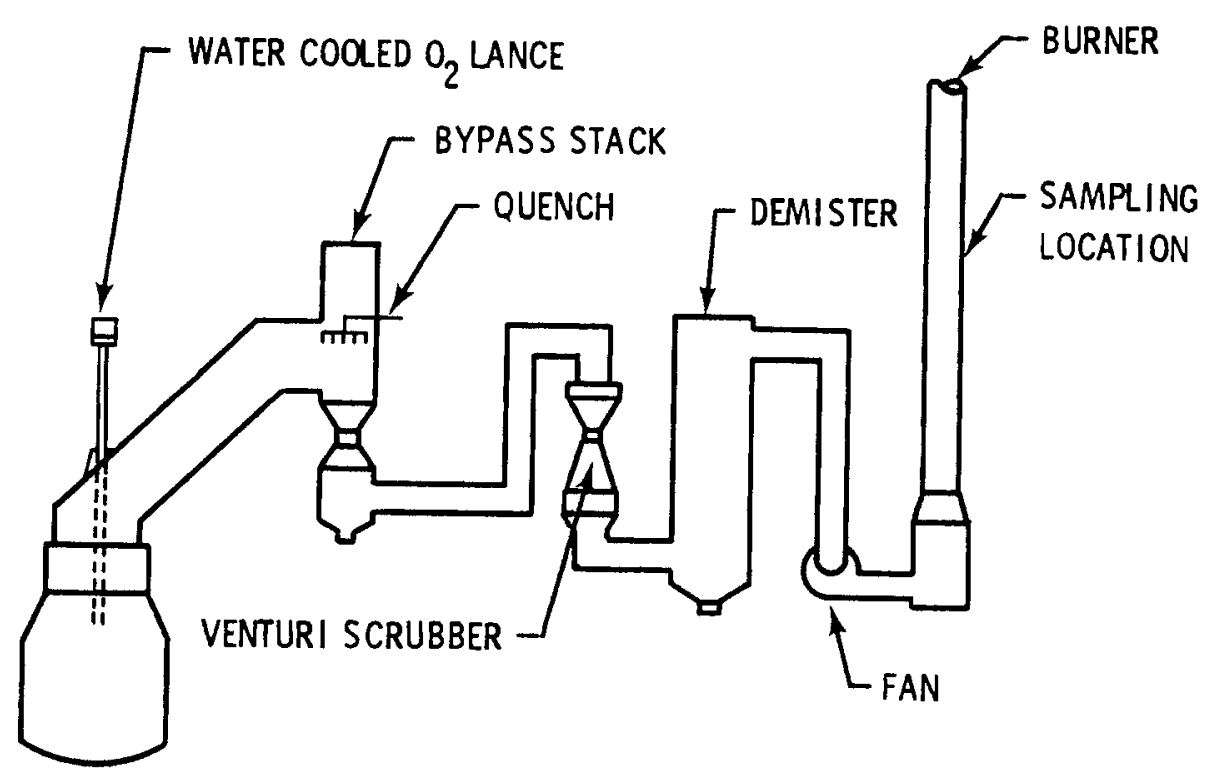

FIGURE C.14. BOP II Furnace Gas Ducting Schematic 


\section{SAMPLING AND ANALYSIS PROCEDURES}

\section{PARTICULATE SAMPLING}

Particulate sampling was performed according to EPA Method 5 (as revised August 10, 1977). The sampling train varied from the usual Method 5 train in that a flexible teflon line was used between the probe and the filter holder. Figure C.15 is a diagram of the sampling train.

The front half of the sampling train consisted of a calibrated nozzle, glass probe liner, flexible teflon line, and heated Whatman Cellulose fiber filter. Filterable particulates were collected in the front half of the sampling train.

The back half of the sampling train consisted of four glass impingers in series kept in an ice bath. The first, third and fourth impingers were modified Greenburg-Smith design, with the tip replaced with a 1/2-in.-I.D. glass tube extending to $1 / 2 \mathrm{in}$. of the bottom of the flask. The second impinger was the Greenburg-Smith type. The first and second impingers contained $200 \mathrm{ml}$ of distilled water, the third impinger was empty, and the fourth impinger contained $250 \mathrm{~g}$ silica gel. The impingers collectd moisture and other gas constituents condensing at $32^{\circ} \mathrm{F}$.

Before sampling, a velocity traverse was done at each sampling location to determine the average temperature and velocity. These data were used for nozzle size selection and adjustment of ncmographs for isokinetic sampling.

After assembling the sampling train, it was leak checked at 15 in. of mercury vacuum and sampling was not begun until a leak rate of less than $0.02 \mathrm{cfm}$ was achieved. Leak checks were done before each traverse change, and at the end of each test run at the maximum vacuum encountered during each portion of the tests.

The large amount of entrained water droplets in the gas stream at the basic oxygen furnaces resulted in a modification of the sampling train for one test. For the particulate test at furnace \#5 the filter was moved from before the impingers to after the third impinger. This successfully allowed the water to be removed so that it did not clog the filter. 


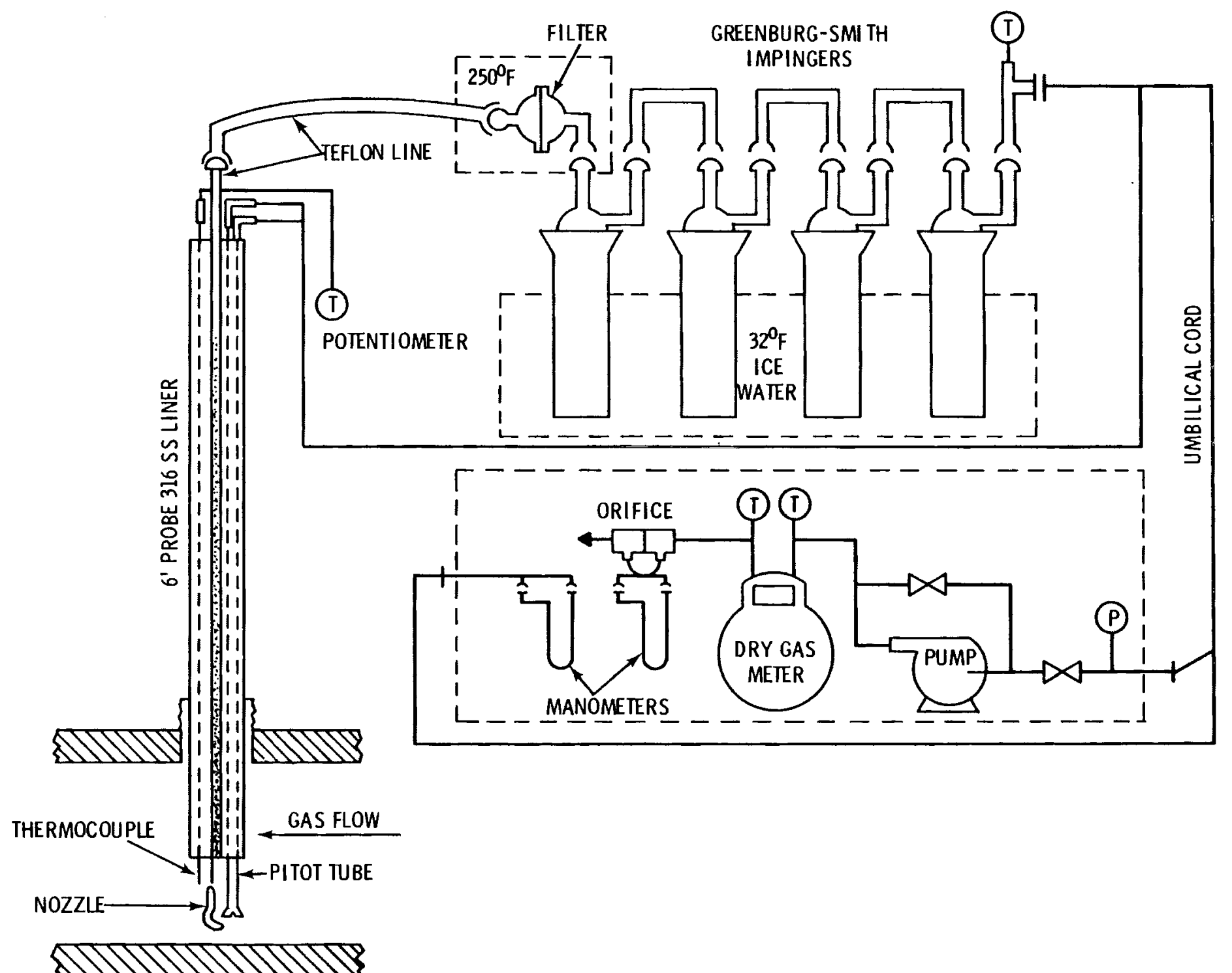

FIGURE C.15. Modified EPA Sampling Train 
SAMPLE RECOVERY

The sampling nozzle, probe liner, flexible line, and front half of the filter holder were rinsed with acetone and brushed with a nylon probe brush with a polypropylene handle. This acetone rinse was placed in a 250-ml nalgene bottle. The particulate filter was removed from the filter holder and placed in a sealed polyethylene jar.

The impinger solutions were measured and placed in glass sample containers. The acetone rinse of the impingers, back half of the filter holder, and connecting glassware were placed in a separate glass sample container with a teflon lid liner.

The front half acetone rinses were placed in tared beakers and evaporated. The impinger solutions were placed in tared beakers and dried on a steam bath. The filters and beakers were then placed in a dessicator until they reached a constant weight; they were then weighed to within a tenth of a milligram.

After the front half rinses and filters had been weighed to determine the amount of filterable particulate collected, the particulates in the beakers were redissolved with $100 \mathrm{ml}$ of $80 \%$ isopropanol. The filter for each test was then added to this solution, and macerated to dissolve sulfate collected on it. The resultant solution was then filtered and titrated with standardized barium perchlorate against thorin indicator to determine the amount of sulfate collected

\section{PARTICLE SIZING}

The size distribution of the particulates was determined with an Anderson 2000 impactor. This impactor has eight stages that separate the particulates into discrete size ranges. The particulates are inertially impacted upon the tared substrates in each stage by accelerating the gas stream through progressively smaller holes at each stage. Thus the larger particles are removed at the front of the impactor, and the smallest particles are removed at the back of the impactor.

The impactor was secured to the end of the sampling probe and the sample taken isokinectically as with the Method 5 sample. At the blast furnace 
location, the impactor would not fit through the gate valve on the duct. At these locations an extension of stainless steel tubing was placed on the impactor so that the sample could be taken with the impactor outside the duct.

After the test the filter substrates from each impactor stage were recovered into individual petri dishes. The calibrated nozzle and probe extension were rinsed with acetone and the rinse was placed in a separate sample container.

The sample was transported to the laboratory where the filter substrates were dessicated until they reached a constant weight and then were weighed to $0.1 \mathrm{mg}$. The probe extension and nozzle rinse were evaporated, dessicated and weighed in a tared beaker. The weight of the rinse was included with the weight collected on the first stage.

After the weight of particulates collected on stage had been determined, the percentage of the total particulate on each stage was calculated.

The particle size cutoffs were determined from the flow through the impactor and temperature of the stack gas. The cumulative percentages of particles in each size range were then plotted on log normal graph papers. The best fit straight line indicates the particle size distribution.

HYDROCARBONS $\left(\mathrm{C}_{1}-\mathrm{C}_{6}\right)$

Samples of the flue gas for hydrocarbon analysis were injected into the gas chromatograph with flame ionization detector with a 1-ml gas tight syringe. The sample entered a 2-m-long, 4-mm-1.D. glass column packed with 80/100 mesh Porapak Q. The column was in an oven with linear temperature program which went from $120^{\circ} \mathrm{C}$ to $160^{\circ} \mathrm{C}$ at $3^{\circ} \mathrm{C}$ per minute. This column allowed excellent separation of all isonumeric hydrocarbons up to butane.

A second sample was injected into a 2-m-long, 4-mm-I.D. glass column packed with OV-101 maintained at $120^{\circ} \mathrm{C}$. This provided a screen for higher hydrocarbons or more oxidized hydrocarbons.

Methane, ethane, and propane were found in most of the samples using the Porapack-Q Column. 
The distilled water impinger solutions from the particle sizing tests and furnace \#6 of the basic oxygen plant were extracted with methylene chloride to determine the presence of hydrocarbons. The concentration of methanol in the gas stream from furnace \#6 was also quantified from an integrated bag sample taken during a heat (see Table C.2) and is, therefore, a more reliable determination than the extraction of the condensate.

MAJOR GASES $\left(\mathrm{CO}, \mathrm{CO}_{2}, \underline{\mathrm{N}}_{2}, \underline{\mathrm{H}}_{2}\right)$

Sample gas from the blast furnace was pumped continuously through a filter, a silica gel drying column, and a 1-ml sampling loop at a rate of $6 \mathrm{~L}$ per minute. The sample was injected into the gas chromatograph by closing the sample loop inlet valve, allowing the pressure to equilibrate, closing the outlet valve, and then flushing the sample into the column with helium carrier gas. The sample first entered a Chromosorb 107 column $2 \mathrm{~m}$ in length maintained at a temperature of $140^{\circ} \mathrm{C}$. This column separated $\mathrm{CO}_{2}$ from the other gas constituents. After eluting from the first thermal conductivity detector, the sample entered a 3.2-m-long column containing molecular sieve 5A. This second column separated $\mathrm{H}_{2}, \mathrm{O}_{2}, \mathrm{~N}_{2}$, and $\mathrm{CO}$ and irreversibly abosorbed the $\mathrm{CO}_{2}$. With a carrier gas flow rate of $55 \mathrm{ml}$ per minute, the complete elution of all the components was accomplished in 8.5 min with complete resolution of all major gas constituents.

Samples at the blast furnaces were taken every 10 min for $4.5 \mathrm{~h}$ on each of two days at blast furnace \#4, and for $6 \mathrm{~h}$ on each of two days at blast furnace \#3.

Since it was not possible to run a sample line to the basic oxygen furnace stack, as had been done at the blast furnaces, it was necessary to take grab samples of the gas at these locations. In order to fully characterize the changes in gas composition during each heat at the basic oxygen furnaces, a series of 11 integrated bag samples were take over the cycle. The heat cycle commenced with the lowering of the oxygen lance and continued for $17 \mathrm{~min}$. Table $C .8$ shows the time sequence in which these samples were taken during each heat. 


\section{TABLE C.8. Timing Interval of Bag Samples Taken}

During BOP Heat Cycle

\begin{tabular}{cc}
$\begin{array}{c}\text { Bag } \\
\text { Number }\end{array}$ & $\begin{array}{c}\text { Time } \\
\text { Interval }\end{array}$ \\
\cline { 3 - 3 } 1 & $0-2 \mathrm{~min}$. \\
2 & $2-3 \mathrm{~min}$. \\
3 & $3-4 \mathrm{~min}$. \\
4 & $4-6 \mathrm{~min}$. \\
5 & $6-8 \mathrm{~min}$. \\
6 & $8-10 \mathrm{~min}$. \\
7 & $10-12 \mathrm{~min}$. \\
8 & $12-13 \mathrm{~min}$. \\
9 & $13-14 \mathrm{~min}$. \\
10 & $14-15 \mathrm{~min}$. \\
11 & $15-17 \mathrm{~min}$.
\end{tabular}

(a) Timing began with the lowering of the oxygen lance into the BOF

Immediately after the termination of the heat, the bags were taken to the mobile laboratory and analyzed by the method described above. All calibration was accomplished using external standardization with certified standards $( \pm 2 \%)$ and sample concentrations were calculated from peak height using the equation:

$$
\text { sample concentration }=\frac{\text { (peak height of sample }(\mathrm{mm})) \text { (standard concentration) }}{\text { peak height of standard (mm) }}
$$

\section{MINOR GASES}

Sulfur Dioxide

Sulfur dioxide samples were taken according to EPA Method 6. The sample was drawn through four midget impingers in series in an ice bath. The first impinger contained $20 \mathrm{ml}$ of $80 \%$ isopropanol to capture $\mathrm{SO}_{3}$ and a glass wool filter to prevent droplet carry over. The second and third impingers contained 
approximately $15 \mathrm{~g}$ of silica gel to remove moisture going to the dry gas meter. Figure C.16 is a diagram of the midget impinger sampling train used for minor gases.

The sample was drawn at a rate of 4 to $11 \mathrm{ft}^{3} / \mathrm{h}$ for a 30 -min period. After the sample was taken, the sampling train was purged with ambient air for 5 min to displace any $\mathrm{SO}_{2}$ remaining in the isopropanol impinger into the hydrogen peroxide impingers.

The samples were analyzed for sulfur dioxide by taking an aliquot of the hydrogen peroxide impinger solution and titrating with barium perchlorate solution and thorin indicator.

NO $x$ Sampling

Sampling for oxides of nitrogen in the gas stream was done in accordance with EPA Method 7. This method entails grab sampling of the flue gas with an evacuated flask containing a measured volume of absorbent solution. The absorbent solution is hydrogen peroxide acidified with sulfuric acid which oxidizes $\mathrm{NO}$ and $\mathrm{NO}_{2}$ to $\mathrm{NO}_{3}$. Figure $\mathrm{C} .17$ is a diagram of the Method 7 sampling apparatus.

Before each sample was taken $25 \mathrm{ml}$ of absorbent solution were pipetted into the flask. The flask was then evacuated to less than 4 in. of mercury absolute pressure. The temperature and pressure of the flask and the barometric pressure were noted, and the flask was allowed to sit for a few moments before checking the vacuum again to assure that it did not leak.

To take the sample, the flask was attached to a 4-ft long stainless stee 1 probe having a glass wool filter. A squeeze bulb was attached to the three-way valve and the valve was placed in the "purge" position. The probe was purged with flue gas before switching the valve to the "sample" position. The valve was left in the "sample" position for $30 \mathrm{~s}$ to assure that the flask pressure had reached an equilibrium with that of the duct. After taking the sample, the valve was closed; the flask was shaken for $5 \mathrm{~min}$ and allowed to set for $16 \mathrm{~h}$.

The sample was recovered by measuring the final flask pressure and temperature, placing the absorbent solution in a plastic bottle, rinsing the 


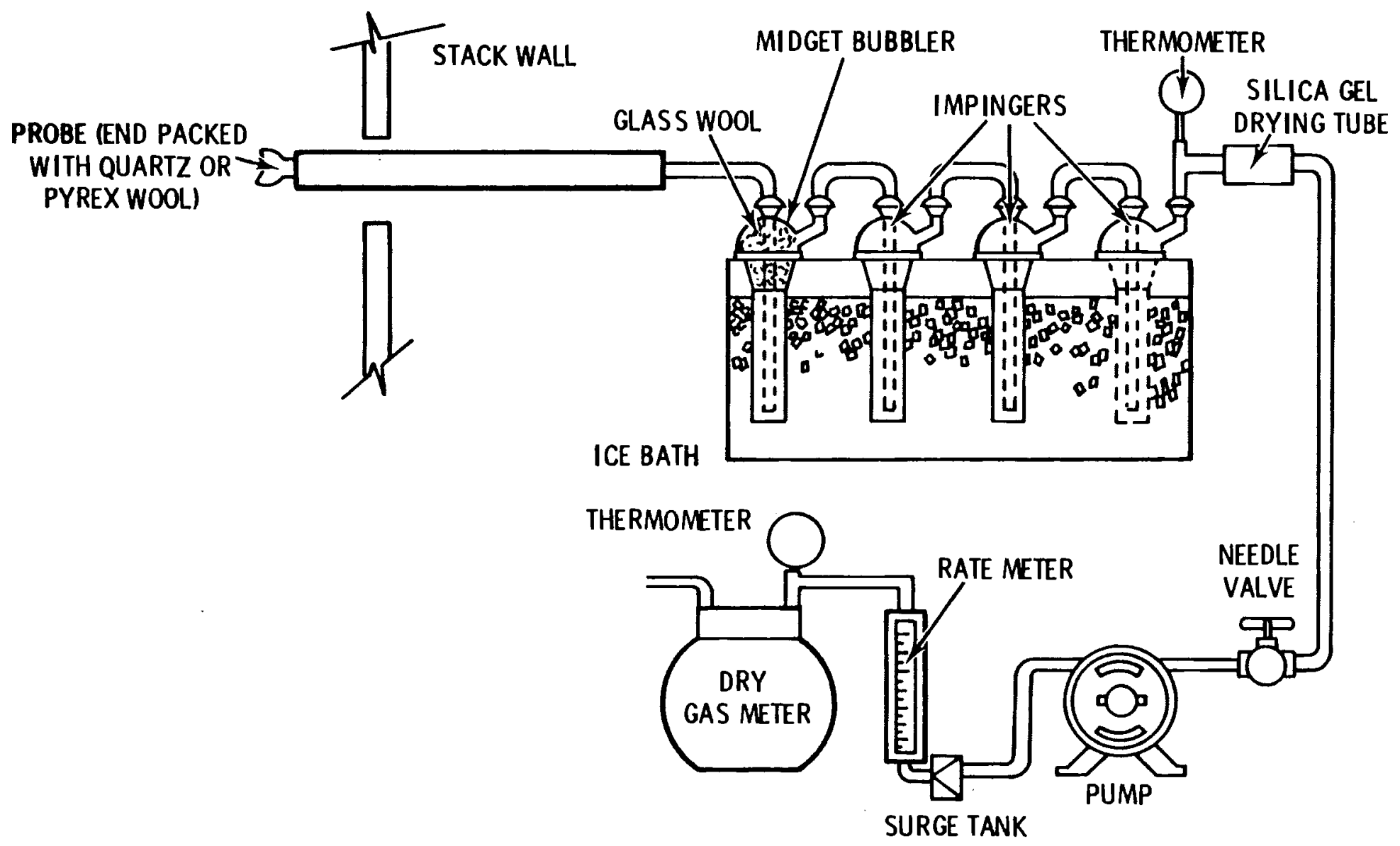

FIGURE C.16. EPA Method 6 Surlfur Dioxide Sampling Train 


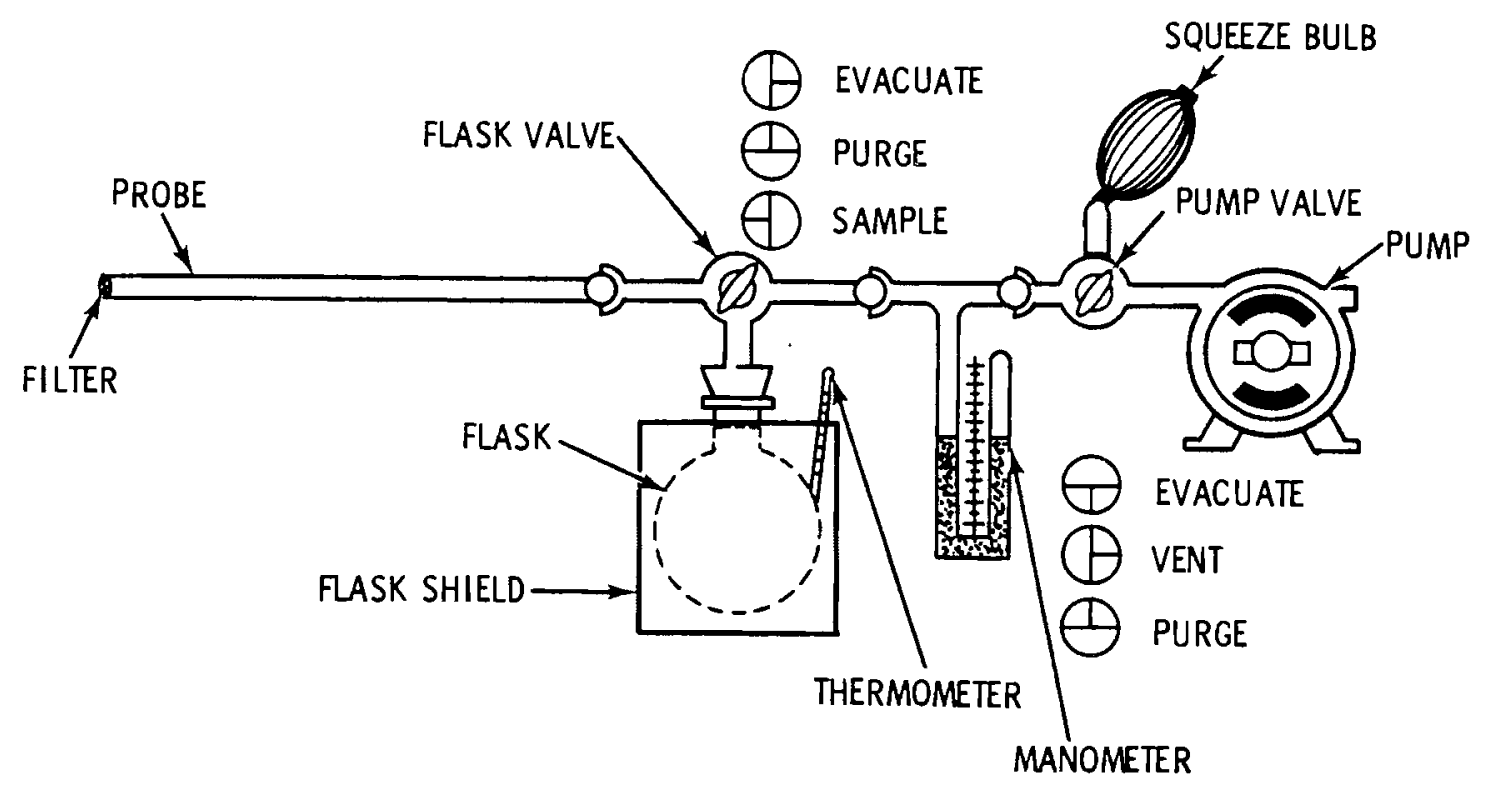

FIGURE C.17. Method 7 Sampling Train

flask with distilled water, and neutralizing the acid solution with sodium hydroxide. The plastic containers were labelled, inventoried, sealed, and returned to TRW's Redondo Beach laboratory for analysis.

ANALYSIS

The sample was transferred to a $50-\mathrm{ml}$ volumetric flask, rinses of the container were added, and the solution was brought to volume with deionized water. A $25-\mathrm{ml}$ aliquot of the sample solution was pipetted into a beaker and evaporated on a steam bath. A 2-ml portion of phenoldisulfonic acid solution was added to the residue and mixed thoroughly. To this mixture $1 \mathrm{ml}$ of deionized water and four drops of concentrated sulfuric acid were added. This solution was heated on a steam bath for 3 min while stirring. After the solution had cooled, $20 \mathrm{ml}$ of deionized water were added, and the solution was brought to $\mathrm{pH}$ of 10 by the addition of concentrated ammonium hydroxide. The solution was then filtered through Whatman No. 41 filter paper into a 100-ml volumetric flask which was brought up to volume with deionized water. The absorptance of this solution was measured with a Spectronic 70 spectrophotometer and compared with a calibration curve of absorptances for standard concentrations of $\mathrm{KNO}_{3}$. 


\section{REDUCED SULFUR GASES $\left(\mathrm{H}_{2}, \mathrm{COS}, \mathrm{CS}_{2}\right)$}

These gases were collected in a sampling train consisting of four midget impingers. The first two impingers contained $20 \mathrm{ml}$ each of a $4.1 \%$ solution of $\mathrm{CdSO}_{4}$ in dilute $\mathrm{NaOH}$. The sulfide in the gas stream is precipitated as CdS, an insoluble yellow precipitate. The solution is analyzed by dissolving the precipitate in $\mathrm{HCL}$, reacting it with a standard iodine solution, and back titrating it with a standard sodium thiosulfate solution to determine the amount of iodine consumed by the liberated $\mathrm{H}_{2} \mathrm{~S}$.

The third impinger of the sampling train contained $20 \mathrm{ml}$ of $7.5 \% \mathrm{CaCl}_{2}$ in $1 \% \mathrm{NH}_{4} \mathrm{OH}$. The absorbed $\mathrm{COS}$ is removed from the solution for analysis by adding $\mathrm{H}_{2} \mathrm{O}_{2}$ which oxidizes the $\mathrm{COS}$ to $\mathrm{CO}_{2}$ and $\mathrm{SO}_{4}$. The sulfate is precipitated with $\mathrm{a} \mathrm{BaCl}_{2}$ solution which is then filtered and ignited at $900^{\circ} \mathrm{C}$. The amount of sulfate is determined gravimetrically.

The last impinger contained $20 \mathrm{ml}$ of alcoholic $\mathrm{KOH} . \mathrm{CS}_{2}$, which is not soluble in the first two impinger solutions, was absorbed in this last impinger. The sample was processed and analyzed by the same procedure used for $\cos$.

The impingers were placed in an ice bath, and flue gas was drawn through them at a rate of $4 \mathrm{cfh}$ for $30 \mathrm{~min}$. The sample volume was measured with a calibrated dry gas meter, and the sample gas temperature was monitored with a bimetal thermometer so that sample volumes could be reduced to standard conditions $\left(20^{\circ} \mathrm{C}\right.$ and 29.97 in $\left.\mathrm{Hg}\right)$.

PHOSPHINE $\left(\mathrm{PH}_{3}\right)$

Initially phosphine was to be sampled by drawing flue gas through an 18-cm $\times 0.5-\mathrm{cm}$ I.D. glass tube filled with chromatographic-grade silica gel impregnated with $\mathrm{AgNO}_{3}$. The phosphine reacts with the $\mathrm{AgNO}_{3}$ as follows:

$$
3 \mathrm{Ag}+3 \mathrm{NO}_{3}+\mathrm{PH}_{3} \rightarrow \mathrm{Ag}_{3} \mathrm{P}+3 \mathrm{HNO}_{3}
$$

The $\mathrm{Ag}_{3} \mathrm{P}$ is a black precipitate that forms a dark front moving along the tube. However, due to the chemically reduced flue gas, the silver nitrate was 
reduced to silver metal, possibly by reduction by hydrogen in the flue gas. The method was subsequently replaced by an impinger train consisting of two impingers containing $20 \mathrm{ml}$ each of $0.1 \mathrm{~N} \mathrm{AgNO}_{3}$ solution. The sample was analyzed by oxidizing the sample with $\mathrm{H}_{2} \mathrm{O}_{2}$ and saturated bromine water and analyzing for phosphate. Laboratory tests showed this method to be $72 \%$ efficient for the removal of $\mathrm{PH}_{3}$ at the $10 \mathrm{ppm}$ level.

\section{CYANIDE ( $\mathrm{HCN}$ ) AND AMMONIA $\left(\mathrm{NH}_{3} \mathrm{~L}\right.$}

A midget impinger train consisting of four impingers in series was used to collect these gases. The first two impingers contained $20 \mathrm{ml}$ each of $1.0 \mathrm{~N} \mathrm{NaOH}$ to absorb HCN gas. The last two impingers contained $20 \mathrm{ml}$ each of $3.0 \mathrm{~N} \mathrm{HCL}$ to absorb ammonia.

The first two impinger solutions were analyzed by reacting the solution with barbituric acid and chloramine-T to produce a colored complex. The absorbance of the solution was measured spectrophotometrically to determine the cyanide concentrations. The last two impingers were analyzed by nesslerization of the $\mathrm{HCl}$ absorbing solution to determine the concentration of ammonia.

HALOGEN GASES ( $\left.\mathrm{I}_{2}, \mathrm{Br}_{2}, \mathrm{Cl}_{2}\right)$

The flue gas was drawn through two impingers containing $20 \mathrm{ml}$ each of $0.0125 \mathrm{~N} \mathrm{NaOH}$ solution. The absorbed iodine was analyzed by UV spectrophotometry as $I_{3}^{-}$. The bromine was determined by brominating phenol red and spectrophometric analysis. Chlorine was determined by reacting the solution with 0-Tolidine which forms a colored complex with halogens. Laboratory tests showed a $92 \%$ capture efficiency of the method for iodine.

\section{METALS}

Filters and probe rinse residues were dry ashed in a muffle furnace at $600^{\circ} \mathrm{C}$ for $2 \mathrm{~h}$. The ash from the filters were transfered quantitatively to $150-\mathrm{ml}$ beakers and digested in a 3:3:1 mixture of water, $\mathrm{HNO}_{3}$, and $\mathrm{HCl}$. The ash from the probe residue was weighed and a weighed amount was removed and digested by the same method. The samples were taken to dryness and the residue 
was redissolved in $0.1 \mathrm{~N} \mathrm{HNO}_{3}$, filtered through whatman \#41, and brought to volume with washing in a $50-\mathrm{ml}$ volumetric flask. The solution was then analyzed by atomic absorption spectrophotometry. 


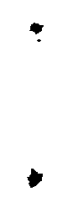




\section{DISTRIBUTION}

No. of

Copies

$\underline{\text { OFFSITE }}$

A. A. Churm

DOE Patent Division

9800 S. Cass Avenue

Argonne, IL 60439

2 Raymond D. Cilimberg

DOE Office of Industrial Programs CS 122.2

Forrestal Bldg.

Washington DC 20585

Dr. J. F. Collins

DOE Office of Industrial Programs CS 121.2

Forrestal Bldg.

Washington, DC 20585

2 Bruce Cranford

DOE Office of Industrial Programs CS 121.2

Forrestal Bldg.

Washington, DC 20585

27 DOE Technical Information Center

Brian Rogers

Air Products and Chemicals, Inc.

1260 N. Borauga, Suite 210

Houston, TX 77067

E. P. Lynch

Energy, Environmental Systems

Division

Argonne National Laboratory

Building 12

Argonne, IL 60439
No. of

Copies

John Varga, Jr.

Materials Resources and Process Metallurgy Section

Battelle Columbus Laboratories

505 King Avenue

Columbus, $\mathrm{OH} 43201$

M. H. Heisterberg

GATX Tank Erection Company

120 S. Riverside Plaza

Chicago, IL 60606

M. 0. Holowaty

In land Stee 1 Company

Research Laboratories

3001 E. Columbus Drive

East Chicago, IN 46312

S. P. Vitt

Kaiser Steel Corporation

Steel Manufacturing Division

P.0. Box 217

Fontana, CA 92335

J. Trautwe in

Liquid Carbonic Corp.

135 S. La Salle

Chicago, IL 60603

H. M. McKelvy

Monsanto Company

800 N. Lindbergh Boulevard

St. Louis, M0 63166

L. C. Beale, Jr.

National Steel Corporation

Research Center

Weirton, WV 26062 
No. of

Copies

E. I. Wan

Science Applications, Inc.

1710 Goodridge Drive

McLean, VA 22102

D. J. Haase

Tenneco Chemicals

P.0. Box 849

Pasadena, TX 77501

Delbert Powell

Energy Systems Group of

TRW Inc.

One Space Park

Redondo Beach, CA 90278

J. L. Heck

Union Carbide Corporation

Linde Division

100 0ceangate

P.0. Box 340

Long Beach, CA 90802

K. A. Schowalter

United States Steel Corporation

Research Laboratory

125 Jameson Lane

Monroeville, PA 15146

\section{FORE IGN}

M. Thiensuthikul

3E Machinery Supply Limited

Partnership

3111 Ladyar Road

Bangkok 6, Tha $i l$ and

Fernand Charest

Gouvernement du Quebec

Ministere de L'Industrie du Commerce

Direction Generale de

L'Industrie

1, Place Ville-Marie, 23e etage

Montrea1, Que. H3B3M6
No. of

Copies

ONSITE

DOE Richland Operations Office

H. E. Ransom

36 Pacific Northwest Laboratory

E. G. Baker

C. M. Devary

D. C. Elliot

S. E. Lyke (20)

P. M. Molton

R. H. Moore

R. E. Nightingale

C. A. Rohrmann

G. F. Schiefelbein

P. C. Walkup

Publishing Coordination (2)

Technical Information YO (5) 